DEPARTMENT OF THE INTERIOR

UNITED STATES GEOLOGICAL SURVEY

GEORGE OTIS SMITH, DIRECTOR

\title{
GEOLOGY AND OIL RESOURCES
}

OF THE

\section{SUMMERLAND DISTRICT}

\author{
SANTA BARBARA COUNTY \\ CALIFORNIA
}

BY

\section{RALPH ARNOLD}

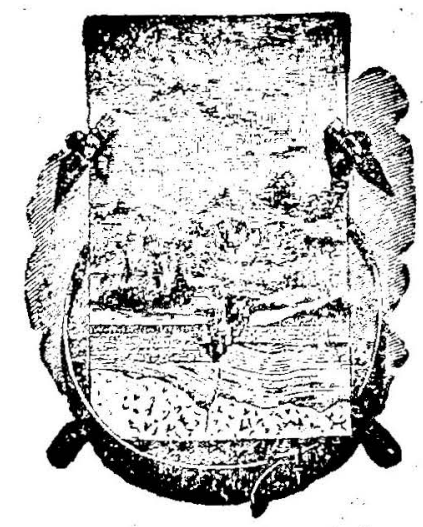

WASHI NGTON

GOVERNMENT PRINTING OFFIOE 1907 



DEPARTMENT OF THE INTERIOR

UNITED STATES GEOLOGICAL SURVEY

GEORGE OTIS SMITH, DIRECTOR

\title{
$\therefore \quad$ GEOLOGY AND 0IL RESOURCES
}

\section{OF THE \\ SUMMERLAND DISTRICT}

\author{
SANTA BARBARA COUNTY \\ CALIFORNIA
}

BY

RALPH ARNOLD

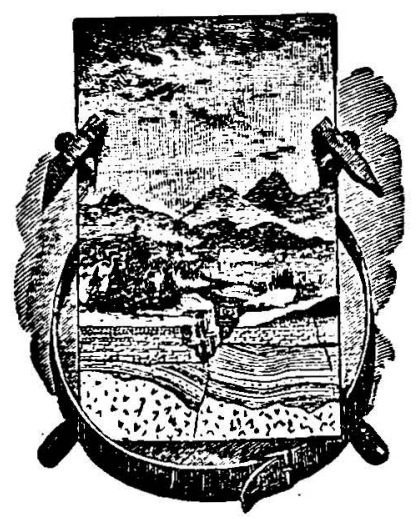

W A S H I N GTO N

GOVERNMENT PRLNTING OFFICE

$$
1907
$$

LIBRARY 935:32

TEÓAS IECHNOLOGICAL CQWLEGE

LUBBOCK, TEXAS 



\section{CONTENTS.}

Intmo.

Introduction.................................................. 7

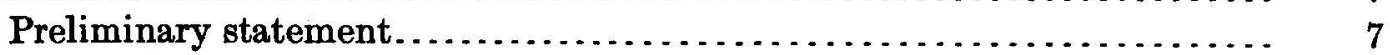

Acknowledgments ........................................ 8

Previous knowledge of the region. ............................. 8

Historical outline............................................ 16

Location.................................................. 17

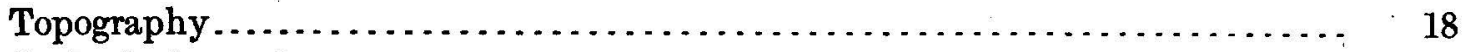

Geologic formations............................................. 21

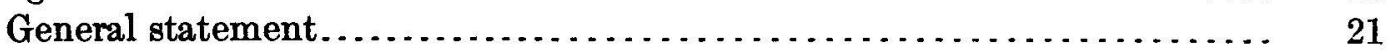

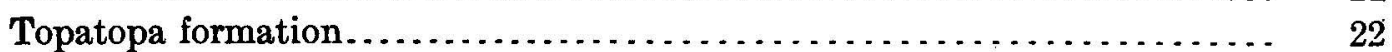

Name.................................................. 22

Lithologic character.................................... $\quad 22$

Age and fossils......................................... $\quad 23$

Distribution and structure............................... $\quad 23$

Evidences of petroleum............................... 23

Water from the Topatopa formation......................... 23

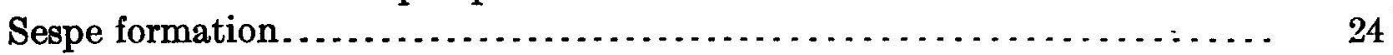

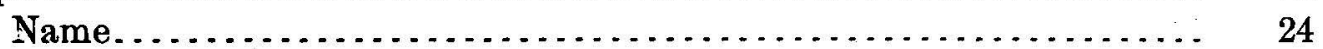

Lithologic character....................................... 24

Age.................................................. 25

Distribution and structure............................... 25

Evidences of petroleum................................ $\quad 26$

Vaqueros formation......................................... $\quad 26$

Name and correlation................................... 26

Lithologic character................................. $\quad 26$

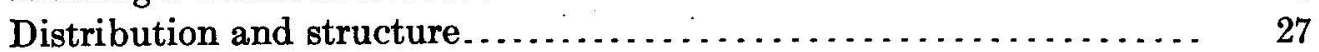

Monterey shale ............................................ 27

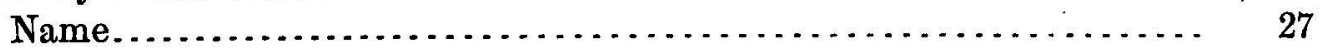

Lithologic character..................................... $\quad 27$

Age and fossils....................................... 28

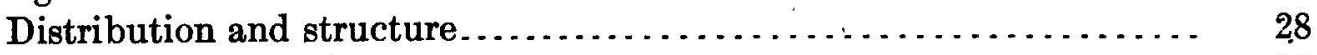

Evidences of petroleum................................ $\quad 29$

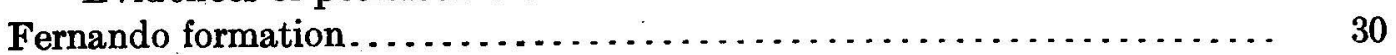

Name............................................. 30

Lithologic character in the Summerland area................. $\quad 30$

Lithologic character in the Santa Barbara area.................. 31

Age and fossils............................................ 31

Distribution and structure.............................. 32

Evidences of petroleum................................ 33

Pleistocene.............................................. 33

Lithologic character..................................... 34

Distribution......................................... 35

Evidences of petroleum.................................. 35 
Structure

General structure of the district. .......................... 36

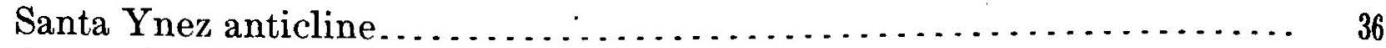

Arroyo Parida anticline and fault . . . . . . . . . . . . . . . . . . 36

Minor folds near the coast. . . . . . . . . . . . . . . . . . . . . . . . 37

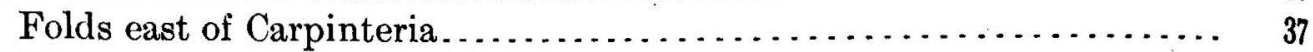

Flexures near Summerland . . . . . . . . . . . . . . . . . . . . . 37

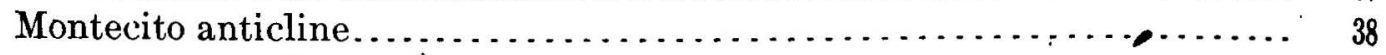

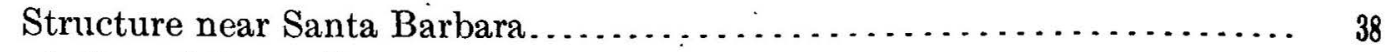

Description of the wells. . . . . . . . . . . . . . . . . . . . . . .

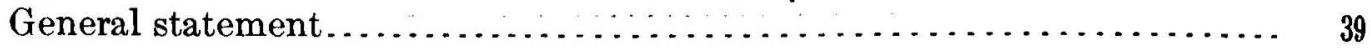

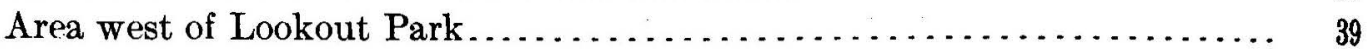

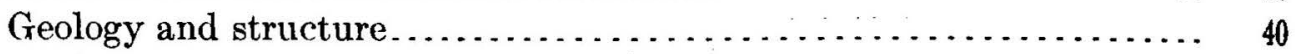

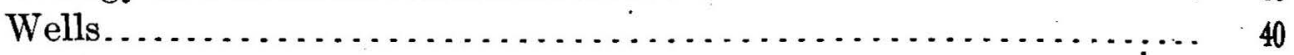

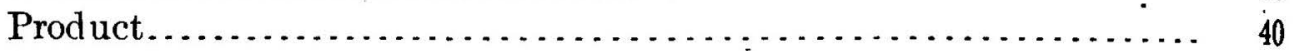

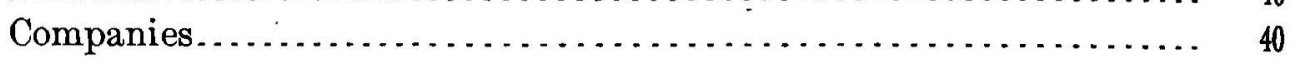

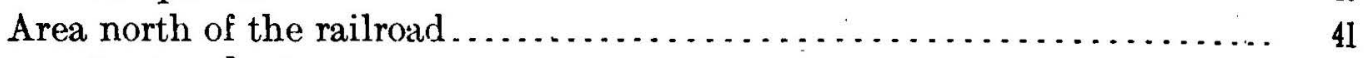

Geology and structure............................. 41

Wells......................................... 41

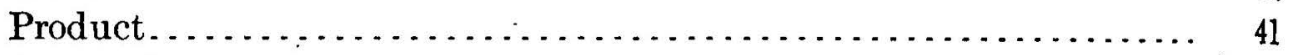

Companies......................................... ${ }_{41}$

Area between the railroad and the beach $\ldots \ldots \ldots \ldots \ldots \ldots \ldots \ldots \ldots .41$

Geology and structure............................ 41

Wells............................................ 42

Product. . . . . . . . . . . . . . . . . .

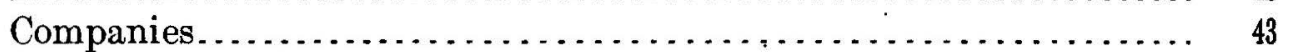

Beach and wharf wells . . . . . . . . . . . . . . . . . . . . . . . . 43

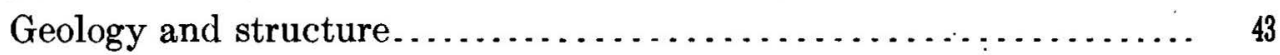

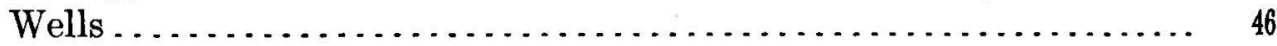

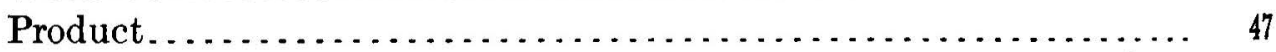

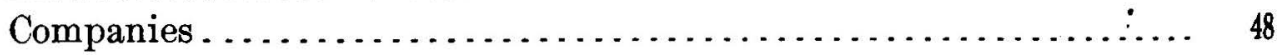

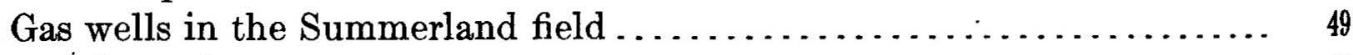

General statement .................................... 49

Geology and structure. . . . . . . . . . . . . . . . . . . . . . . 49

Production of the wells............................. 50

Summary of conclusions concerning the oil $\ldots \ldots \ldots \ldots \ldots \ldots \ldots \ldots \ldots \ldots$

Wells at other localities in the Summerland district $\ldots \ldots \ldots \ldots \ldots \ldots \ldots . \quad 52$

Wells near Loon Point. .............................. ${ }_{52}$

Wells near Carpinteria and Rincon Creek. . . . . . . . . . . . . . . 53

Wells in the mountains northeast of Summerland ............... 55

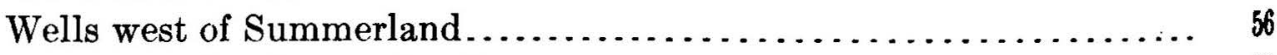

Conclusions concerning future development. $\ldots \ldots \ldots \ldots \ldots \ldots \ldots \ldots \ldots \ldots$

General statement . . . . . . . . . . . . . . . . . . . . . . . . . . . ${ }_{56}$

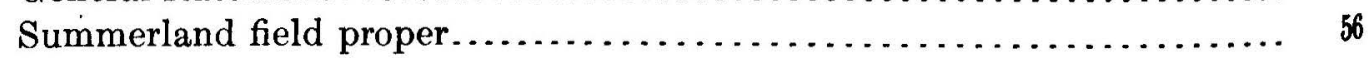

Region near Carpinteria................................. 57

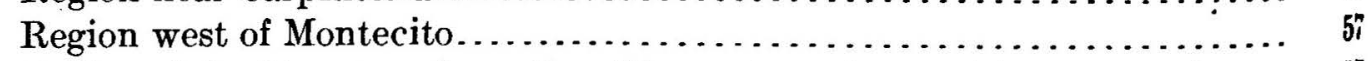

Region of the Topatopa formation (Eocene) northeast of Summerland..... 57

Physical and chemical properties of the oil $\ldots \ldots \ldots \ldots \ldots \ldots \ldots \ldots \ldots \ldots$

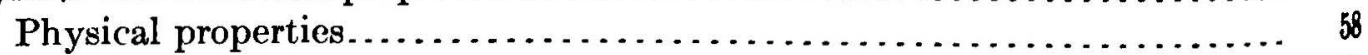

Color. . . . . . . . . . . . . . . . .

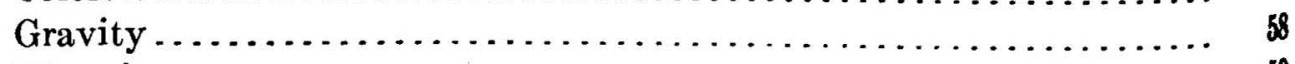

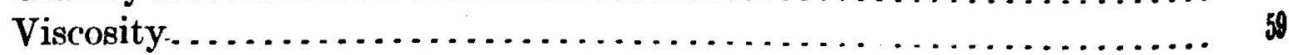


Physical and chemical properties of the oil-Continued.

Page.

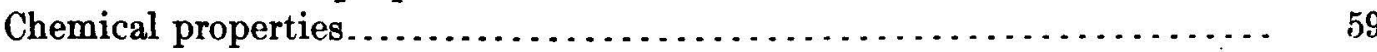

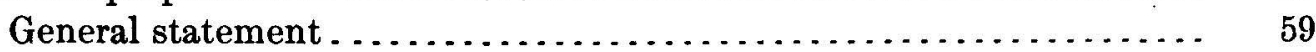

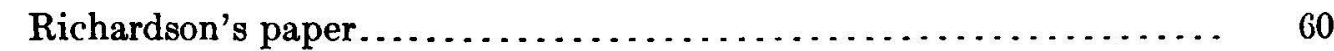

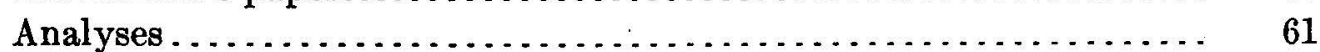

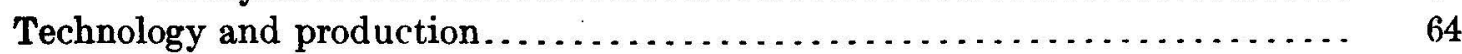

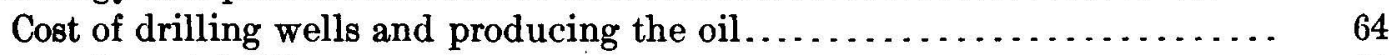

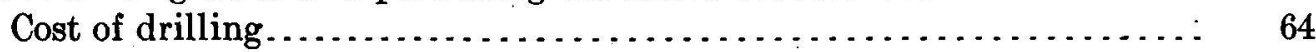

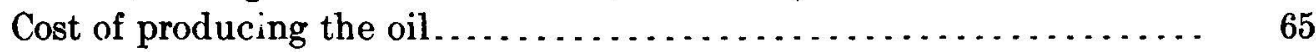

Separation of sand and water from oil.,$\ldots \ldots \ldots \ldots \ldots \ldots \ldots \ldots \ldots \ldots$

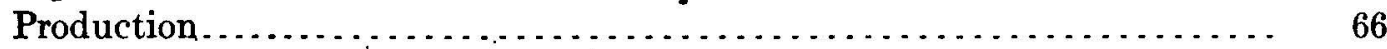

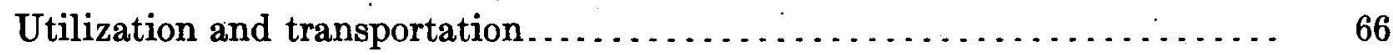

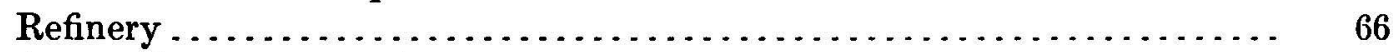

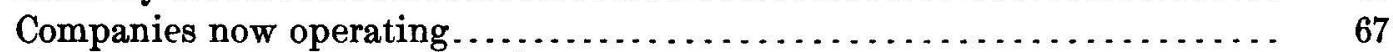

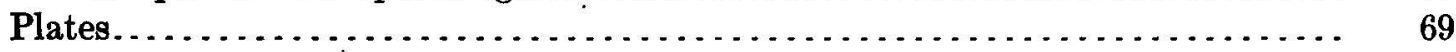

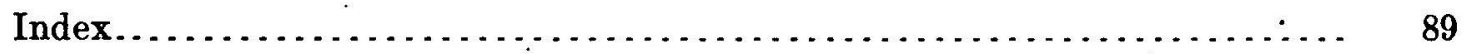

\section{ILLUSTRATIONS.}

Plate I. Geological and structural map cf the Summerland oil district......

II. $A$, Summerland oil fleld, looking south from Ortega Hill; $B$, Pleistocene beds in railroad cut west cf Summerland...............

III. $A$, Beach near Carpinteria asphalt mine, showing exuding tar; $B$, A tar volcano in the Carpinteria asphalt mine...............

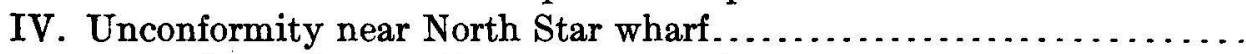

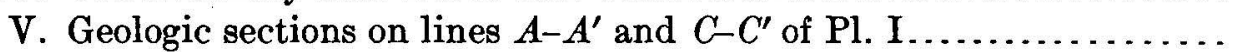

VI. Structure map of Summerland oil field.....................

VII. $A$, Geologic section on line $B-B^{\prime}$ of Pl. I; $B$, Section through Treadwell (Southern Pacific Company's) wells.

VIII. Sections showing relations of oil sands in various Summerland wells.

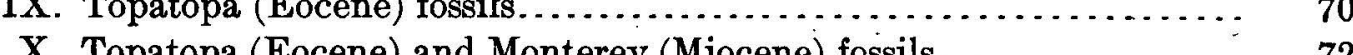

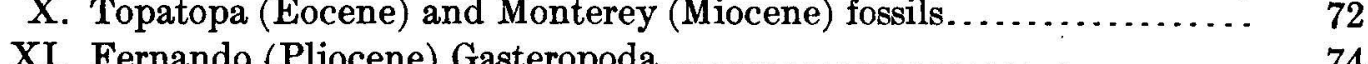

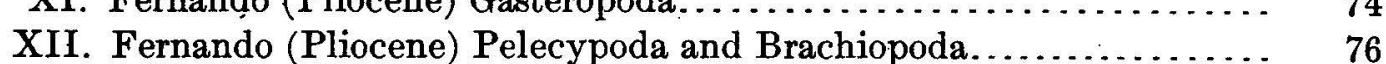

XIII. Fernando (Pliocene) Gasteropoda. . . . . . . . . . . . . . . . . . . 78

XIV. Fernando (Pliocene) Pelecypoda.......................... 80

XV. Fernando (Pliocene) Pecten . . . . . . . . . . . . . . . . . . . . 82

XVI. Fernando (Pliocene) Pecten . . . . . . . . . . . . . . . . . . . . . . . 84

XVII. Fernando (Pliocene) Bryozoa.......................... 86

Fig. 1. Index map showing location of California oil districts............. 18

2. Detailed section of bluff near North Star wharf ................. 34

3. Geologic sections through Lillis, Oxnard, and Sea Cliff wells . . . . . . 44 



\section{GEOLOGY AND OIL RESOURCES OF THE SUMMER- LAND DISTRICT, SANTA BARBARA COUNTY, CALIFORNIA.}

By Ralph Arnold.

\section{INTRODUCTION.}

PRELIMINARY STATEMENT.

One of the most novel and interesting sights along the coast of Santa Barbara County is that of the derricks marking the location of the oil wells which start down from wharves over the Pacific Ocean at Summerland. Mr. George H. Eldridge examined this territory in February and March, 1902, with the intention of incorporating a description of it in his contemplated exhaustive report on the California oil fields; but he died in June, 1905, before he had written anything concerning this field except a very brief note, which was published in Contributions to Economic Geology for 1902. ${ }^{a}$ Mr. Eldridge visited the field during the height of its development, and for this reason was able to obtain much valuable information concerning the geology of the wells which otherwise would have been lost. The writer has made free use of this information in the compilation of the contour map and the sections accompanying the present report.

During the summer of 1906 the writer spent two weeks in an examination of the Summerland field and a geologic survey of the contiguous region along the coast from Santa Barbara to Carpinteria and as far inland as the crest of the Santa Ynez Range. In the following pages the discussion of the geology is based almost entirely on the work of the writer. The data concerning the wells have been obtained largely from Mr. Eldridge's notebooks.

So far as the development of the present producing sands is concerned, the Summerland field has undoubtedly passed its acme. However, so much that is of service in drawing conclusions about less well-developed fields is to be learned from a study of a fully 
exploited territory like this that it has been deemed expedient to prepare the present more or less detailed report.

A brief summary of the previous knowledge of the region, followed by a fairly full description of its topography and geology, introduces the detailed discussion of the geology of the wells and conclusions concerning future development. This portion of the report is followed by sections devoted to a discussion of the properties of the oil, a statement of production, and data concerned with the technology of the industry. The descriptions of the geology and structure are elucidated by photographic views, drawings, and maps, and plates showing the abundant or characteristic fossils of the various formar tions supplement the lists in the text.

\section{ACKNOWLEDGMENTS.}

To Mr. George H. Eldridge the writer is under the greatest obligation for the free use that has been made of notes and ideas concerning the occurrence of the petroleum. Where sections or direct statements are copied from his notebooks, the fact has been so recorded. The thanks of Mr. Eldridge to those who furnished him with information would certainly have been recorded in his report had he lived to write it, and the present writer feels that he is doing only what his predecessor would have done in recording the names of those to whom, as indicated by his notes, he was indebted. These are Messrs. Snow, of the Occidental Mining and Improvement Company; J. B. Treadwell; G. F. Becker; J. C. Lillis, of the Lillis Oil Company; Thomas D. Wood and R. A. Phelps, of the Duquesne Oil Company; J. E. Sloan, of the North Star Oil Company; J. W. Darling; C. C. Newman, of the Sea Cliff and Oxnard oil companies; W. L. Rust, of the Sea Side Oil Company; C. W. Robinson; G. W. Woodruff; J. H. Lundberg; B. N: Coffman, of the Marine Oil Company; J. F. Miller; A. C. Doane; and presumably several others whose names do not appear. In addition to those mentioned the writer wishes to acknowledge his indebtedness to Messrs. J. F. Goodwin, of the Pinal Oil Company; W. D. Morgan, of the G. F. Becker Oil Company; E. G. Ludlam, manager of the Southern Pacific Company's wells; A. Sattler, manager of the Columbia Oil and Asphalt Company of Carpinteria; F. F. Fluornoy, county surveyor; and Dr. Lorenzo G. Yates, of Santa Barbara. Dr. R. S. Bassler, of the United States National Museum, kindly prepared the plate and explanations of the commoner species of Bryozoa found in the Fernando (Pliocene) beds of the district.

\section{PREVIOUS KNOWLEDGE OF THE REGION.}

Several geologists have at one time or another visited the region under discussion, and in the following paragraphs the writer has attempted to give a résumé of the notes recorded by these men. 
Those statements which relate to localities in this region not visited by the writer, or which are in publications inaccessible to most readers, are copied more or less in detail. A more complete bibliography of the literature referring to the geology of the southern coast ranges and the oil industry in California will be found in Bulletin No. 309 of the United States Geological Survey, pages 199-202. The following references are arrranged chronologically:

1853. Blake, W. P., Report of a reconnaissance and survey in California, in $1853 .{ }^{a}$ So far as the writer is aware, W. P. Blake, one of the geologists of the Pacific Railroad survey, was the first to give any notes concerning the geology of the region about Santa Barbara. According to Antisell, $b$ Blake, in describing the Santa Ynez Range, "puts forth the view that all of these strata from Point Arguello eastward have been elevated by the mass of granite forming the San Bernardino Mountains, whose influence he believes to spread thus far to the west, and also to have produced the lone hills of the desert and basin upon the east."

1855. Trask, J. B., Report on the geology of the Coast Mountains, etc. ${ }^{c}$ Trask, first State geologist of California, was the next writer to describe the Santa Barbara country, and he, too, adopted the same view of the origin of the Santa Ynez Range as Blake, and even went so far as to include the range under the name "San Bernardino Moun"tains."

1857. Antisell, Thomas, Santa Barbara Mountains. ${ }^{d}$ Antisell, in his description of the geology of the Santa Barbara Mountains, was the first to call attention to what is believed by the writer to be one of the most important points regarding them. He says: ${ }^{e}$

Between the disposition of the Sierra Santa Ynez and that of the more easterly coast ranges there is this difference-that while the other ranges are disposed so by virtue of their axial forces running along the direction of that range, the Santa Ynez Mountains are ridges en échelon, interlocking with each other, and running from east to west.

This statement is true more particularly for the western portion of the range, physiographic and structural axes being approximately coincident in that part immediately back of Summerland.

Antisell doubtless was mistaken as to the origin of one or two of the rocks he describes, but in the main his descriptions of both the igneous and the sedimentary rocks of the range are correct. The most interesting part of his report, from the standpoint of one interested in the oil industry, is the chapter devoted to "bituminous effusions." $f$ In this he describes the asphaltum deposit on the Hill

a House Doc. No. 129 (fide Antisell, 1857).

b Antisell, Thomas, Pacific R. R. Repts., vol. 7, 1857, p. 66.

$c$ Senate Doc. No. 14, Sacramento, 1855, 95 pp. (fide Antisell).

d Pacific R. R. Repts., vol. 7, pt. 2, 1857, pp. 65-74.

e Op. cit., p. 66.

fOp. cit., pp. 107-114. 
ranch, 6 miles west of Santa Barbara, and the deposit near Rincon Creek, east of Carpinteria. He failed to record the occurrence of the bituminous sands where Summerland now is, or of the deposits at Carpinteria.

1865. Whitney, J. D., Geology of the Coast Ranges from Buenaventura to Gaviota Pass. ${ }^{a}$ By far the best description of the geology of the region about Santa Barbara found in any of the older publications is that by Whitney, the second and last State geologist. Those portions of his narrative which pertain to areas not visited by the writer will be given in detail. The descriptions are given in the order in which the localities were visited by his party, which journeyed westward from Ventura to Gaviota and thence northward across the Santa Ynez Mountains.

From Ventura to Carpinteria the strip of land along the southern face of the mountains and between the mountains and the shore appears to be made up entirely of bituminous shales. ${ }^{b}$

High bluffs or steep hills skirt the coast, showing everywhere inclined strata, dipping from $25^{\circ}$ to $30^{\circ}$ to the southwest, with a few feet of horizontal beds of detrital material on the top. The slates [shales] are interstratified with fine-grained sandstones, and the formation is undergoing rapid denudation from the action of the resistless surf of the Pacific. The worn edges of the strata, planed off and polished by the waves, may be seen for some distance out from the shore at low water. The strike of these rocks is here from $\mathrm{N} .45^{\circ}$ to $55^{\circ} \mathrm{W}$. No eruptive rock was seen here, and only a few granite bowlders were observed on the beach; but immense numbers of sandstone pebbles were seen, some of which were quite fossiliferous.

About 5 miles southeast of Carpinteria the rock presents exactly the appearance of having had the bituminous matter burned out of it; it assumes various colors, such as bright red, rose, brown, yellow, and cream color, and it appears to have been partially fused in some places. These colors are made very conspicuous by the washing and smoothing of the rocks by the ocean.

The slates [shales] are black and highly bituminous where the outcrop strikes the sea, 3 miles to the southeast of Carpinteria, and large quantities of tarry asphaltum flow from them. For a mile or more along the shore the banks abound in it, and it saturates the beach sand and flows down into the sea.

The bituminous shales and asphaltum deposits in the vicinity of . Carpinteria are then described, together with a note on the "oil works" at that place: ${ }^{c}$

An establishment for distilling oil from the asphaltum was started shortly before the time our party visited the place (March, 1861), but access to it was not allowed nor information given. It is believed, however, to have been a failure, both as regards the quality of the oil produced and the profits of obtaining it.

These bituminous slates [shales] extend along the base of the Santa Ynez Range to the west and were explored by our party as far as the Gaviota Pass, about 45 miles from Carpinteria; they continue beyond this, but, it is said, not as far as Point Conception. The general dip along this line is to the south; but the strata are exceedingly contorted, being bent and twisted into every possible variety of curve. They 
are also metamorphosed and hardened, and the variations of hardness and color, as well as the elaborate curvings of the beds, are beautifully displayed in the broad, level surface worn off by the sea, and left visible at low tide. These contortions seem to be limited to a rather narrow belt near the shore. As we recede inland they becomre less conspicuous, and the strata regain gradually their regular southern inclination.

Here follows a general description of the extent of the Santa Ynez Range and its salient geologic features, together with a description of the hot springs northeast of Santa Barbara. Three geologic sections elucidate Whitney's conception of the geology of the range-one extending across it from the coast to a point north of Carpinteria, another from the coast to Santa Ynez River through Hot Sulphur Springs, and a third from a point on the coast west of Santa Barbara, through the Mission, and thence up toward the top of the range. Continuing the description of the range, Whitney says: "Metamorphic rock and conglomerate were seen on that [north] side, as also serpentine at the north base of the ridge." $a$

Whitney's description of the region west of Santa Barbara ${ }^{b}$ is given in its entirety, as it contains matter of much historic interest; furthermore, the writer has been over but a small portion of this country.

Wherever the [Santa Ynez] chain was examined to the west of the section last given [northeast-southwest through the Mission], as far as a point a few miles to the west of Gaviota Pass, the rock had always a dip to the south, at a high angle, the crest consisting of the broken edges of the sandstone, the bituminous slate [shale] resting on its flanks in the foothills, and both formations appearing entirely conformable with each other.

The bituminous slate [shale] is admirably exposed all along the seashore for several miles to the west of Santa.Barbara. At a point 1 mile in that direction, where the shales were planed down to the level of the ocean and the stratification could be most beautifully seen, the strike was noticed to be $\mathrm{N} .79^{\circ} \mathrm{E}$. and the dip $60^{\circ}$ to the south. In some places the slate [shale] forms low cliffs by the edge of the ocean; in others it has been denuded, and it is now covered by a more recent deposit. The complication of the disturbances in these strata may be well seen $* * *$ along the base of the bluff. *** These disturbances seem particularly common in the immediate vicinity of Santa Barbara. In some localities the rock has evidently been on fire, and the bituminous matter having been burned out-the operation continuing for several years, as it is said-the slates [shales] are left of various shades of red, produced by the oxidation of the iron.

The asphaltum, or hardened bituminous matter; occurs in the greatest abundance on the shore at Hill's ranch, about 6 miles west of Santa Barbara, and lies along the beach for a distance of a mile, in large masses. The bituminous slate [shale] is here covered unconformably, as at Santa Barbara, by a heavy deposit of post-Pliocene age, which here attains a thickness of from 80 to 100 feet. * * *

The bituminous slates [shales], which are highly contorted and turned up on edge, lie nearly on a level with the ocean. On their edges rests a body of soft arenaceous and loose gravelly materials, sometimes very slightly consolidated, in which are long fissures filled with asphaltum; this in some cases has risen to the surface of the formation and become accumulated, in large masses, in the overlying recent or alluvial formation. The gradual erosion of the cliff has exposed large masses of the asphaltum which have fallen down and accumulated in considerable quantity on the beach. 
* * * This locality has, for a long time, furnished all the asphaltum used for roofs and pavements in San Francisco, as it lies most convenient to the sea. In 1861 this material was sold in the city for $\$ 15$ per ton, the chief expense of obtaining it being that arising from the difficulty of getting it on board the vessel, on a coast exposed to the Pacific swell. It will be noticed that the asphaltum lies in the arenaceous rock or sandstone, over the bituminous shales, from which it was derived, and from which it has been forced out probably by heat and pressure. Through the slates [shales] them. selves the bituminous material appears to be uniformly diffused, and not concen. trated into pure masses. The asphaltum, as it lies on the shore, is necessarily much mixed with sand; specimens selected as of fair quality contained about 60 per cent of that material. No appearances of any soft, liquid, or tarry matter were noticed at this locality.

Extending westward from Hill's ranch, the bituminous slate [shale] occupies a strip from 1 to 3 miles wide, between the rugged Santa Ynez Range and the sea. It forms rounded hills, very green and grassy, the soil being fertile and retentive of moisture. The junction of the slates [shales] and sandstones could be accurately traced on the surface by the character of the soil and vegetation, as well as by the form of the hills. In ascending from the sea toward the interior, the chaparral, indicating a dry soil, is first met with on striking the sandstone. The ocean fogs help to supply this region with moisture, and few ranches in California can equal in beauty and fertility those situated on the bituminous slates [shales] along this part of the coast. Of these, the ranches of Mr. Hill and Doctor Denn (Dos Pueblos) and the Rancho El Capitan are the most noted. At the Tortegas ranch the belt of slate [shale] is narrower, appearing to be about $1 \frac{1}{2}$ miles wide, which width it holds as far as we traced it, to beyond the Gaviota Pass. Throughout the whole of this extent it has a strike nearly parallel with that of the chain, and everywhere a southern dip, conformable to that of the sandstone which underlies it. At one locality, a short distance west of camp 20, in the cliffs at the base of the ranch called El Capitan, the sea has made a section very nearly at right angles to the strike, and the dip is seen to be quite uniform, being everywhere from $30^{\circ}$ to $40^{\circ}$. A portion without apparent break or fault was measured along the bluff on the beach, which represented a perpendicular thickness of about 1,300 feet of slate [shale]. The actual thickness is, however, much greater, probably more than twice as great; but, owing to breaks and faults, this is the greatest thickness measured in any one place, where the rocks were unquestionably not folded, and where the whole could be minutely examined. This portion of the slate [shale] seemed less bituminous than that at Santa Barbara, but still it was, in places, highly charged with this substance.

The last paragraph relating to the environs of Santa Barbara describes the fossiliferous Pliocene and post-Pliocene deposits found along the coast.

1882. Peckham, S. F., Examination of the bituminous substances occurring in southern California. ${ }^{a}$ No other of the earlier writers has taken a more optimistic view of the oil industry of California or has more clearly foreseen its possibilities or more intelligently described the surface occurrence of the bituminous products than Professor Peckham. Here are his opening paragraphs in the paper referred to above, written in June, 1866:

To speak seriously of the "oil interests of southern California" draws forth from the majority of the citizens of this State a smile of incredulity or ridicule. To urge theit claims to consideration as a field for profitable investment presents to most men strung

a Geol. Survey California, Geology, vol. 2, Cambridge, Mass., 1882, appendix F, pp. 40-90. 
reasons for doubting your sanity. Yet the southern portion of this State has veritable oil interests, which only need the fostering care of men of sound judgment, aided by sufficient means, to enable this section to ultimately furnish this entire Pacific coast with both illuminating and lubricating oils, at prices that will render futile all competition of eastern products.

Such are the facts as they exist to-day; but, at the same time, with the great mass of this community, and, it may be said, with that of the entire country, so far as it has at any time received attention, this interest was never more depressed in commercial value than at present. The only reason that can be assigned for such an anomalous condition is the fact that real merit has been obscured and rendered contemptible by excessive falsehood and exaggeration, and that a natural production, capable of profitable development, has been made an object of distrust and suspicion by false definitions and spurious representation.

I Farther on in this paper ${ }^{a}$ the asphalt deposits and bituminous formation exposed east of Point Conception and in the neighborhood of Bigg's ranch, at Rincon Point, are briefly described, and under the heading of "Chemical investigations," the chemical properties of the oil and asphalt of Santa Barbara, Ventura, and Los Angeles counties are carefully described.

I 1884. Hanks, Henry G., The minerals of California. ${ }^{c}$ Mention is made of the Carpinteria asphalt deposits on page 287 of this report.

1887. Finch, W. W., Infusorial earth at Santa Barbara, Cal. ${ }^{d}$ This short paper consists of brief descriptions of the diatomaceous deposits north of Santa Barbara, together with some general information concerning diatoms.

, 1888. Goodyear, W. A., and Weber, A. H., Petroleum, asphaltum, and natural gas in Santa Barbara County.e This report sums up the development work done in the county, which includes wells put down at Summerland by H. L. Williams on Ortega Hill, another well put down ten years previous on the flat at the foot of the hill, two wells sunk by the "Santa Barbara Oil Company" in Oil Canyon in 1885 , and a well sunk 3 or 4 miles north of Carpinteria. In addition there are brief descriptions of the asphaltum deposits at Carpinteria and east of Goleta (Hill's ranch).

1890. Ford, H. C., Solfataras in the vicinity of Santa Barbara. ${ }^{f}$ As this paper contains considerable data having not only a local but a general bearing on the subject of the burning of the bituminous shales, and is published in a bulletin inaccessible to most people interested in the subject, it has been deemed advisable to reproduce a considerable portion of it here:

The second group of "fire wells" visited are about three-fourths of a mile below a point where the Rincon Creek enters the sea and near the carriage road and railway

a Op. cit., pp. 50-51.

$b$ Op. cit., pp. $73-90$.

c Fourth Ann. Rept. California State Mineralogist, 1884, pp. 67-397.

a Bull. Santa Barbara Soc. Nat. Hist. No. 1, 1887, pp. 8-11.

e Seventh Ann. Rept. California State Mineralogist, 1888, pp. 89-91.

f. Bull. Santa Barbara Soc. Nat. Hist., vol. 1, No. 2, October, 1890, pp. 53-56. 
leading from Santa Barbara to Ventura. Before the grading of the railway was accomplished, the traveler by the beach road might have noticed some peculiar-looking rocks that had fallen from the cliffs above. The rocks appear to have been originally similar to those composing the mass of the exposed portion of the cliff, which are principally light-colored shales, but their character, both in density, specific gravity, and color, has been altered by the action of mineral gases and great heat. Nearly all shades of red, yellow, and brown, and in some cases green, are colors represented. The intensity of the heat at some former period seems to have contracted the strata through semifusion until it is excessively hard and gives a metallic ring when struck with a hammer.

Reaching by an easy path a point about 300 feet above the base of the cliff, I was at once aware of the near existence of the "solfatara," or so-called "Rincon volcano," by the same exceedingly disagreeable odors that were noted in the Santa Ynez issue.

Descending 20 or 30 feet, I found hót gases bursting from numerous apertures in the shales, accompanied in some cases by melted bitumen that hardened in concretionary masses upon coeling. The dip of the strata was at an angle of $50^{\circ}$ toward the mountain. Crystals of sulphur had also formed upon all objects near the issue, and naphtha appeared to be present. A few years ago a tunnel was run into the cliff at its base to the depth of 200 feet in search of oil. At this depth the workmen were obliged to cease operations in their endeavor to penetrate farther on account of the -great heat. Upon entering this tunnel I found the temperature still high, but noticed only weak sulphurous gases. Near the entrance for 50 or 60 feet the roof and sides were thickly covered with attenuated colorless crystals of epsomite hanging in tufts and masses.

During the cooler months, as at the Santa Ynez locality, the gases arising from the principal orifices are seen from distant points, and the issue of so much smoke and accompanying heat has given rise to a popular idea that it is due to volcanic action. The local journals have from time to time given voice to this idea, and the frequency of earthquake shocks in the neighborhood has been attributed to the struggling efforts of the "Rincon volcano." When the excavations of the Southern Pacific Railway were made at a point a mile farther west from the locality just described, a similar issue was discovered, and upon touching a match to the gas combustion ensued and continued, notwithstanding vigorous efforts were made to extinguish it. The fumes caused much annoyance to the laborers, and not until masses of earth were dumped over the orifice did it cease to burn.

During the summer of $1888 \mathrm{Mr}$. Richardson, who resides a short distance below the Rincon "fire wells," was startled by loud reports in their direction, and upon visiting the locality observed flames issuing to the height of several feet from the apertures. Parties from Santa Barbara visited the spot upon hearing of this outburst and confirmed Mr. Richardson's observations.

Apparently there have been periods of great activity, followed by long intervals of comparative rest. The partially fused rocks, with their altered color and density, would indicate a period of greater intensity of heat than at present prevails.

1894. Fairbanks, H. W., Geology of northern Ventura, Sants Barbara, San Luis Obispo, Monterey, and San Benito counties. This description of the general geologic features of the southern Coast Ranges is the most comprehensive one yet published. The statement is made on page 501 that the main portion of the Sants Ynez Range is Miocene. This is certainly not true for those portions examined by the writer, as in the region north of Summerland and 
Santa Barba:a the range is largely Eocene (Topatopa). The asphaltum and petroleum deposits of Santa Barbara and vicinity are mentioned on pages 31 and 357 , respectively, of the same report. On the latter page is a description of the Occidental wells and the Santa Monica Oil Company's wells north of Summerland.

1897. Watts, W. L., Oil and gas yielding formations of Los Angeles, Ventura, and Santa Barba:a counties. ${ }^{a}$ In part 3 of this report, devoted to the region between Santa Paula, Ventura County, and Summerland, Santa Barbara County, Watts describes the Punta Gorda asphalt mine east of Rincon Creek; the Las Conchas mine and asphaltum works and the Higgins well at Carpinteria; the Fischer oil wells at Loon Point, near Ortega station; the Occidental oil wells, 5 miles northeast of Summerland; the Santa Monica Oil Company's wells, 2 miles north of Carpinteria, and the oil wclls at Summerland belonging to H. L. Williams; Darling \& Turner; Alameda and Santa Barbara Development Company; Bachus \& Cravens; Cole; Dewlaney; Doulton \& Wilson; Forester \& Treadwell; Loomis; Moore; Stevens \& Roberts; and Darling Brothers; also the Cone gas wells. In addition to the above there is a brief description and résumé of the geologic formations and a geologic sketch map of the field.

1900. Watts, W. L., Oil and gas yielding formations of California. ${ }^{b}$ In chapter 1 of part 6 , which is devoted to the Summerland oil field and productive wells in Santa Barbara County, Watts describcs the development which had taken place since the time of his previous visit in 1895, together with some general observations concerning the geology of the wells, value of the oil, etc., and includes a list of the oil producers and wharf owners at Summerland. Under the heading "Prospect wells in Santa Barbara County" the following wells, found within the Summerland district, are mentioned: A ctic Oil Company's wells Nos. 1 and 2, 7 miles south of Rincon C-cek,

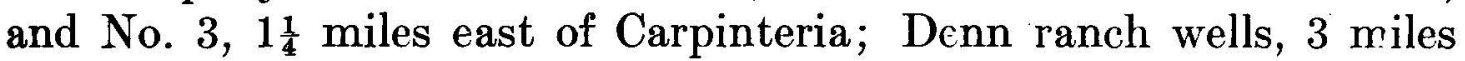
west of Goleta; J. Heath's well, near mouth oî Rincon Crcek; Illinois Oil and Asphalt Company's well at Montecito; Robinson well, near Serena; Santa Barbara and Naples Oil and Development Company's well, 15 miles west oî Santa Barbara; Stevens, Clark \& Duncan well, at Loon Point; and the Treadwell well, between Loon Point and Serena. Some distillation tests of the Summerland oil are given on page 203 of the report. (See table on page 63 of this bulletin.)

1901. Eldridge, George H., The asphalt and bituminous rock deposits of the United States. ${ }^{c}$ The general geologic features and the asphalt deposits of the region from Gaviota to Punta Gorda are

a Bull. California State Mining Bureau No. 11, 1897, 94 pp., 35 figs.

$b$ Ibid., No. 19, 1900, 236 pp., 35 figs., 13 maps.

c Twenty-second Ann. Rept. U. S. Geol. Survey, pt. 1, 1901, pp. 209-452, pls. 25-53, figs. 1-52,

1783-Bull. 321-07-2 
described by Eldridge in this report, pages 439 to 446 . The deposits in the vicinity of Gaviota, Mores Landing (La Patera mine), Carpinteria (Las Conchas quarry), and Punta Gorda are treated in detail, the text being supplemented by many fine illustrations.

1902. Arnold, Delos and Ralph, The marine Pliocene and Pleistocenc stratigraphy of the coast of southern California. ${ }^{a}$ In this paper the Packards Hill and Bath-house Beach beds are briefly described and correlated with similar beds at other points along the coast.

1903. Eldridge, George H., Petroleum fields of California. ${ }^{b}$ A section of this summary report (pages $313-315$ ) is devoted to a description of the Summerland field. The conclusions reached by the writer agree in the main with those expressed by Eldridge in this report.

1903. Arnold, Ralph, The paleontology and stratigraphy of the marine Pliocene and Pleistocene of San Pedro, Cal. ${ }^{c}$ On pages 50 to 54 of this paper the writer describes the Pliocene and Pleistocene deposits in the vicinity of Santa Barbara in more or less detail, supplementing the notes on the geology by lists of the species of fossils. (See p. 32.)

1904. Prutzman, Paul W., Production and use of petroleum in Cali:ornia.d In this valuable paper Prutzman devotes a brief section to a description of the Summerland field, together with a statistical table of the number of producing wells, etc., in December, 1903. References to the refinery at Summerland and to the physical and chemical properties and uses of the oil found there are included in the body of the report.

\section{HISTORICAL OUTLINE.e}

The first oil well in the Summerland field of which we have any record was sunk on the flat one-fourth mile east of Ortega Hill about $1877 .^{f}$ This well is said to have penetrated to a depth of about 180 feet and to have encountered quicksand with oil. It was never operated. About ten years later (1887) H. L. Williams sunk two wells, one 455 feet deep, on Ortega Hill. These penetrated two oil sands. In 1891 Darling Brothers drilled a well about 1,200 feet northwest of the Summerland station and obtained a flow of gas under an 8-pound pressure sufficient to supply 17 families with fuel. A year later the same men sunk another well in the same vicinity and obtained similar results. Sometime previous to 1895 two gas wells, known as the Cone wells, were sunk in the northwestern part of Summerland. Between 1891 and 1895 there was considerable activity in the field,

a Joui Geol., vol. 10., No. 2, 1902, pp. 134-135.

$b$ In Contributions to Economic Geology for 1902: Bull. U. S. Geol. Survey No. 213, 1903, pp. 306321.

c Mem. California Acad. Sci., vol. 3, 1903, 420 pp., 37 pls.

d Bull. California State Mining Bureau No. 32, 1904, 230 pp., 29 tables, 64 half-tones, 54 figs.

e Most of the historical data here recorded have been gleaned from Watts's two reports on this fidl in Bulletins Nos. 11 and 19 of the California State Mining Burequ. (See p. 15.)

$f$ Seventh Ann. Rept. California State Mining Bureau, 1888, p. 90. 
and by the end of the latter year there were 28 productive wells, which produced 16,904 barrels of oil in 1895. Up to this time the development was confined mostly to the terrace on which the town of Summerland is located, although Mr. Williams had three wells on the beach at the west end of the town.

Stimulated by the success of the wells previously drilled, and doubtless guided somewhat by the suggestions offered by Watts in Bulletin No. 11, the development in 1896 began along the beach and finally extended out toward the ocean, the wells being drilled from wharves built out over the water.

In June, $1900^{\circ}$, there were at Summerland 305 producing wells, 59 abandoned wells, and 15 well sites at which drilling operations had been commenced. These wells yield from 1 to 60 barrels of oil a day, the average yield being 5 barrels a day. The value of the oil in 1899 was 90 cents a barrel f. o. b. at Summerland. The cost of production is said to range from 25 to 35 cents a barrel. $a$

There were 22 companies operating and 12 wharves in use in 1899.

Development continued up to about 1901 or 1902 , at which time there were still about 20 companies in the field. Since 1902, owing to certain adverse conditions of price and marketing, the field has been declining. At the end of $1903^{b}$ there were 198 producing wells, 114 not producing, and 100 abandoned. The approximate price per barrel at that time was 80 cents. At the present time (October, 1906) there are 189 producing wells out of the 412 which at one time or another have been drilled in this field. The companies still operating, 14 in number, are listed on page 67.

\section{LOCATION.}

The Summerland oil district is situated in Santa Barbara County, on the coast of California, between 80 and 90 miles west-northwest of Los Angeles and about 350 miles southeast of San Francisco. (See fig. 1.) The region mapped comprises an area of about 52 square miles, in the shape of a rectangle 13 miles in extent east and west along the shore by about 4 miles in width north and south. It includes at its west end the city of Santa Barbara (population 6,587 in ;1900), one of the oldest settlements in California, which lies at $34^{\circ} 25^{\prime}$ north latitude and $119^{\circ} 42^{\prime}$ west longitude. The district is reached by the Coast division of the Southern Pacific Railroad, which here follows the coast, and by vessels which touch at the port of Santa Barbara. The town of Summerland, at which the only productive oil field so far developed in the district is situated, lies nearly 6 miles east of Santa Barbara. 


\section{TOPOGRAPHY.}

The Santa Ynez Mountains, which extend for over 60 miles from Ventura River to Point Conception, are the dominant topographic feature of the region. (See Pl. I.) These mountains are part of the east-west system of ranges which prevails in the region south of the upper end of the great interior valley of California, and

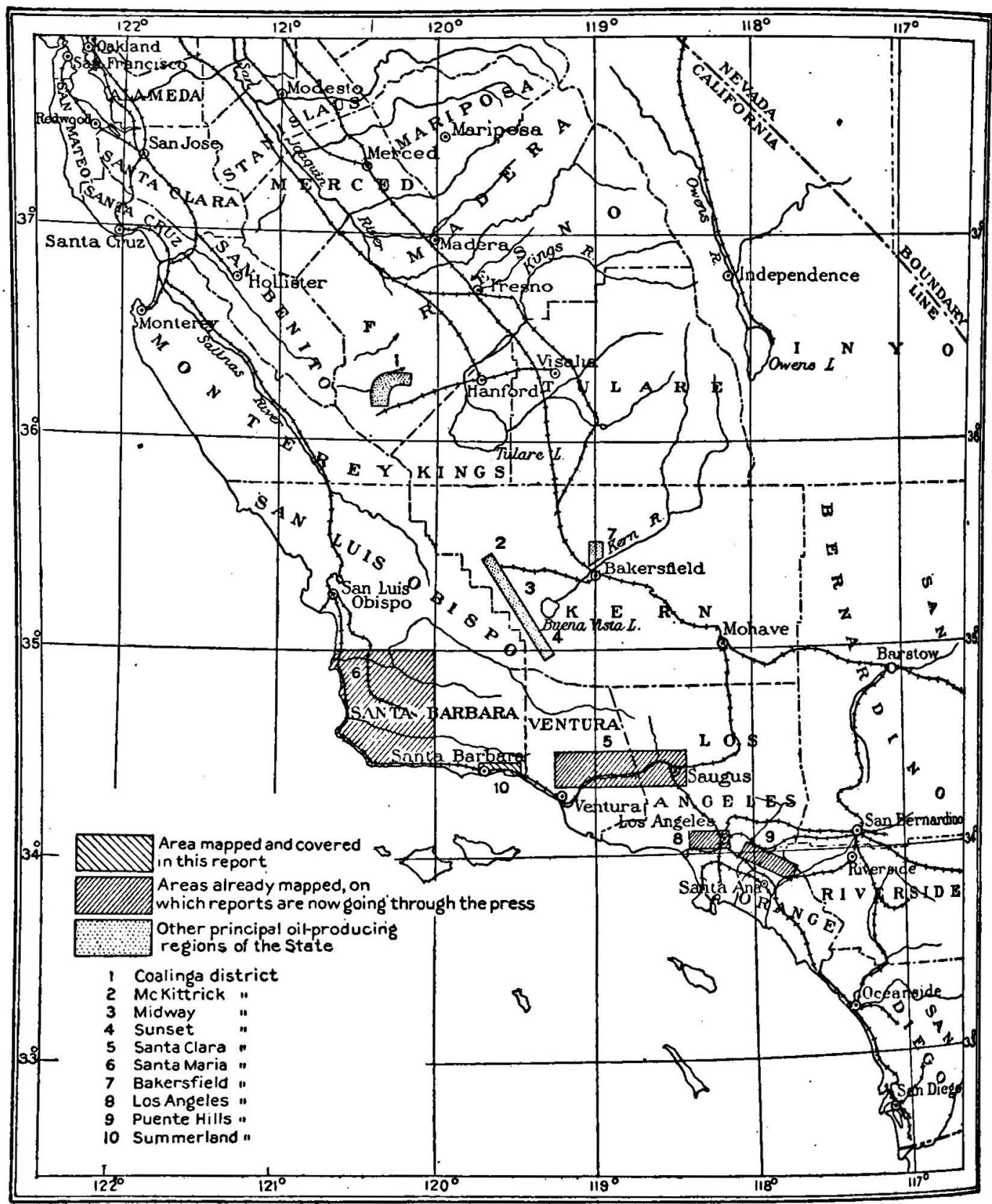

FIG. 1.-Index map of a portion of southern California, showing location of district described in this bulletin and of the other important producing districts of the State.

determines the trend of the coast along this part of the State. They terminate between Points Conception and Arguello, the two salients about which the coast bends abruptly from an east-west to north-south trend. The mapped area embraces the south flank of that portion of the range lying back of Summerland and Sants 





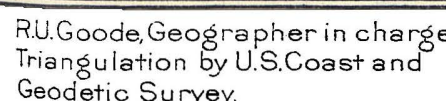
GEOLOGIC AND STRUCTURAL MAP OF THE SUMMERT SCAD OIL DISTRICT, SANTA BARBARA COUNTY, CALIFORNIA
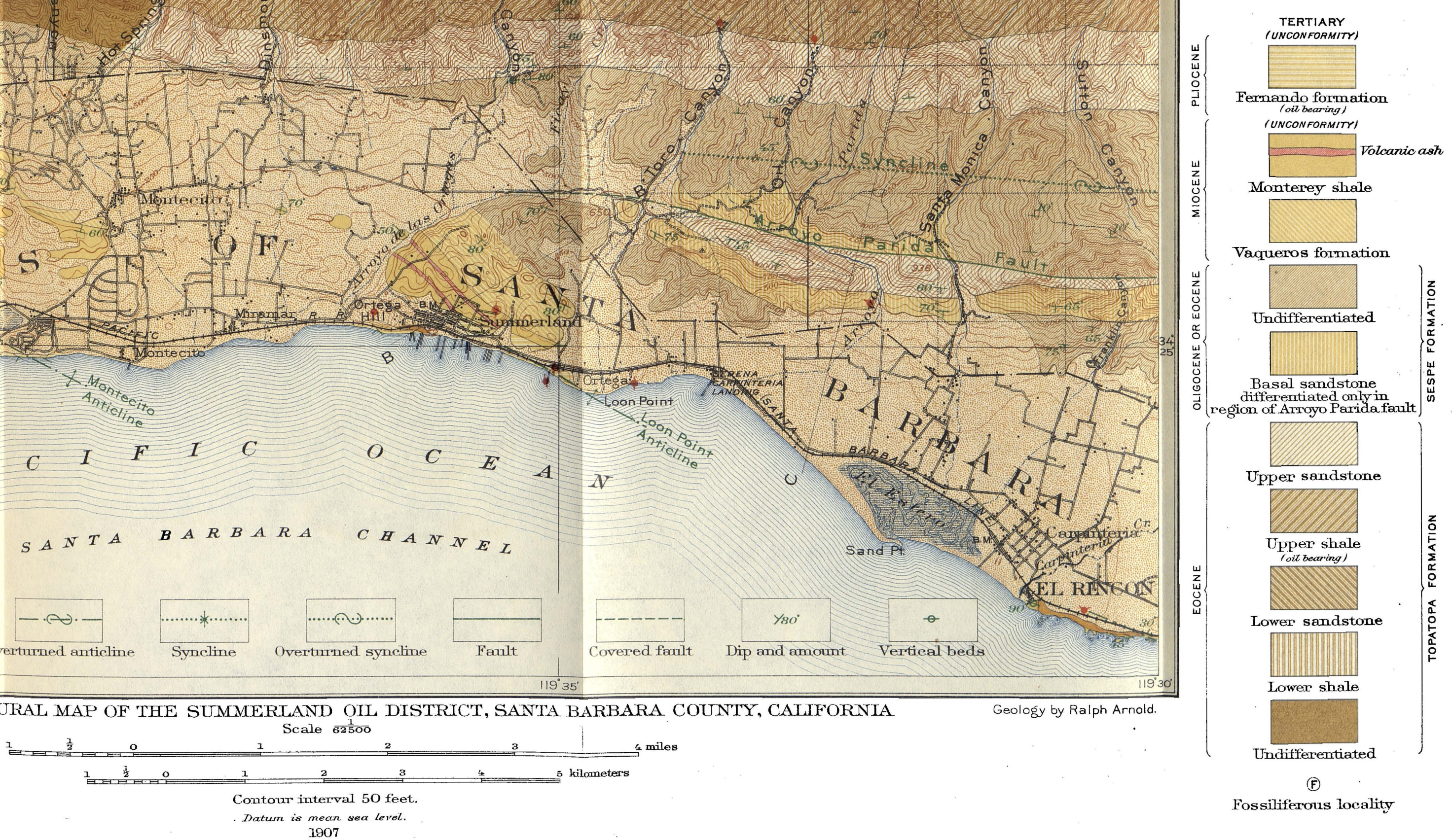

Barbara. The mountains present a bold, rugged front and a more or less serrate crest, the variation in altitude along the summit being from 3,300 to nearly 4,000 feet. La Cumbre Peak, elevation 3,985 feet, 5 miles north of Santa Barbara, is the highest point in the region.

Many canyons cut the range at right angles; these are steep and narrow and in many places toward their heads have precipitous sides. They usually drain cirque-like basins which lie close to the axis of the main ridge. Streams flow from the larger canyons and debouch over alluvial fans onto the sloping terrace which skirts the coast. In the summer these streams are comparatively small, but during the rainy season they sometimes assume torrential proportions and carry bowlders of enormous size out onto the lowlands for distances of over a mile. The vegetation of the mountains is confined largely to dense growths of chaparral and other brush, with sycamores and alders in the canyons. Live oaks are found over the lowlands in places, especially in the vicinity of Montecito.

Back of both Summerland and Santa Barbara, between the mountains and the sea, are long comparatively flat-topped hills which rise to elevations of 600 to 1,100 feet. These ridges, and the long, low knolls which lie in the Montecito Valley between them, are doubtless blocks which have been faulted up relative to the region on their north. Their north sides, coinciding with the fault zone, are steep, while their south slopes are more gentle.

Mission Ridge, back of Santa Barbara, and the eastward continuation of this ridge beyond Sycamore Canyon, show marked evidence of terracing. These terraces, which are of marine origin, have been subjected to differential uplift since their formation, as is indicated by their varying elevations at different points. The highest terrace, represented by the top of the ridge, is about 850 feet above sea level in its western portion, but immediately west of Sycamore Canyon it is only a little more than 750 feet; just south of the canyon the highest remnant of the same terrace lies at 666 feet, and this slopes off to a little more than 550 feet west of Montecito. This change in elevation of approximately 300 feet takes place in about $2 \frac{1}{2}$ miles. On. the south side of Mission Ridge there are remnants of old terraces at elevations of 600 feet at the west end and 650 feet at the east end. Traces of terraces can be seen, at elevations of 250 to 300 feet, south of Sycamore Canyon. There are also evidences of terraces in the hills back of Summerland and Serena, but none as marked as those on Mission Ridge.

The lowland along the coast represents an old terrace which is in large part of marine origin. The terrace, or possibly terraces, for there is no direct connection between some of the isolated flats, varies in elevation from sea level to over 150 feet-the latter being 
near the light-house 2 miles southwest of Santa Barbara. Ortega Hill and the little hill southwest of Ortega station (see Pl. II, $A$ ) are local elevations, due, at least in part, to differential elevation of the terrace along lines coincident with anticlinal axes. The surfaces of these old terraces, and also nearly the whole surface of the region adjacent to the base of the Santa Ynez Mountains, are covered by detrital deposits, more or less waterworn (see Pl. II, $B$ ). These are discussed under the heading "Pleistocene deposits" on pages 33-35.

Estuarine conditions are prevalent along the coast east of Santa Barbara and west of Carpinteria, and indicate local subsidence coincident in time with the elevation which has taken place over most of the coastal belt.

The valley in which the city of Santa Barbara is located is broad, and slopes gradually back from the ocean toward the north and west. The depression is due largely to structural causes, although erosion has played some part in the development of its minor features. The hills bounding this valley on the west are composed of soft Pliocene sediments which have been faulted into their present elevated position, the fault line probably being coincident with their northeastern base.

The local relief in the group of hills back of Summerland has been due in a measure to the composition of the exposed formations, and follows in a general way the strike of the rocks, which is here northwest and southeast. The terrace on which Summerland is situated is a quarter of a mile wide and from 30 to 60 feet in elevation, and slopes gently from the hills to its western boundary, a sea cliff. (See Pl. II, A.)

Drainage lines, such as San Roque Creek, Sycamore Canyon, and Toro Canyon, which cut directly through the outer hills, were in existence before the movements which produced the salient local topographic features took place. 


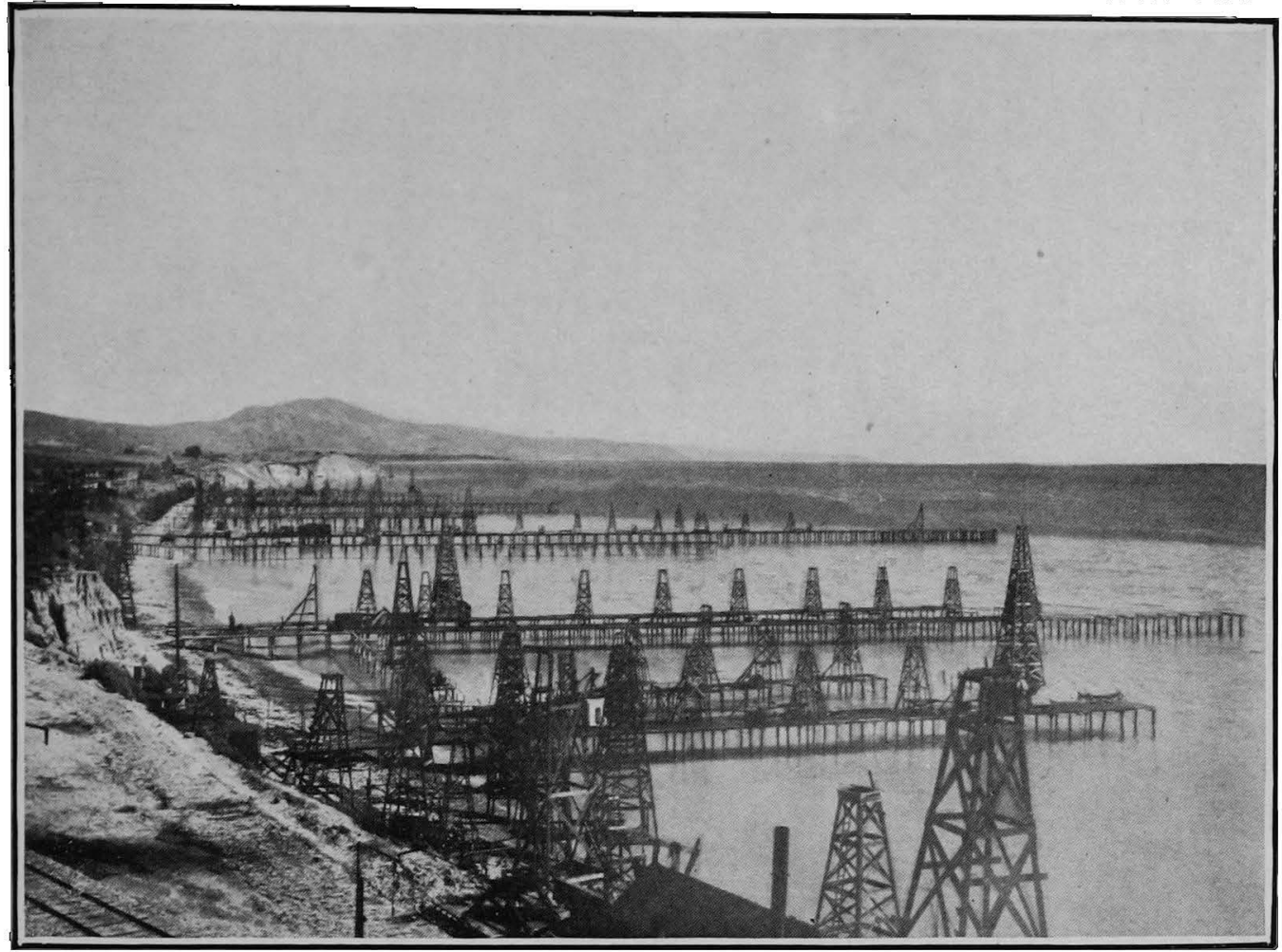

A. SUMMERLAND FIELD. FROM ORTEGA HILL, LOOKING SOUTH.

Showing general configuration of coast, terrace on which Summerland and some of the wells are situated, and location and relative lengths of the various wharves.

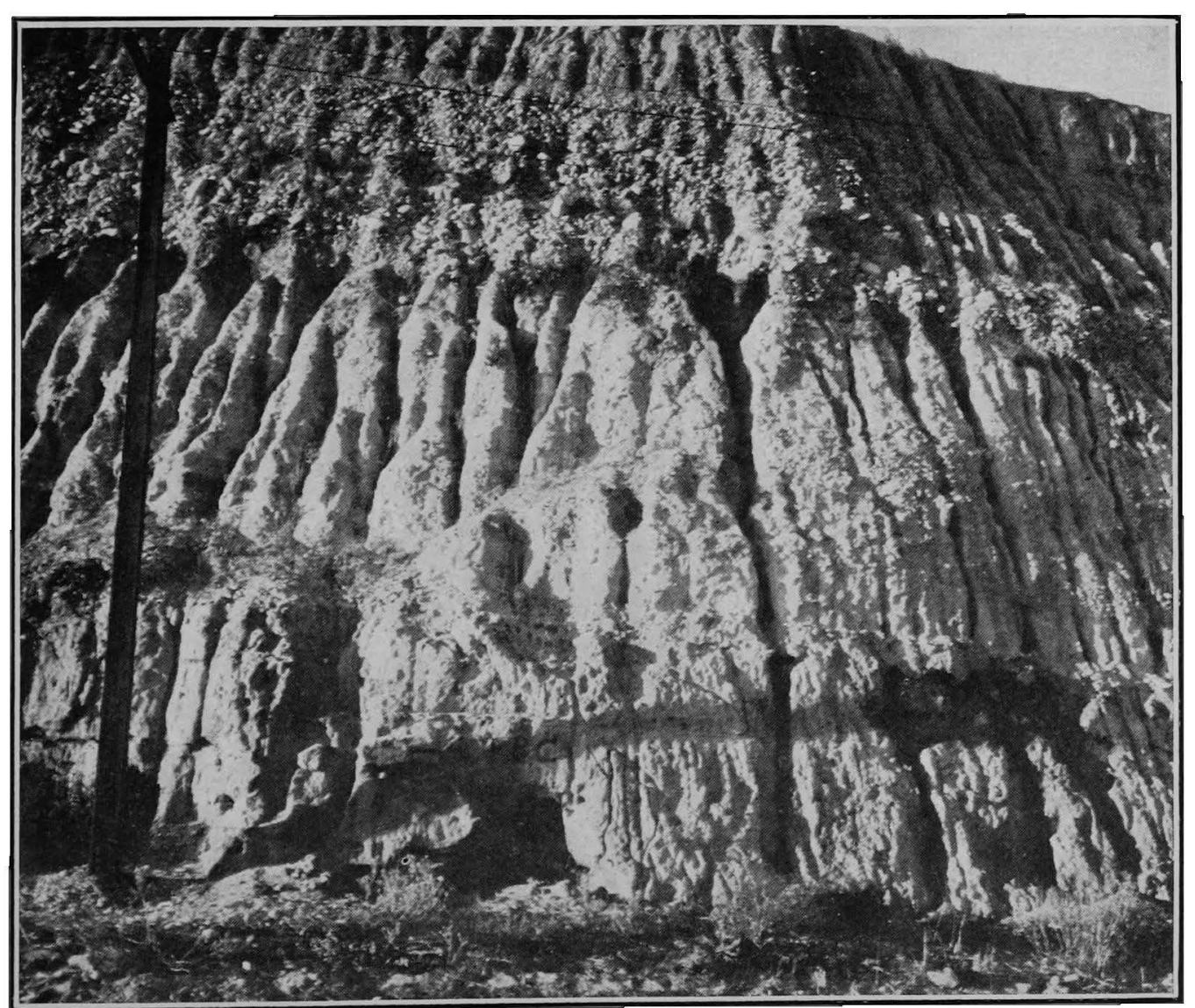

B. PLEISTOCENE BEDS IN RAILROAD CUT WESt OF SUMmERLAND. LOOKING NORTH. Dark sandstone at base is heavily charged with asphaltum derived from overturned oil-bearing Fernando beds below. 



\section{GEOLOGIC FORMATIONS.}

\section{GENERAL STATEMENT.}

The formations involved in the geology of the Summerland district are $9,000 \pm$ feet oi conglomerate, sandstone, and shale of the Topatopa (Eocene); 4,300 \pm feet of conglomerate, sandstone, and shale of the Sespe (Eocene or Oligocene) ; 2,400 \pm feet of sandstone and shale of the Vaqueros (lower Miocene); $1,900+$ feet of shale and volcanic ash of the Monterey (middle Miocene); $1,000+$ feet of conglomerate, sandstone, and clay shale of the Fernando (upper Miocene-Pliocene); and $50+$ feet of gravel, sand, and clay of the Pleistocene-in all, $18,650 \pm$. feet of sediments, practically all of Tertiary age. Unconformities occur between the Monterey and Fernando formations and between the latter and the Pleistocene. Reference to the geologic and structural map (PI. I, p. 18) will elucidate many of the points in the descriptions of the formations which follow.

Tentative correlation of formations of Summerland district with the standard Calfornia Coast Range and Santa Clara Valley sections. .

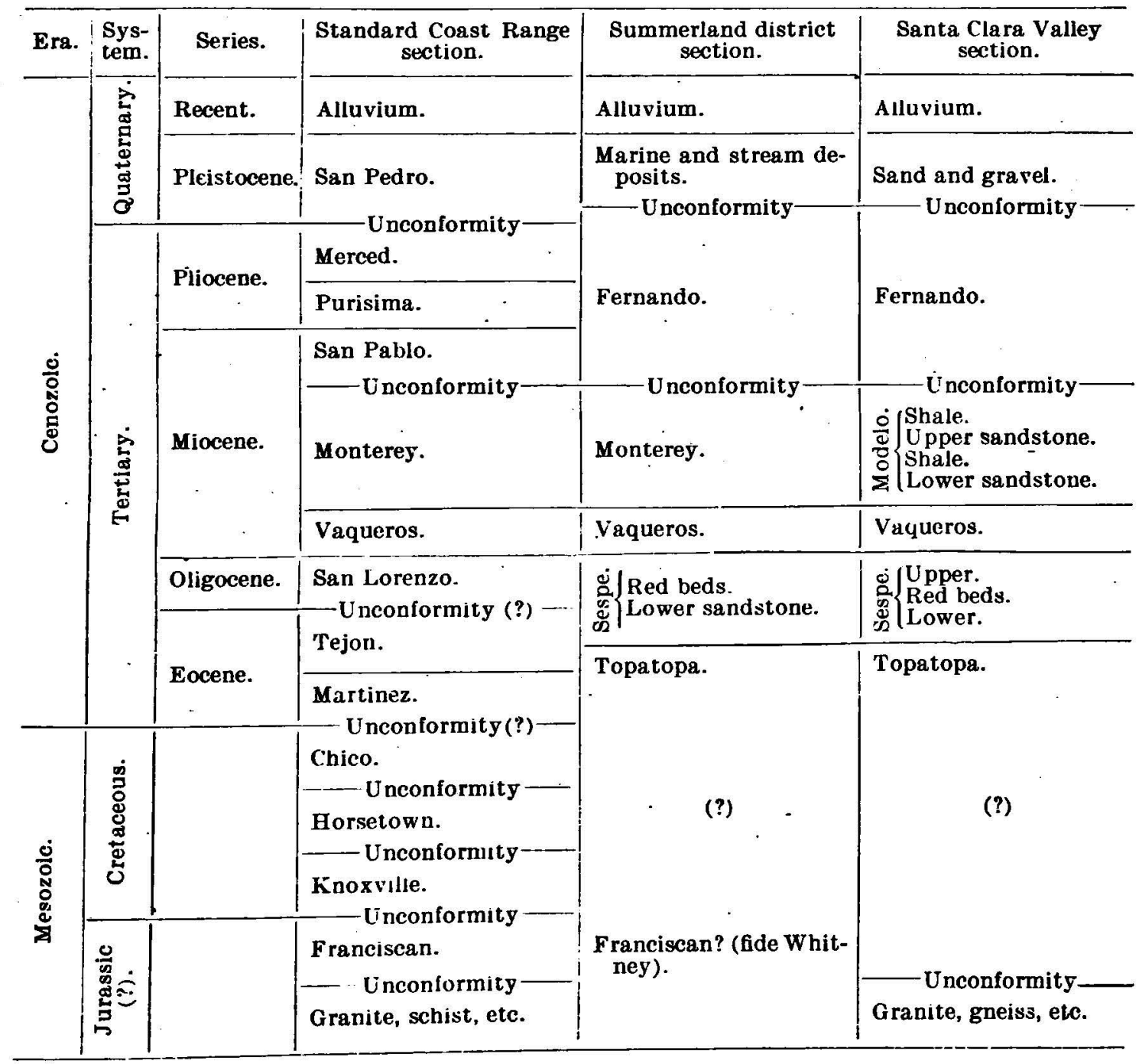


TOPATOPA FORMATION.

Name.-The name Topatopa was given by Eldridge ${ }^{a}$ to a formation of conglomerate, sandstone, quartzite, and shale exposed in the Topatopa Range north of the Santa Clara Valley, Ventura County, about 30 miles east of the Summerland district. As the deposits thus described are directly traceable into a similar series occurring in the Santa Ynez Range in this district, Eldridge's name has been employed to designate the latter formation.

Iithologic character.-Four zones, the upper three each approximately 2,500 feet in thickness, the lowest at least 1,200 feet thick, are recognizable in the Topatopa formation north of Summerland. The lowest zone is predominatingly dark-drab to greenish shale, generally thin bedded, with varying amounts of yellowish, grayish, and drab interbedded sandstone. The sandstone layers range in thickness from a fraction of an inch to several feet and in grain from fine to pebbly. The sand grains are largely quartzitic and the pebbles granitic, as they are also throughout the remainder of this and the succeeding (Sespe) formation. The shale contains some carbonaceous material, scattered fish integuments, and what are supposed to be ostracods.

The second zone is similar to the first except that in the second the sandstones are relatively much more important than the shales, some of the sandstone beds approaching 25 or 50 feet in thickness.

Above this sandstone zone is a very prominent band of dark-gray to greenish thin-bedded shale, which, owing to its soft composition, forms a swale in all the ridges running down from the crest of the range for many miles along its front. Some decidedly calcareous beds are associated with the shale, as are also some thin beds of sandy material. Many tar springs occur in the shale about the region of Toro and Oil canyons, and in it the wells of the Occidental Oil Company, in the latter canyon, described on page 55, were drilled.

The uppermost zone of the Topatopa consists largely of hard sandstone and conglomerate, with here and there more or less prominent belts of gray shale, and is sparingly fossiliferous throughout. The sandstone beds vary in thickness from a few inches to 50 or 60 feet, the thicker beds appearing near the stratigraphic top of the series, toward the foot of the steep slopes. A row of prominent knobs on the transverse ridges of the south face of the range (immediately in front of the swales described as being weathered out of the shale) are determined by the position of the hard sandstone beds at the base of this uppermost member of the Topatopa.

Some very good building stone is obtained from the Topatopa formation near the base of the mountains and also from bowlders of the same rock found on the detrital slopes south of them. 
Age and fossils.-The age of the Topatopa formation is Eocene, as shown by characteristic fossils found in it both in the type locality and in the region of Santa Barbara. Many fossiliferous layers occur throughout the upper sandstone member of the formation, but most of these contain only poorly preserved oysters. However, at one locality on the La Cumbre trail, on the ridge between Rattlesnake and Sycamore canyons, north of Santa Barbara, the writer collected the following fauna from the sandstone about 1,000 feet stratigraphically below the top of the Topatopa formation:

Eocene fossils from the Topatopa formation on the ridge between Rattlesnake and Sycamore canyons, Santa Barbara, Cal.

Cardium brewerii Gabb (Young) (Pl. IX, Meretrix sp. indet.

fig.' 5).

Galerus excentricus Gabb (Pl. X, figs. 3a and $3 b$ ).

Leda gabbi Conrad (Pl. X, fig. 1).

Mactra near ashburneri Gabb (Pl. X, fig. 6).

Meretrix uvasana Conrad (P1. IX, fig. 1; Pl. X, fig. 5).

Modiolus ornatus Gabb (Pl. X, fig. 4).

Ostrea idriaensis Gabb (Pl. IX, fig. 2).

Phacoides cretacea Gabb (Pl. IX, fig. 4).

Phacoides sp. (small, gibbous).

Spirocrypta pileum Gabb (Pl. X, figs. 8, $9 \mathrm{a}$, and $9 \mathrm{~b})$.

Thracia (?) sp.

Turritella uvasana Conrad (Pl. X, fig. 7).

Distribution and structure.-The Topatopa formation occupies the whole front of the Santa Ynez Mountains from the region of the Ojai Valley at least as far west as Santa Barbara. In the region north of the Ojai Valley it forms the heart of a great anticline overturned toward the south; farther west, in the region of Chismahoo Mountain, the same anticline is normal; but still farther west, in the region back of Summerland and Carpinteria, the anticline is again overturned toward the south and the beds, from the foot to the summit of the range, all dip northward at angles varying from $40^{\circ}$ to $90^{\circ}$, the youngest apparently being at the bottom of the series. Northeast of Summerland and north of Carpinteria a long, narrow block of uppermost Topatopa sandstone and shale, dipping steeply to the south, is thrown up on the south side of a prominent east-west fault.

Evidences of petroleum.-The Topatopa is petroliferous in the type locality in the Sespe region, and, as previously mentioned, tar springs are found in the upper shale member of the formation in Oil and Toro canyons. Furthermore, wells put down in the vicinity of these lastmentioned springs have yielded some $14^{\circ}$ to $17^{\circ}$ oil. Besides these occurrences, oil seepages are said to occur in the Topatopa brown sandstones and shales in the canyon of Arroyo Parida, northeast of Serena, and at several other localities in the same formation along the south face of the Santa Ynez Range. Taken as a whole, however, the structure of the formation in the Summerland district offers only moderate inducements for prospecting with the drill.

Water from the Topatopa formation.-Hot springs emanate from the rocks of the Topatopa formation in Hot Spring Canyon, 4 miles 
northeast of Santa Barbara. According to Whitney, ${ }^{a}$ the waters from these springs are highly charged with sulphur, and had in March, 1861 , temperatures ranging from $112^{\circ}$ to $118^{\circ} \mathrm{F}$., the larger ones being usually the warmer.

The following is an analysis ${ }^{b}$ of water from the tunnel or one of the wells of the Occidental Oil Company in Toro Canyon, which are sunk in the upper Topatopa shale zone:

Analysis of water from Occidental wells, Toro Canyon, 3 miles northeast of Summerland.c

309.578

This water passed directly into a boiler without going through the heater would scale and cause some pitting, but in the heater the lime and magnesium are largely precipitated.

\section{SESPE FORMATION.}

Name.-The name "Sespe brownstone formation" was first used by Watts ${ }^{d}$ in describing the peculiar reddish-brown sandstone series found in the region of the Sespe Canyon, north of Fillmore, Ventura County. Later the name was used by Eldridge ${ }^{e}$ for the charactersstic reddish formation of which the Sespe brownstone is a part. The name is used in this report to designate the reddish formation which occurs along the flanks of the Santa Ynez Range north of Santa Barbara and Summerland, and which is directly traceable into Eldridge's areas in Ventura County.

Lithologic character.-Two general divisions are recognizable in the Sespe formation - a sandy basal portion about 1,900 feet thick and a shaly upper portion about 2,400 feet thick. The middle of the formation is of a decidedly characteristic reddish color, but this fades out gradually both toward the bottom and toward the top. The lowest zone in the Sespe is about 300 feet of heavy-bedded coarse

$a$ Geol. Survey California, Geology, vol. 1, 1865, p. 128.

- This analysis was found in Mr. Eldridge's notebook, accompanied by the following note: "Given me by Mr. Rust, of the Seaside Oil Company. Analy sis by Dearborn Drug and Chemical Company, Chicago, September 6, 1900."

c Expressed by analyst in grains per gallon; recomputed to parts per million at United State Geological Survey.

$d$ Bull. California State Mining Bureau No. 11, 1897, p. 25.

a Bull. U. S. Geol. Survey No. 309, 1907, p. 7. 
pinkish sandstone with a few congıomerate layers. Above this is 340 feet of heavy-bedded, coarse yellowish granitic sandstone; then 330 feet of heavy-bedded granitic sandstone, locally pinkish in color; and, finally, 950 feet of medium-bedded, characteristic reddish-brown siliceous conglomerate and coarse sandstone, with minor amounts of clayey shale. The upper horizon has 1,815 feet of thin to thick beds of characteristic brownish-red clayey shale with minor amounts of sandstone and conglomerate, the whole becoming lighter colored toward the top, and about 575 feet of light-brown shale, with white to pinkish calcareous concretions, these latter beds being transitional into the Vaqueros shale above.

Some of the harder Sespe conglomerate makes excellent road material and is quarried extensively for this purpose at different points along the base of the mountains. Good building stone could doubtless be obtained from the formation at certain localities, although at present the only place where the rock is quarried is in Sespe Canyon, Ventura County.

Age.-No fossils have been found in the Sespe formation in the Summerland district. Watts and Eldridge, from their studies in Ventura County, are of the opinion that the Sespe is largely Eocene, although their evidence for this belief is not conclusive. It is quite probable that the base of the formation is Eocene, as characteristic Eocene forms have been found in the top beds of the Topatopa formation, which conformably underlies the Sespe. It seems possible that at least a part of the Sespe is Oligocene, for it grades at the top into beds which at several localities are known to contain lower Miocene fossils.

Distribution and structure.-The Sespe formation is exposed almost continuously from the type locality in Sespe Canyon at least as far west as Santa Barbara, and probably much farther. What is thought to be an outcrop of the Sespe is also exposed in the core of the anticline of Vaqueros sandstone south of Santa Ynez, nearly 40 miles west of Santa Barbara. In the Summerland district the Sespe lies stratigraphically above the Topatopa, with which it is conformable, forming a band averaging about a mile in width immediately south of that formation at the base of the Santa Ynez Range. North of the eastern part of the city of Santa Barbara the band of Sespe deposits is affected by the overturn and dips northward at steep angles under the older Topatopa beds; north and northwest of the Mission the beds occupy their normal relation to the Topatopa and dip toward the south. The belt of Sespe at the base of the range northeast of Summerland lies in a syncline overturned toward the south; farther east, however, this syncline rights itself and extends as a broad trough as far east as the Ojai Valley. 
Another band of the Sespe occupies the flanks of the ridge between Toro Canyon and the east end of the area shown on the map; it also extends westward from Toro Canyon, forming a large part of the group of hills immediately northeast of Summerland. In this band the Sespe dips south at a steep angle, its base being determined by exposures of the underlying Topatopa, while its upper beds are for the most part hidden under the Pleistocene deposits of the lowland: A little isolated outcrop of Sespe forming the two knoHs in the bend of Ficay Creek, $1 \frac{1}{2}$ miles northeast of Summerland, is a part of the uppermost light-brownish shale of the formation. As this exposure lies in the direct line of strike of the basal sandstone beds of the Sespe outcrop in the ridge immediately to the southeast, it is very evidently separated from the beds in the ridge by a profound fault, with a downthrow on the north.

Evidences of petroleum.-No evidences of petroleum were found by the writer in the Sespe beds in the Summerland district. However, the same formation is petroliferous in the region of Sespe and Sisar canyons, farther east, and it is said that certain indications of oil have been found by others in the Sespe northeast of Summerland. The well of the Pinal Oil Company, on the west side of Arroyo Parida, starts down in the basal sandstone of the Sespe, but it is thought that this well was located with the intention of tapping the shales at the top of the Topatopa formation, which lies just below, rather than with the idea of obtaining oil from the Sespe.

\section{VAQUEROS FORMATION.}

Name and correlation.-The name Vaqueros was proposed by Homer Hamlin for a characteristic sandstone formation underlying the Monterey shale in Los Vaqueros Valley, Monterey County, and was first used by H. W. Fairbanks ${ }^{a}$ for the lower Miocene of the San Luis quadrangle. Owing to its characteristic fauna, the formation has been recognized over much of the Coast Range belt. Although what is called the Vaqueros formation in the Summerland district contains no characteristic fossils, its stratigraphic position and lithologic similarity to certain characteristically fossiliferous beds in the Ojai Valley to the east leave no doubt in the mind of the writer as to its correct correlation.

Lithologic character.-The basal portion of the Vaqueros consists of several beds of fine to coarse, more or less arkose, light-brownish sandstone, interbedded with minor quantities of dark earthy to sandy shale, about 785 feet in all. This sandy zone is apparently somewhat more resistant to weathering than the shale above, as is indicated by its presence in the row of knolls one-half mile northeast of Summerland. Above the sandy zone and grading into the overlying Monte- 
rey shale is about 1,650 feet of grayish clayey shale, with many layers of gray to yellow calcareous shale or calcareous concretions; the shate is darker colored toward the top and apparently less sandy than lower down. The whole shaly portion of the formation weathers into black adobe soil, in which the hard lime concretions are abundant; the sandy portion of the Vaqueros produces a lighter colored soil than the shale.

The Vaqueros in this district contains little of the coarse sandstone which is so characteristic of the formation in the region at the west end of the Santa Ynez Range. In this respect it is like the Vaqueros of the Sespe and Ojai regions, which is made up largely of shale.

No indications of petroleum were noticed by the writer in any of the exposures of the Vaqueros in the Summerland district.

Distribution and structure.-The Vaqueros fine sandstones and shales lie conformably above the light-colored shale of the Sespe formation in the region north of Summerland and also north and northwest of Santa Barbara. In the Summerland area the beds vary in dip from $70^{\circ}$ to $90^{\circ} \mathrm{NW}$., with a strike of northwest-southeast. In the region north of Santa Barbara the same beds appear to be overturned and dip steeply northward, with a west-northwest strike parallel to the major structural features of the range.

\section{MONTEREY SHALE.}

Name.-In 1855 William P. Blake ${ }^{a}$ described the diatomaceous shales in the vicinity of Monterey and applied to thern the name that has been accepted ever since by west-coast geologists to designate the characteristic shale formation of the middle Miocene, which has so widespread a distribution in the Coast Ranges of California.

Lithologic character.-As in many portions of the Coast Ranges, the Monterey in the Summerland district is in general distinguished by its diatomaceous character. Unusually pure diatomaceous earth, or tripoli, as it is sometimes called, is found in the areas of Monterey adjacent to Sycamore Canyon and southwest of Montecito. These deposits have been the subject of a special paper by Finch. (See p. 13.) Similar deposits in the northern part of Santa Barbara County are described by the writer and Robert Anderson in "Contributions to Economic Geology for 1906." $b$ This diatomaceous earth usually contains from 70 to 85 per cent of silica, is white to light-yellowish in color, very light in weight, and fairly resistant to weathering. The siliceous shells of the individual diatoms are usually distinguishable under a lens in most hand specimens of this material.

In the region of the Carpinteria asphalt quarry the shales are highly bituminous, and have assumed contrasting alternations of 
black, brown, and white, which are rendered more conspicuous by the action of the waves. Along the railroad immediately east of the area shown on the map the shale is interbedded at rare intervals by 4 -inch to 24-inch, fine, brownish, more or less bituminous sandstone layers.

Volcanic ash occurs at two horizons toward the base of the Monterey northwest of Summerland, as shown on the map (Pl. I, p. 18). The lower deposit is about 125 feet and the upper about 75 feet in thickness. The lower is slightly coarser grained than the upper. The ash is white and very gritty, and consists largely of angular grains of quartz and lath-shaped feldspar crystals, some more than 2 or $3 \mathrm{~mm}$. in length.

The Monterey shale becomes strongly porcelaneous in the area northwest of the Santa Barbara Mission, and in some places even approaches a flint in texture. The beds here are harder than any others occurring in this formation in the district.

The following log shows the character of the Monterey in the hills immediately north of Summerland:

Log of well in Monterey formation one-third mile north of Summerland Station.

\begin{tabular}{|c|c|c|c|c|c|}
\hline . & $\begin{array}{c}\text { Thick- } \\
\text { ness. }\end{array}$ & Depth. & . & $\begin{array}{l}\text { Thick- } \\
\text { ness. }\end{array}$ & Depth. \\
\hline 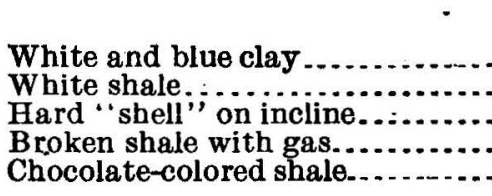 & $\begin{array}{r}\text { Feet. } \\
50 \\
50 \\
1 \\
1 \\
17 \frac{1}{2}\end{array}$ & \begin{tabular}{c||} 
Feet. \\
50 \\
100 \\
101 \\
$102 \frac{1}{2}$ \\
120
\end{tabular} & 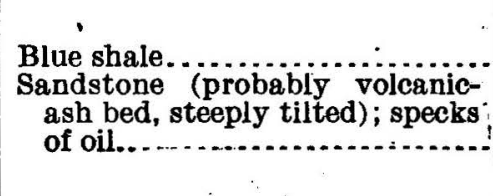 & $\begin{array}{r}\text { Feet. } \\
80 \\
300\end{array}$ & $\begin{array}{l}\text { Feet. } \\
2000\end{array}$ \\
\hline
\end{tabular}

Salt water below sea level in this well.

Age and fossils.--Recognizable marine molluscan fossils were found in the Monterey at only one locality in the district. This was on the south face of the 675-foot hill just east of Diablo Canyon and a little more than a mile northwest of the Mission. Here the semiporcelar neous shale and an interbedded fine sandstone layer yielded the following fossils: Arca sp. (small), Pecten peckhami Gabb (abundant and beautifully preserved as casts; Pl. X, fig. 10), and Phacoides sp. (small, gibbous).

Distribution and structure.-The Monterey formation occupies a belt lying conformably above the Vaqueros in front of the whole length of the Santa Ynez Range in the Summerland district. Over much of the territory the shale is covered by the Pleistocene deposits, but at certain localities erosion has stripped the beds clear of their overlying mantle and they are shown in all their complexity of structure. Beautiful sections are disclosed in the sea cliff for many miles southeast of the mouth of Carpinteria Creek (see Pl. III, $A$ ), while west of Punta del Castillo and Santa Barbara Point there are other 


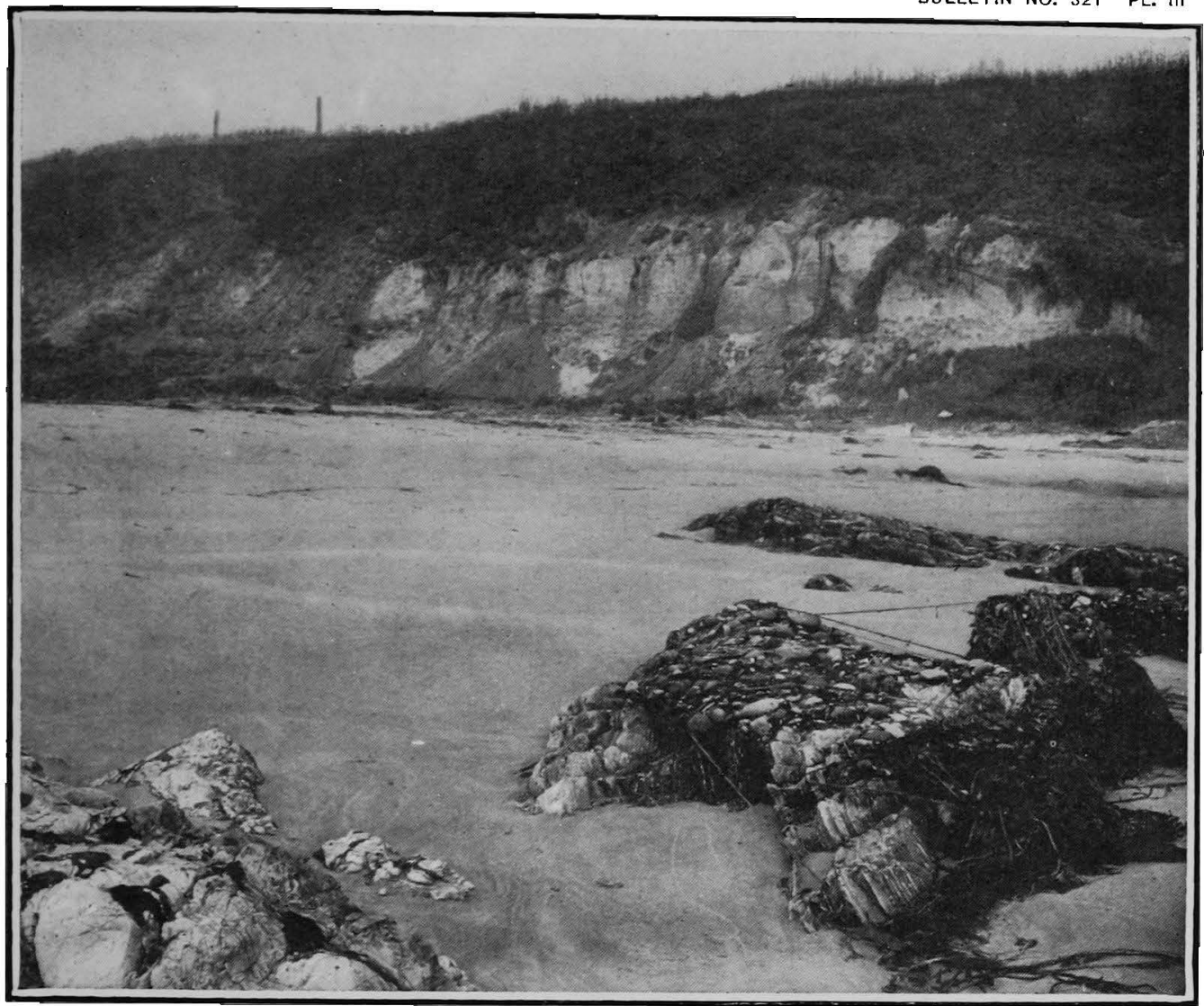

1. BEACH NEAR CARPINTERIA ASPHALT MINE, SHOWING UPTURNED AND CONTORTED MONTEREY SHALE.

The exuding tar cements seaweed, pebbles, and rocks into a firm conglomerate. Eluff in rear Is composed of sands heavily impregnated with asphaltum.

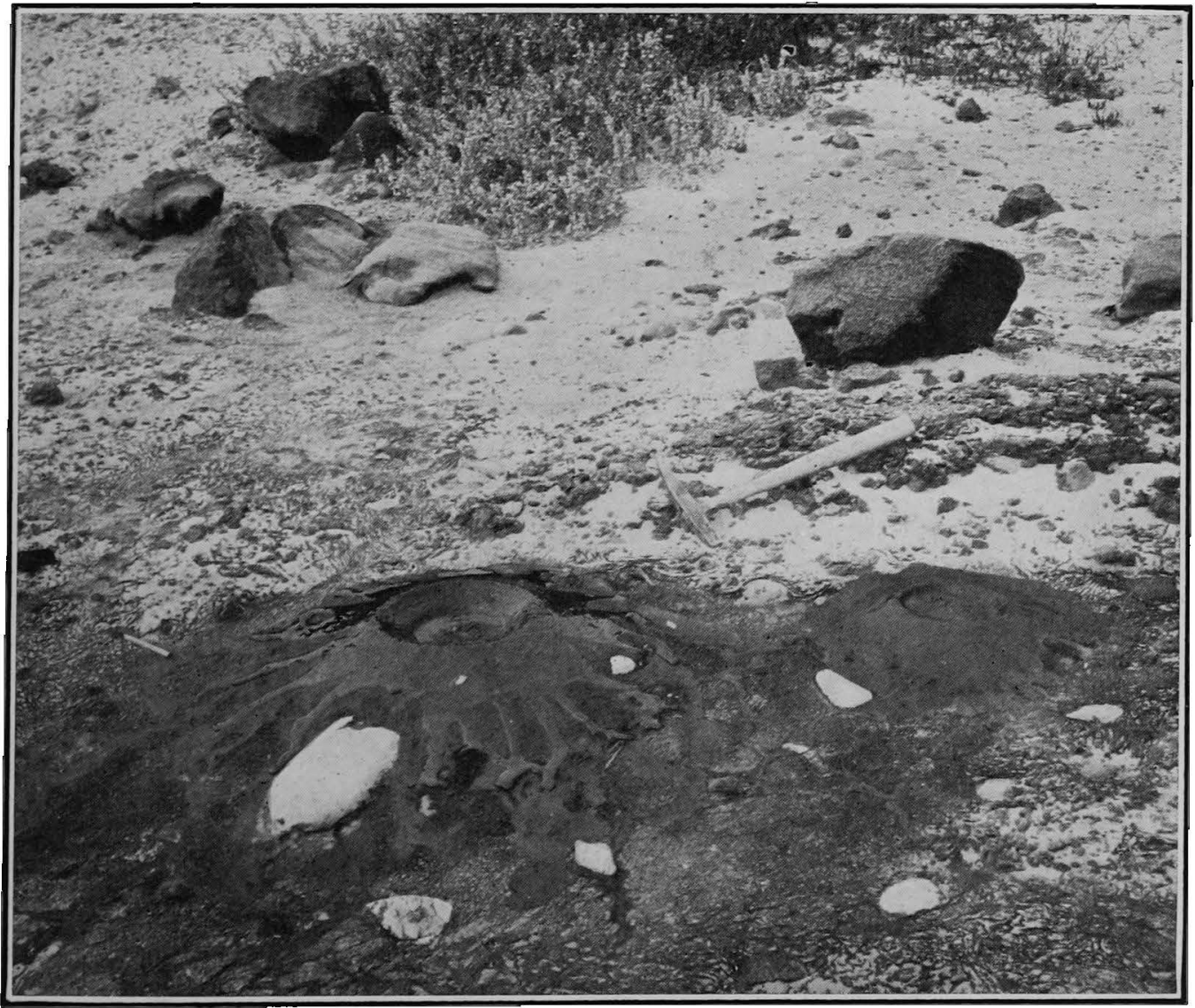

B. A TAR VOLCANO IN THE CARPINTERIA ASPHALT MINE.

Showing how oil exudes from joint cracks in the upturned Monterey shale forming the floor of mine. 

excellent exposures. North of Summerland and north of Santa Barbara are isolated patches of this formation.

In the western part of the district the shale dips northward at angles of $40^{\circ}$ to $90^{\circ}$, being affected by the overturn which controls the position of the beds in the Santa Ynez Range; north of Summerland it dips steeply to the southwest, while at the asphalt quarry at Carpinteria it stands exactly vertical, changing, however, to a northeasterly dip farther east along the coast. Toward the east edge of the area mapped the shale is folded into an anticline striking a little north of west, with dips of $30^{\circ}$ on its northeast flank and $45^{\circ}$ on its southwest flank, near the axis. The shale is much contorted and fractured locally, especially in the region along the coast half a mile east of Carpinteria. The well of the Columbia Oil and Asphalt Company, 1 mile southwest of Carpinteria, is located near the axis of this anticline.

Evidences of petroleum.-The Monterey shale is probably the ultimate source of most of the oil occurring within this and most of the other. productive oil fields of the Coast Ranges. The petroleum is thought to be the product of a slow and complicated process of metamorphism and distillation affecting the hydrocarbon material in the diatoms and other organic remains which play so prominent a rôle in the formation of these shales. This subject is more fully discussed in Bulletin No. 322 of the United States Geological Survey.

In the vicinity of the Carpinteria asphalt mine and to the southeast along the shore for about a mile the shale is very petroliferous, tar oozing from the joint cracks at many places. This substance not only forms black coatings over the exposures on the beach, but cements sea weed, shells, and pebbles into a firm conglomerate which forms a layer over the rocks near the water. (See Pl. III, A.) Deposits of asphaltum are formed from the oil or tar which exudes from the shales and penetrates the overlying Pleistocene sands. Pl. III, $B$, shows a characteristic seepage of oil from the Monterey shale forming the floor of the Carpinteria asphalt mine. Wells drilled in the shales in this vicinity also yield small amounts of heavy oil. This occurrence of petroleum in the shale is associated with a zone of fracture and a fold parallel to this zone, affecting the Monterey along this part of the coast.

At many places west of Santa Barbara as far as Gaviota the Monterey shales exude oil and tar, some localities furnishing asphalt in commercial quantities ${ }^{a}$ Wells in the Summerland field which penetrate the Monterey usually strike small quantities of gas, but no oil worthy of mention.

With the exception of the exposures along the coast the surface evidences of petroleum in the Monterey are not noteworthy. Certain 
shales exposed in the Arroyo de las Ortegas, northwest of Summerland, show some signs of petroleum, as do the shales in one or two other exposures farther west, but these are of little importance.

\section{FERNANDO FORMATION.}

Name.-The name "Fernando" was used on a manuscript map by Homer Hamlin several years ago to specify a certain formation containing Pliocene fossils and unconformably overlying the Monterey shale in the San Fernando Valley, Los Angeles County. It has since been used by Eldridge and Arnold ${ }^{a}$ to designate the same formation throughout the oil fields of Ventura, Los Angeles, and Orange counties, and still more recently by Arnold and Anderson ${ }^{b}$ for an equivalent formation in northern Santa Barbara County.

Lithologic character in the Summerland area.-The Fernando, in the region east of Santa Barbara, consists of clay and clayey shale, sandstone, and conglomerate. The last two contain oil toward the base of the formation over much of the territory south and southeast of Summerland.

Clayey shale appears to comprise something like 400 feet of strats at the base of the Fernando in the Summerland region. Some exposures of this shale occur in a cut on the north side of the county road in the eastern part of the town, and also at two places along the beach between the easternmost Duquesne wharf and Loon Point. The shale is rather soft, gray to brown in color on fresh surfaces, but rusty in the joint cracks, of which there are many cutting the rock. Gypsum occurs in numerous small veins in the outcrop on the county road, and gypsum and sulphur both are abundant in the outcrops along the beach. Sandy clay shale and bluish and grayish clay are also interbedded with the sandstones and conglomerates, which overlie the basal shale. The clays usually slack on exposure. The gypsiferous sandy clay shale exposed in the bluff opposite the cemetery 1 mile north of Montecito Landing probably represents a zone higher up in the formation than the similar beds at Summerland.

Sandstone and conglomerate with some interbedded clays make up the upper portion of the Fernando, the coarse sediments being composed largely of waterworn Eocene sandstone with scattered pebbles of quartzite and other hard rocks. (See Pl. IV.) From one-eighth to one-half mile west of the westernmost Summerland wells the formation is very conglomeratic, and contains bowlders up to 2 feet in diameter, the average, however, being under 6 inches. The pebbls bodies are incoherent and form strata and great irregular masse. Fine yellowish to pinkish sands and one or two streaks of dark-grar clay are interbedded with the conglomerate at this locality. At the 


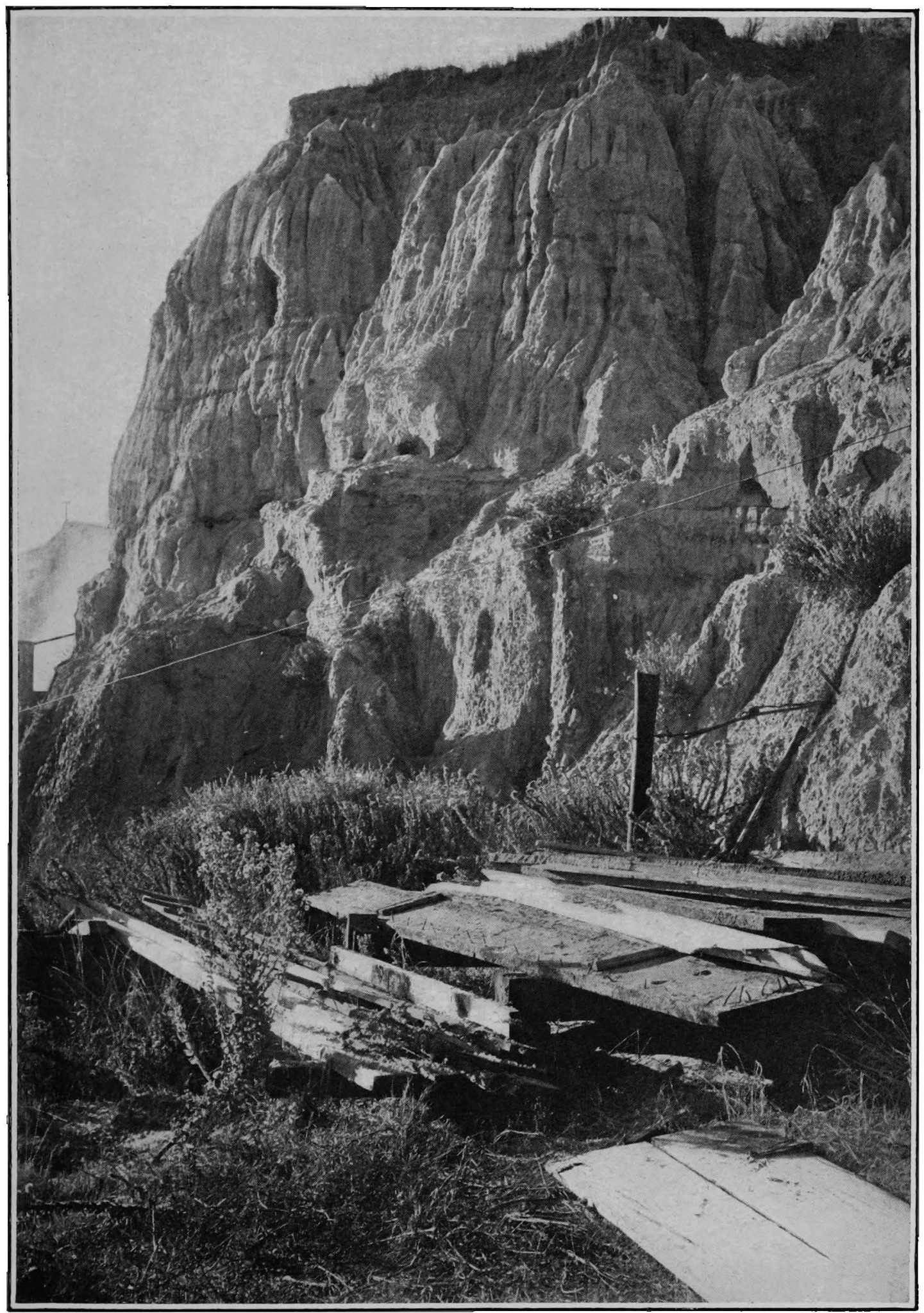

UNCONFORMITY NEAR NORTH STAR WHARF. LOOKING WEST.

Pleistocene deposits resting : ?early vertical oil-bearing Fernando sandstone and conglomerate. 

west end of the field the beds are lower in the formation than those just described, but closely resemble them. Larger bowlders, some up to 4 feet in diameter, occur in these lower beds, and interstratified blue clays become more abundant as the base of the formation is approached. Evidences of petroleum are first encountered in that part of the formation exposed in the railroad cut near the westernmost wells, in the sandy and conglomeratic layers, and from this horizon down (stratigraphically) for over 200 feet the beds are more or less petroliferous. The oil-bearing strata are also encountered near Loon Point, where they consist of yellowish to reddish sandstone and conglomerate. Similar rocks outcrop in the bluffs 1 mile north of Montecito Landing.

Lithologic character in the Santa Barbara area.-The Fernando formation in Packards Hill southwest of Santa Barbara, consists of fossiliferous sandy marl, sandstone, and sandy shale dipping slightly west of south at angles varying from 15 to 45 degrees. In the bluffs at the eastern end of the hill, near the bath house, the formation consists largely of bryozoan marl and sandstone, certain layers being exceedingly fossiliferous. The more fossiliferous layers are much the harder, and form protruding shelves along the face of the bluff. ${ }^{a}$

Age and fossils. - No fossils have been found in the Fernando formation in any of the outcrops at Summerland, Loon Point, or Montecito, but in the area southwest of Santa Barbara an abundant marine fauna representing two horizons is present.

The fossiliferous beds are certainly of marine origin, and are known to represent horizons in the body of this formation; the beds in the Summerland areas are of unknown origin, but are undoubtedly at the base of the Fernando and rest on beds of middle Miocene (Monterey) age. The fossil-bearing strata are certainly Pliocene, and may extend over into the Pleistocene, so that it is probable that the lower or unfossiliferous part of the formation is either lower Pliocene or upper Miocene.

a Mem. California Acad. Sci., vol. 3, 1903, pl. 31, fig. b.

1783-Bull. 321-07-3 


\title{
The following species have been found in the marine beds southwest of Santa Barbara:
}

\author{
Fossils collected from the Fernando formation at Santa Barbara.a
}

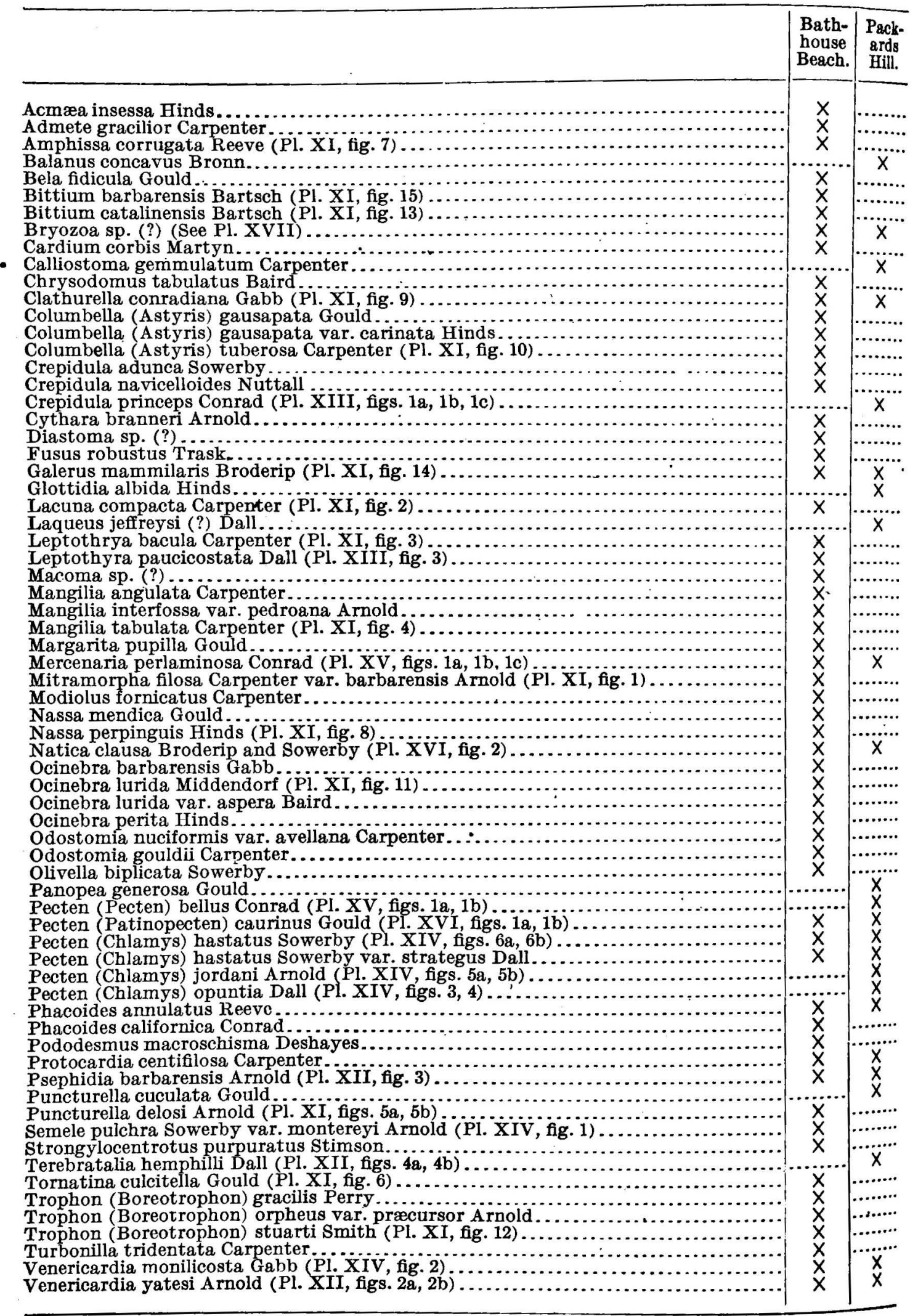

a Mem. California Acad. Sci., vol. 3, 1903, p. 52.

Distribution and structure.-Only a very small percentage of the ares discussed in this report is occupied by the Fernando, but as it is the 
formation that contains the productive oil sands of the Summerland field it is one of the most important. The contacts of this formation with those adjacent, as shown on the map, are at nearly every place arbitrarily determined, owing to the soft composition of both the Fernando and the Monterey and the similarity of the overlying Pleistocene deposits to the Fernando. Three general areas are shown on the map. That at Summerland borders the coast and is affected by one or more irregular, undulating anticlines which parallel in a general way the other structural lines of the region. Another small area, also lying in an anticlinal position, is exposed in the bluff 1 mile west of Montecito Landing. The third and most important district occupies Packards Hill, southwest of Santa Barbara, where the formation lies in a great southwestward-dipping monocline at least as far as the middle of the area. This outcrop was not studied in detail, so that its relations to the Monterey shale, which borders it along the coast on the southwest, are not known.

Evidences of petroleum. - Surface indications of petroleum, in the form of chocolate-colored bituminous sandstone, appear at Loon Point at intervals for one-half mile to the west, and also along the cliffs at the west end of the field. The uppermost bed that shows signs of impregnation occurs in the railroad cut a short distance west of the westernmost Southern Pacific well on the bluff. (See Pl. VI, p. 36.) The strike of this bed and its associated conglomerates (which are locally called "the reef") would carry it to the southeast, toward the end of the Southern Pacific wharf. No productive wells have been found southwest of the submarine outcrop of this reef bed. Although similar to the Loon Point Fernando beds, and occupying structurally an apparently analogous position, the sandstone and conglomerate exposed in the anticline 1 mile west of Montecito Landing yield no indications of oil. Neither does the marine Fernando west and southwest of Santa Barbara. A discussion of the productive oil sands which occur in the Fernando is given under the heading "Dedescription of the wells" (pp. 39-49).

\section{PLEISTOCENE DEPOSITS.}

Lithologic character.- The Pleistocene deposits in the Summerland district are of several kinds and include detrital accumulations, marine beds, and certain sandy clays of uncertain origin. The detrital deposits are incoherent and consist of poorly assorted material, ranging in texture from fine sand to great bowlders of the Eocene sandstone 10 or 12 feet in diameter. This material has been brought down from the mountains by the streams during periods of flood and spread out on the slopes at the mouths of the steep canyons. The presence of the huge bowlders on the slopes of Mission Ridge and at other places at 
least a mile from the mouth of the nearest canyon implies a tremendous carrying power for the depositing stream.

The beds exposed in the bluffs along the shore extend inland for an indefinite distance, probably as far as the inner margins of most of the terraces, and are composed of gravel and sand with which finer sediments are locally interbedded. (See fig. 2; also more particularly $\mathrm{Pl}$. II, $B$, and Pl. IV, p. 30.) Extreme variation takes place abruptly not only in the vertical succession, but also in individual layers, which at many places vary conspicuously in thickness and in composition within short distances, sand replacing gravel, and clay locally taking the place of sand, and vice versa. Bituminous sands and gravels occur at the base of the Pleistocene in certain areas, such as at Summerland and Carpinteria, and flowing water is struck at the same horizon in the region of

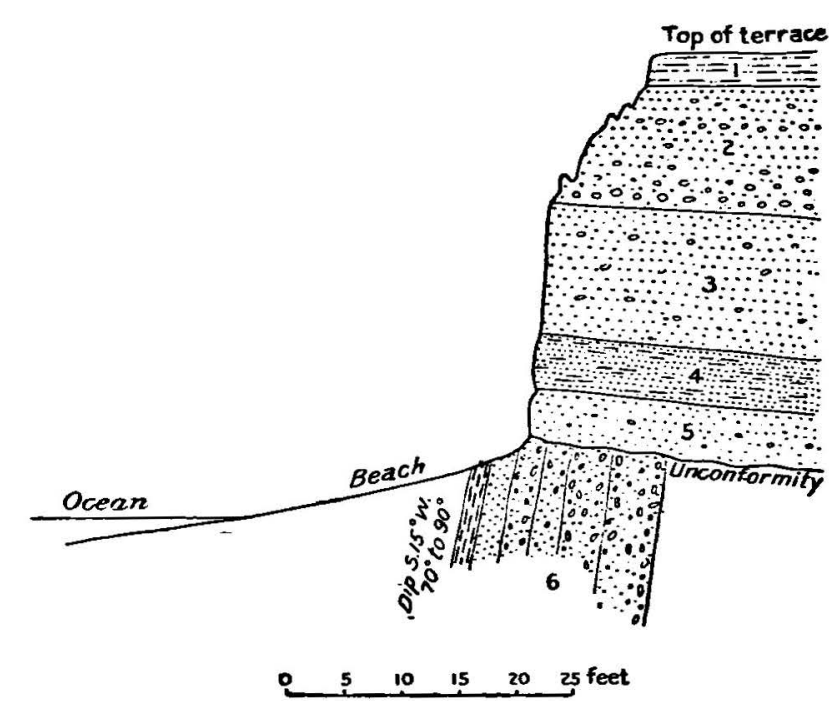

FIG. 2.-Detailed section of bluff near North Star wharf. Pleistocene: 1, Dark-brown soil; 2, drab clayey sand and conglomerate; 3 , yellow quartzose and feldspathic sand, with distributed pebbles; 4 , fossiliferous fine compact sand and clay; 5 , brown bituminous sand, some sandstone pebbles. Pliocene: 6, Gray shale, sandstone, and conglomerate.
Carpinteria Creek. Oil and water are encountered in wells near Serena at depths of 25 to 100 feet in what is supposed to be the basal Pleistocene gravel.

The basal beds of the marine Pleistocene are fossiliferous at Summerland, at Carpinteria, and north of Montecito Landing, the latter locality yielding a good fauna from a bed 1 to 2 feet thick. The species are those still found living in adjacent waters. In the Carpinteria asphalt mine the two
Conrad and Petricola candirock-boring mollusks Pholadidea penita Conrad and Petricola cant
toides Conrad are particularly abundant in the floor of the mine, which was once the top of the Pleistocene terrace.

In the lowlands along the Santa Barbara, Montecito, and Summerland roads occurs a formation of sandy clays, blue to yellowish in fresh cuts, that is very tenacious and more or less porous from the apparent rotting of contained vegetable matter, etc., and there fore resembles loess. The beds carry small pebbles, which are derired from the adjoining mountain slopes. The formation lies flat and is apparently undisturbed. It is thought possible that these beds are of fresh or brackish water origin, although no fossils or other diret evidence have been found in support of this theory. 
Distribution.-The Pleistocene deposits cover a large part of the mapped area, hiding the older formations over most of the lowlands south of the main range. The detrital deposits are probably the most important and cover the slopes contiguous to the base of the mountains; those of marine origin skirt the coast and cover the old terraces; while the clays and fine sands, which are believed to be of fresh-water or possibly brakish-water origin, lie in the region between Santa Barbara and Summerland.

The Pleistocene beds vary materially in thickness from point to point, at one place forming a thin veneer over the older rocks and at another, as in the area east of Carpinteria Creek and for a mile from the ocean, being about 150 feet thick. This last-described area occupies an old basin or valley, probably the abandoned channel of Rincon Creek. In the northern part of the Summerland field the Pleistocene is over 50 feet thick.

- Evidences of petroleum.-Bituminous sand and gravel, deriving their hydrocarbon contents by infiltration from the underlying formations, are found in the Pleistocene at many localities along the coast from Goleta to Rincon Creek. In some places these have been worked for the asphalt; in others the degree of impregnation of the sands has been so slight as to preclude their profitable exploitation. The asphalt deposits have been described by Eldridge ${ }^{a}$ and others, and the Summerland occurrences only will be mentioned here.

The basal Pleistocene layer in the bluff opposite the northern part of the town consists of chocolate-colored to brown bituminous sand containing a few sandstone pebbles. The bed varies in thickness from 4 or 5 feet to more than 10 feet, thickening toward the west but finally disappearing opposite the western wells of the field. Here it abuts against the steeply dipping Fernando conglomerates of Ortega Hill, which protrude over it, thus implying its deposition at this point in a wave-cut cave. The beds dip toward the northeast at angles up to $8^{\circ}$ or $10^{\circ}$, and for this reason have been erroneously correlated by some operators with the Fernando beds, which dip steeply southwestward (see fig. 2, p. 34). The bituminous sand is so heavily charged in certain places in the Summerland field that some fresh exposures of it are said to have yielded considerable oil. Weathered surfaces, by a loss of the more volatile constituent of the oil, dry out and seal up the inner portions.

An oil spring is mentioned by Watts ${ }^{b}$ as being exposed at low tide on the seashore one-fourth of a mile southwest of Martin's ranch, Serena. 


\section{STRUCTURE.}

\section{GENERAL STRUCTURE OF THE DISTRICT.}

The great overturned anticline previously referred to as elevating the main portion of the Santa Ynez Range is the dominant structural feature of the region, although there are in addition to this one an important faulted anticline northeast of Summerland, some complex folds in the range north of Santa Barbara, and several other minor flexures and zones of disturbance near the ocean. The reader's attention is called to the sections (Pls. V, VII, $A$, and VIII) and the contour map.(Pl. VI), as elucidating the statements made in the following paragraphs:

SANTA YNEZ RANGE ANTICLINE.

The great anticline of the Santa Ynez Range is believed to be the westward continuation of the overturned anticline which affects the rocks of the Topatopa Range north of the Ojai Valley 15 miles east of the Summerland district. Throughout its extent it trends practically in an east-west direction. From some undetermined point west of the Ojai Valley westward nearly to the intersection of Steer and Eldorado creeks, something over a mile east of the east edge of the area covered by the map (PI. I, p. 18), the anticline is normal and its south flank dips southward at angles ranging from $30^{\circ}$ to $90^{\circ}$. From the intersection of the creeks just mentioned westward at least as far as Montecito and probably farther the anticline is again overturned, the south flank of the fold dipping to the north at angles varying from $40^{\circ}$ to $90^{\circ}$ (see section $C-C^{\prime}, \mathrm{Pl}$. V). In the region west of Montecito Peak the structure becomes more or less complex, although it is certain that the overturn, so.far as it affects the Sespe and younger formations, extends practically to the west edge of the area mapped (see section $A-A^{\prime}, \mathrm{Pl}$. V). In the region of Sycamore Canyon the Monterey (middle Miocene) shale has been so far over turned as to dip $40^{\circ}$ or even less toward the north. These dips in th shale, however, may possibly be due to local crumpling.

\section{ARROYO PARIDA ANTICLINE AND FAULT.}

The range of hills northeast of Summerland was elevated by an anticline which later became faulted at its apex. This anticline vi be referred to as the Arroyo Parida faulted anticline, as it pass along the canyon of Arroyo Parida for some little distance (see Pl. T section $C-C^{\prime}$ ). The fault exposes on its south side upper Topatof sediments dipping steeply southward at angles as high as $70^{\circ}$, ore lain by later formations with dips fully as steep, if not locally steept The lowest beds exposed on the north side of the fault are the proil nent thick-bedded light sandstones at the base of the Sespe, whit 


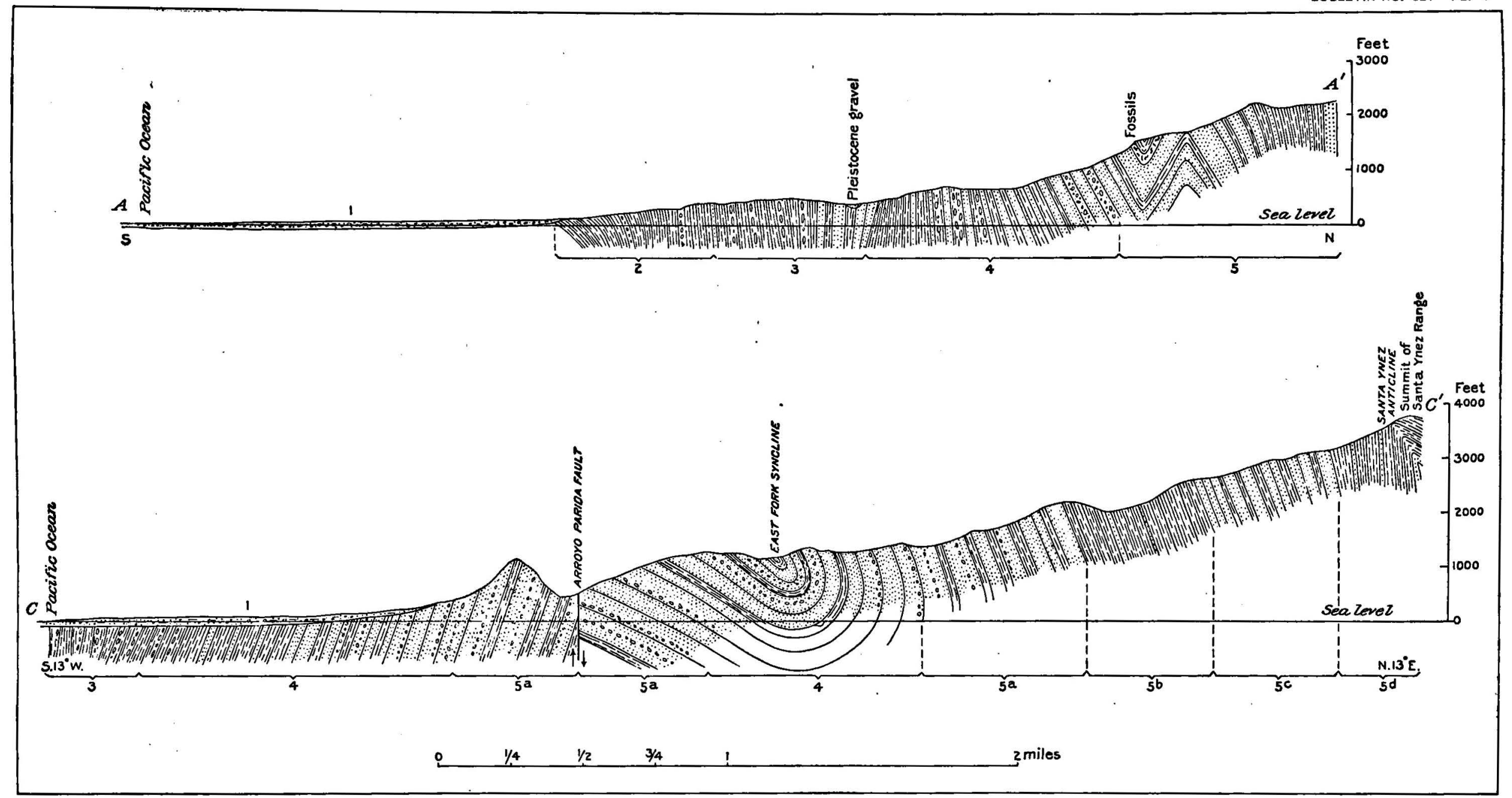

GEOLOGIC SECTIONS ON LINES $A-A^{\prime}$ AND $C-C^{\prime \prime}$ OF PLATE I.

$A-A^{\prime}$, From coast three-fourths mile east of Santa Barbara wharf northward to ridge east of Rattlesnake Canyon.

$-C^{\prime}$. From coast 1 mile southeast of Serena N. $13^{\circ}$ E. to summit of Santa Ynez Range. 1. Alluvium and Pleistocene gravel, sand, and clay; 2, Monterey (middle Miocene) diatomaceous shale and volcanic ash; 3, Vaqueros (lower Miocene) shale, sandstone, and limestone concretions; 4, Sespe (Eocene-Oligocene?) reddish conglomerate, sandstone, and shale; 5 , Topatnpa (Eocene) formation; 5a, Upper fossiliferous sandstone; 5b, Upper shale, oil bearing; $5 \mathrm{c}$, Lower sandstone; $5 \mathrm{~d}$, Lower shale. 



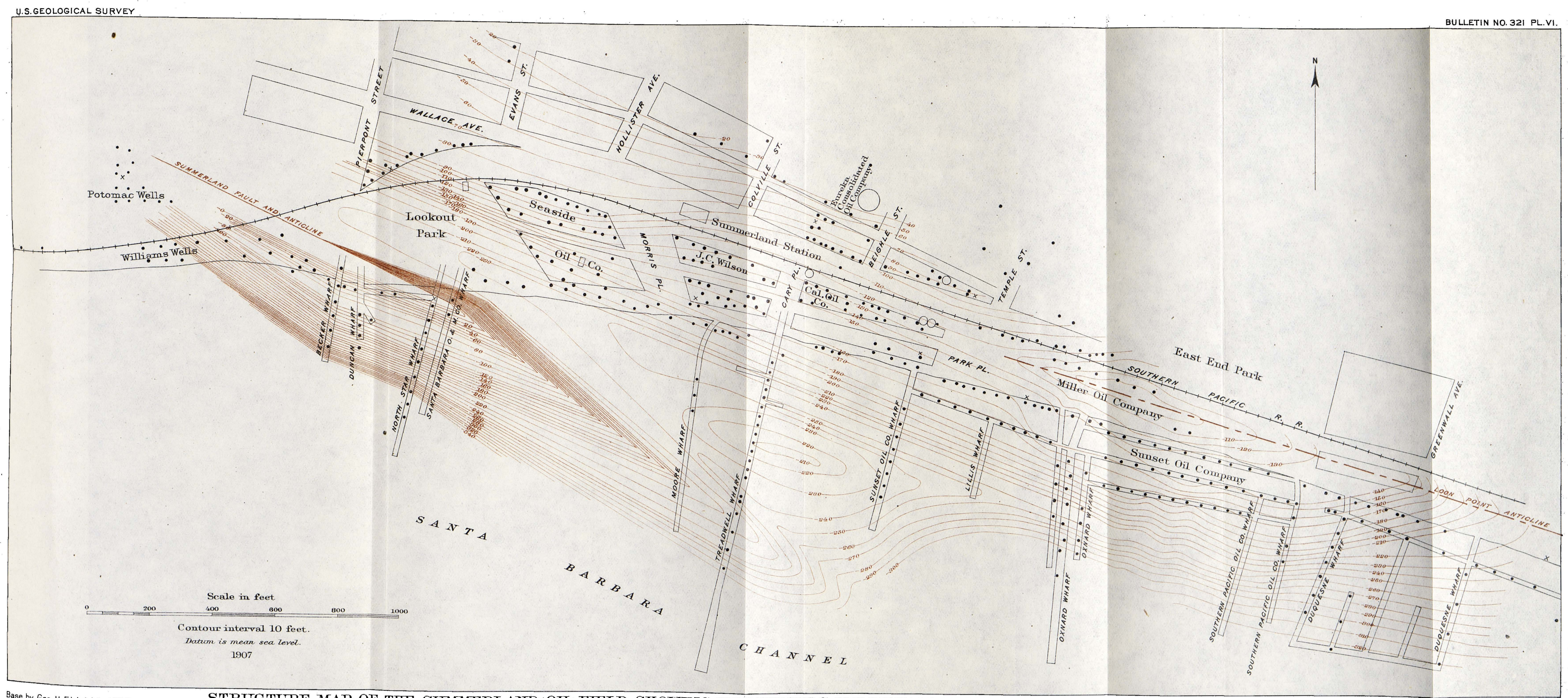



dip at angles of $10^{\circ}$ to $25^{\circ}$ toward the overturned syncline lying between the fault and the Santa Ynez anticline. It is interesting to note in passing that this syncline is traceable for many miles east of the area under discussion and is probably the westward continuation of the syncline which passes through Ojai Valley and to which, in the opinion of the writer, that valley depression owes its origin.

Although the Arroyo Parida fault passes beneath the detrital material west of Toro Canyon, it is known to exist at least as far.west as Ficay Creek. This is shown by the relations existing between the upper Sespe shales in the hills northwest of the bend in Ficay Creek and the lower Sespe sandstones in the ridge only a short distance to the southeast. It is impossible to determine what becomes of the fault still farther west, although where last known it is trending directly toward the complexly folded region north of Santa Barbara, and is believed to bear some relation to the puzzling disturbances in the rocks in the vicinity of Rattlesnake Canyon.

\section{MINOR FOLDS NEAR THE COAST.}

FOLDS EAST OF CARPINTERIA.

An area of complex fracturing and folding stretches along the coast from Carpinteria Creek eastward at least as far as the edge of the region shown on the map. The Monterey shale at the asphalt mine just south of the mouth of the creek is standing vertical; a short distance east of this the same rocks are intricately contorted and fractured, in some places having the appearance of a breccia (see Pl. III, $A$ ); while still farther east, near the edge of the mapped area, an anticline, with northeast dip of $30^{\circ}$ and southwest dip of $45^{\circ}$, passes out into the ocean. East of the anticlinal axis the shale for some distance dips toward the north or northeast. The trend of the anticline is approximately parallel with the coast, and on a line with it, about half a mile east of the asphalt 'mine, an oil well has been sunk.

FLEXURES NEAR. SUMMERLAND.

Two local flexures affecting the oil-bearing Fernando formation have been recognized near Summerland. One of these is a welldeveloped anticline striking west-northwestward from Loon Point, the axis being nearly coincident with the edge of the bluff for more than half a mile northwest of the point. The strike and dip of the exposed beds near the axis indicate that the anticline plunges southeastward and is undulating in the direction of the strike. Points of greater elevation in its trace are 150 yards southeast of the Duquesne wharves and also a short distance west of Loon Point. At these nodes the gypsiferous lower Fernando shale is brought up to view. The dips on the side of the anticline reach as high as $30^{\circ}$ or $35^{\circ}$. The 
flexure gradually dies out from the region of the easternmost group of wharves northwestward toward the main part of the town of Summerland, where it appears to lose its individuality on the southwarddipping flank of the Arroyo Parida anticline.

Another flexure (designated the Summerland fault and anticline on the structure map, Pl. VI), which appears to be a sharp and possibly locally overturned and faulted anticline, with a strike north of west, occurs in the Fernando beds near the edge of the bluff opposite the Becker and North Star wharves. (See section $B-B^{\prime}$ Pl. VII, and the Becker and North Star well sections A, and B, Pl. VIII.) The well logs indicate that this fold covers a rather small area, although its southeastern extension may be considerable. The dips along it range from $45^{\circ} \mathrm{SW}$. to vertical in the Becker-North Star area, the petroliferous sandstones, conglomerates, and associated clays being affected. A disturbance of the Pleistocene beds along what is probably the trace of this anticline tilts them northeastward at angles ranging as high as $8^{\circ}$ or $10^{\circ}$ in the north end of the field. (See fig. 2, p. 34.)

In addition to the two flexures just described, the well logs show one or two local wrinkles affecting the oil sands and associated layers in the region of the wharves; these are shown in the detailed sections and also on Pl. VI.

\section{MONTECITO ANTICLINE.}

An anticline striking about $\mathrm{N} .70^{\circ}$ or $80^{\circ} \mathrm{W}$. passes into the ocean from the bluff opposite the cemetery a mile north of Montecito Landing. This fold affects the Fernando clay, sandstone, and conglomerate. The dip in the beds on either side of the axis ranges from $20^{\circ}$ to $40^{\circ}$, the steepest being toward the southwest. The conditions of structure along the anticline appear favorable for the accumulation of petroleum, and although no surface indications are visible, it is probable that oil-bearing beds underlie the fold, possibly at a considerable depth, however.

\section{STRUCTURE NEAR SANTA BARBARA.}

Detrital deposits obscure the structure in the Santa Barbara Valley, but from the southerly dips in the Fernando beds southwest of the city it is surmised that a fold similar to the Montecito anticline or else \& fault affects the beds of Packards Hill. The structure of the coast west of Punta del Castillo was not studied. 
Ferinando formation, Pliocene and possibly upper Miocene

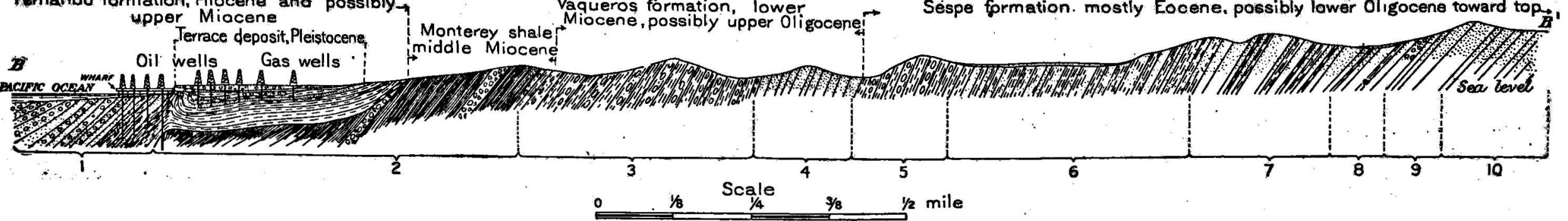

A. GEOLOGIC SECTION ON LINE $B-B^{\prime}$ OF PLATE.I.

5. 12.

From a point northwest of Summerland N. $61^{\circ}$ E. to knoll in forks of Toro Canyon, 2 miles northeast of Summerland.

Surface of Treadwell (Southern Pacific $R$ R Co's) wharf
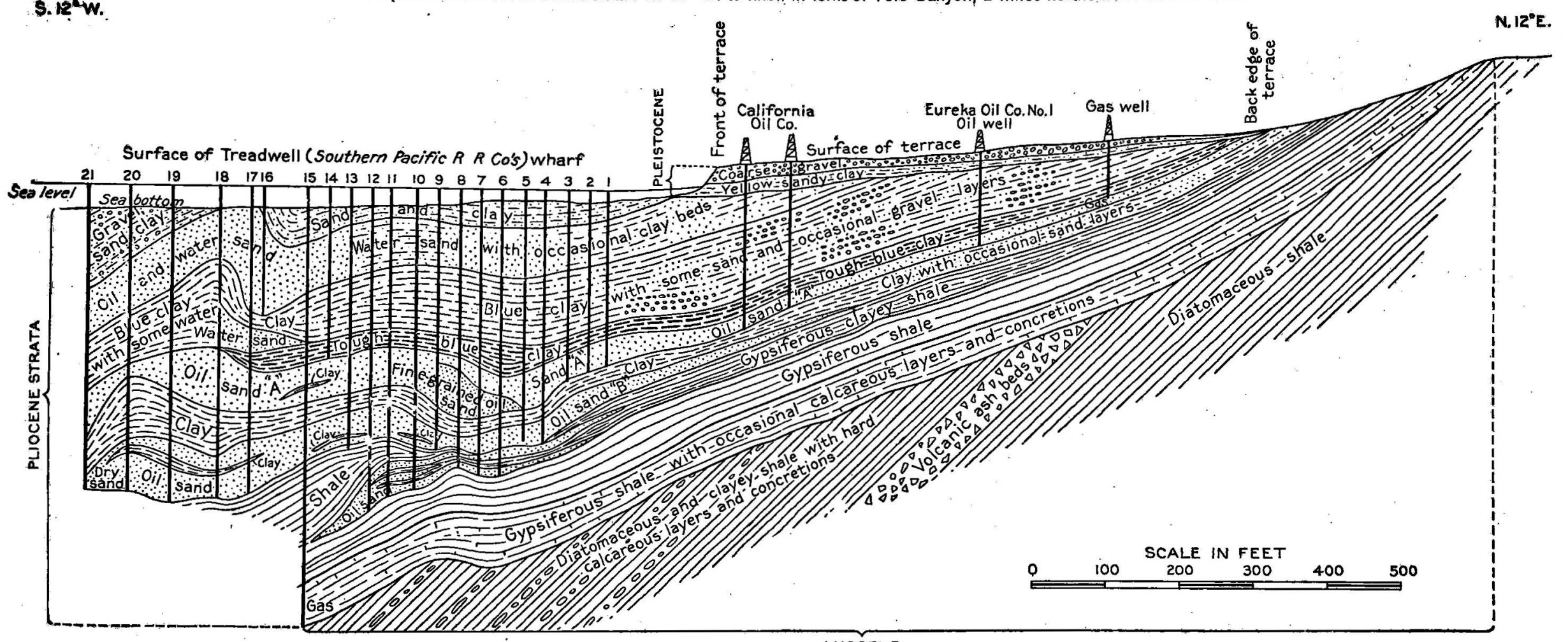

B. SECTION THROUGH TREADWELL (SOUTHERN PACIFIC COMPANY'S) WELLS.

N. $12^{\circ}$ E. to a point immediately northwest of big oil tank in Summerland. Section is about 1,000 feet west of Oxnard wharf. (See PI. VIII, Section C.) 



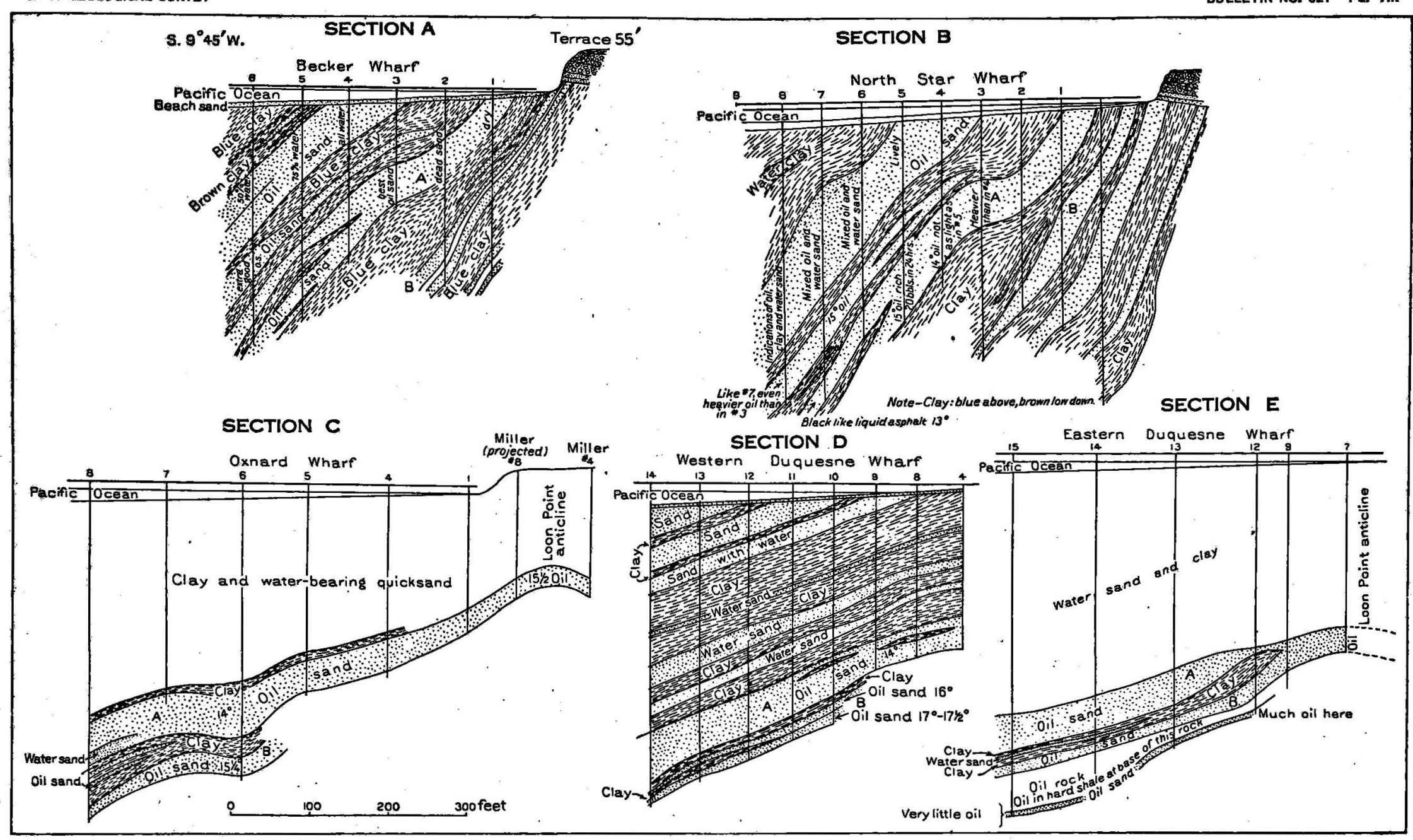

SECTIONS SHOWING RELATIONS OF OIL SANDS IN VARIOUS SUMMERLAND WELLS. A, G. F. Becker Oil Company's ivells Nos. 1 to 6 ; westernmost wharf in the field, about 300 feet west of North Star wharf. B, North Star wharf wells Nos. 1 to 8 ; about 1,100
feet west of Treadwell (Southern Pacific Company's) wharf (see PI VII, B). C, Miller wells Nos. 4 and 8 and Oxnard wharf wells Nos. 1 and 4 to 8 ; about 800 feet west of western Duquesne wharf. D. Western Duquesne wharf wells Nos. 4 and 8 to $14 ; 400$ feet west of eastern Duquesne wharf. E, Eastern Duquesne wharf wells Nos. 7, 9, and 12 to 15 . 



\section{DESCRIPTION OF THE WELLS.}

GENERAL STATEMENT.

The oil wells in the Summerland field are put down on the terrace upon which the town is situated, on the beach in front of this terrace, and on wharves which extend out into the ocean, some of them nearly a quarter of a mile. (See Pl. II, $A$, p. 20.) The wells range in depth from 100 to more than 600 feet, the shallowest being the northernmost on the terrace, the deepest those farthest south on the wharves. The oil is obtained from sands alternating with clay beds in the Fernando formation (upper Miocene or lower Pliocene), which dips almost due south at angles ranging from nearly $90^{\circ}$ at the north end of the field to nearly horizontal at the south end. Only one productive sand, from 10 to 45 feet thick, is penetrated by the terrace wells, but in the wharf wells two, and in some three, oil sands occur.

For convenience of discussion, the field has been divided into the following sections, which are here treated in detail: Area west of Lookout Park; area north of the railroad; area between the railroad and the beach, and wells on the beach and wharves. (See Pl. VI.) In addition to these areas the gas wells in the town of Summerland and the oil wells near Loon Point, near Carpinteria, and in the mountains northeast of Summerland are briefly described.

\section{AREA WEST OF LOOKOUT PARK.}

Geology and structure.--The wells in the area west of Lookout Park - penetrate the steeply dipping or disturbed beds flanking the Sum-merland anticline and fault, which extends from a point a short distance east of the edge of the bluff in the vicinity of the North Star wharf in a northeasterly direction toward the top of Ortega Hill. (See Pl. VI.) Dips of $80^{\circ}$ or $90^{\circ}$ occur in the sandstone and conglomerate beds at the shore end of the North Star wharf, but farther east the dip lowers to $45^{\circ}$ or less. The well logs indicate a more or less irregular arrangement of the Fernando beds in the region of the Potomac wells, probably the result of their proximity to the line of disturbance to which reference has just been made. The strata penetrated consist of gravel near the surface and alternating sands and shale or clay lower down. Several oil sands are penetrated by some of the wells, but only one or two are productive. The productive beds are from 10 to 52 feet thick in the wells and are separated by clay, which varies materially in thickness from well to well. The sand is granitic and coarse textured, some of it approaching gravel, and in most places is "quick" or incoherent, flowing with the oil and necessitating considerable cleaning of the wells. The usual color of the formation in all the wells is brown or gray, but certain wells in 
the triangular block west of Evans street and south of Wallace avenue have yielded a peculiar red material, which has been encountered in no other wells in the field, with the possible exception of some put down in the Monterey shale area in the northern part of the town.

The following two logs illustrate the character of the strata penotrated by the wells in this area:

Log of Williams's well, on top of Ortega Hill, Summerland.

\begin{tabular}{|c|c|c|c|c|c|}
\hline . & $\begin{array}{c}\text { Thick- } \\
\text { ness. }\end{array}$ & Depth. & . & $\begin{array}{l}\text { Thick- } \\
\text { ness. }\end{array}$ & Depth. \\
\hline 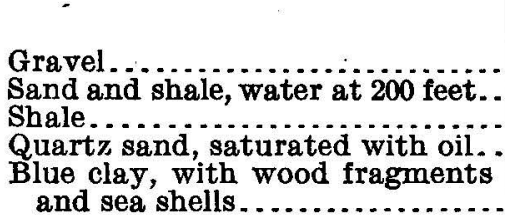 & $\begin{array}{r}\text { Feet. } \\
70 \\
130 \\
115 \\
24 \\
9\end{array}$ & $\begin{array}{r}\text { Feet. } \\
70 \\
200 \\
315 \\
339 \\
\\
348\end{array}$ & 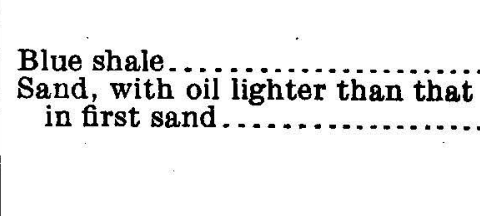 & $\begin{array}{c}\text { Feet. } \\
37 \\
10+\end{array}$ & $\begin{array}{l}\text { Feet. } \\
385 \\
385+\end{array}$ \\
\hline
\end{tabular}

Log of Potomac well, on south Alank of Ortega Hill, Summerland.

\begin{tabular}{|c|c|c|c|c|c|}
\hline & \begin{tabular}{|c} 
Thick- \\
ness.
\end{tabular} & Depth. & & \begin{tabular}{|c|} 
Thick- \\
ness.
\end{tabular} & Depth. \\
\hline $\begin{array}{l}\text { Clay, sand, and coarse gravel. } \\
\text { Dead oil sand.... } \\
\text { Clay } \\
\text { Dead oil sand } \\
\text { Clay } \\
\text { Oll sand with little oil... }\end{array}$ & $\begin{array}{r}\text { Feet. } \\
70 \\
52 \\
38 \\
10 \\
25 \\
11\end{array}$ & $\begin{array}{r}\text { Feet. } \\
70 \\
122 \\
160 \\
170 \\
195 \\
206\end{array}$ & 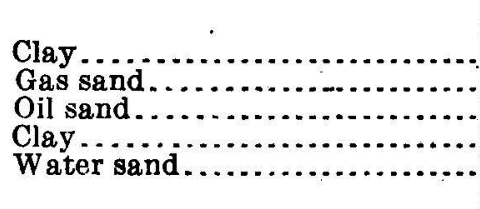 & $\begin{array}{r}\text { Feet. } \\
5 \\
4 \\
20 \\
30 \\
11\end{array}$ & $\begin{array}{l}\text { Feet. } \\
211 \\
215 \\
235 \\
265 \\
276+\end{array}$ \\
\hline
\end{tabular}

Water occurs at several horizons in this area, being encountered at 200 feet in the Williams well (Ortega Hill) and at 265 feet in the bottom of one of the Potomac wells.

Wells.-All the wells in this area are drilled, the casing used being $4 \frac{1}{2}$ inches or a little larger. Productive sands are encountered at depths ranging from about 170 to 385 feet, the latter figure being in the Williams well on Ortega Hill.

Product.-The production ranges from something less than 1 barrel to 2 or 3 barrels a day, but the initial production for some of the wells is said to have been greater. The average for the Potomac group was in 1902 about $1 \frac{1}{4}$ barrels a day each, and it has fallen off but little in the last four years.

The gravity of the oil averages about $15^{\circ}$, varying but slightly above or below this figure. The oil is fairly free from water when the wells are first drilled, but with the lapse of time the proportion of water increases. In 1902 the Potomac wells were yielding 1 to 4 per cent of water and 1 to 2 per cent of sludge with the oil.

Gas accompanies the oil in practically all the wells.

Companies.-Among the companies and individuals who have operated in this area are H. L. Williams, Potomac Oil Company, Roberson Oil Company, Churchill Oil Company, Larson Oil Company, Seaside Oil Company, and Miller Oil Company. 
AREA NORTH OF THE RAILROAD.

Geology and structure.-The oil and gas wells north of the railroad, after passing through the Pleistocene, penetrate the beds near the base of the Fernando which dip at a rather low angle to the south. Beneath the Monterey-Fernando unconformity the Monterey beds probably dip steeply southward, as they do in the hills northwest of Summerland. Some of the drillers, however, have reported steep northerly dips (probably due to local overturning of the beds) in some of the wells in the shale. The Fernando beds dip very gently southward but thin rapidly toward the north, the oil sand decreasing from 25 to 12 feet within 200 or 300 feet.

The well logs indicate from 10 to 25 feet of soil, sand, and gravel (probably Pleistocene); 60 to 120 feet of fine sands and blue clays, with a persistent layer of blue clay at the bottom, and 12 to 25 feet of oil sand, the top of which is penetrated at depths of 70 to 145 feet.

Wells.-With the exception of the Cole dug well, all the wells in this section of the field of which there is any record are drilled, the casing usually being $4 \frac{1}{2}$ inches in diameter.

Product.-When the sand was first tapped the production of the wells ranged from 1 to as high as 12 barrels a day for some of the wells in the central part of this area, but the average at any time was never over 3 or 4 barrels. The Cole dug well, at the extreme east end of the productive territory, 4 feet in diameter and 90 feet deep, yielded but 3 barrels a day. The group of 12 Doulton \& Wilson wells in the central part of the area are said to have averaged 10 barrels a day each in 1895, but fell off to 6 barrels each by July, 1896 .

Companies.-The following are among the companies or individuals who have operated wells in the area north of the railroad: Alameda and Santa Barbara Development Company, Eureka Consolidated Oil Company, Stevens \& Roberts, Doulton \& Wilson, Bachus \& Cravens, Loomis Oil Company, Dewlaney Oil Company, Cole Oil Company, Wakham Oil Company, Goodnow Oil Company, Williams \& Easton, Turner \& Darling.

\section{AREA BETWEEN THE RAILROAD AND THE BEACH.}

Geology and structure.-The conditions in the area between the railroad and the beach are a southward continuation of those found north of the railroad. The terrace on which the wells are sunk averages between 25 and 30 feet above sea level, and is underlain by Pleistocene beds which dip gently northward at the west end of the field but lie flat farther east. Beneath the Pleistocene the Fernando beds show dips ranging from $70^{\circ}$ or $80^{\circ} \mathrm{S}$. in the region about Lookout Park to $22^{\circ} \mathrm{S}$. in the territory of the Seaside Oil Company, 400 or 500 feet farther south, and finally to practically horizontal in the eastern part 
of the field. The wells first penetrate 10 to 20 feet of fine sand and 5 to 10 feet of sand and cobblestones, probably Pleistocene in age. These beds are followed by 150 to 170 feet of sand, with clay and some gravel, a persistent clay bed occurring at the bottom. The oil sand is encountered below the clay bed. It is 30 to 45 feet thick and underlain by clay. The oil sand becomes unproductive in the region a short distance northeast of the shore end of the Oxnard wharf, the eastern of two adjacent wells located here being entirely unproductive while the western once yielded a little oil. The following log of one of the Seaside Oil Company's wells located about 400 or 500 feet east of Lookout Park is typical for this area:

Log of Seaside Oil Company's well 400 or 500 feet east of Lookout Park, Summerland.

\begin{tabular}{|c|c|c|c|c|c|}
\hline & $\begin{array}{c}\text { Thick- } \\
\text { ness. }\end{array}$ & Depth. & & $\begin{array}{c}\text { Thick- } \\
\text { ness. }\end{array}$ & Depth. \\
\hline 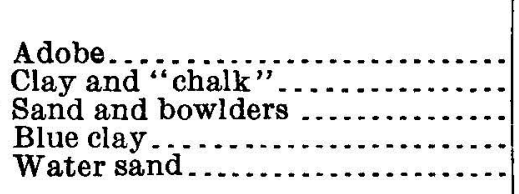 & $\begin{array}{r}\text { Feet. } \\
10 \\
5 \\
50 \\
60 \\
20\end{array}$ & $\begin{array}{r}\text { Feet. } \\
10 \\
15 \\
55 \\
115 \\
135\end{array}$ & 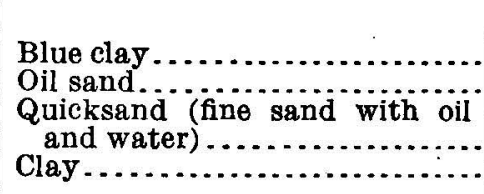 & $\begin{array}{c}\text { Feet. } \\
20 \\
30 \\
20 \\
1+\end{array}$ & $\begin{array}{l}\text { Feet. } \\
155 \\
185 \\
205 \\
206+\end{array}$ \\
\hline
\end{tabular}

Water is encountered in the sand above the clay layer overlying the oil sand, and also in the fine sand underlying the oil sand. At this lower horizon it is associated with some oil, the emulsion of the two making the sand "quick."

Wells. - The wells in this area are all drilled. They range from about 150 to 240 feet in depth, and penetrate the oil sand at 125 to more than 200 feet.

Product.-In their prime the wells produced as high as 15 barrels a day each, but the average was probably never more than 3 to 5 barrels. One group of wells which produced from 6 to 10 barrels a day each when first pumped, soon dropped to a daily average of about 3 barrels, which was held for two years. One of the Wilson wells' (No.. 2), which had an initial flow of only 3 or 4 barrels a day, suddenly rose to a production of 15 barrels a day soon after it started, and kept this up for over a year and a half, although the adjacent wells never averaged over 2 or 3 barrels a day each. It seems likely that this particularly good producer must have penetrated a rich crevice or locally extremely porous place in the oil-bearing bed. A group of wells opposite the Lillis wharf and south of the railroad increased in production when the wells opposite them across the track were abandoned.

The gravity of the oil ranges from $12^{\circ}$ to $15 \frac{1}{2}^{\circ}$ Baumé, the lightest oil coming from the wells at the east end of the field. The average gravity for the entire area is probably about $13^{\circ}$. It is thought that the water which is pumped in varying amounts with the oil has had 
deleterious effect on its gravity, those wells producing the lightest oil pumping the least water. Traces of sludge accompany the oil and water in some of the wells.

Companies.-Among the companies and individuals who are now operating or have operated in this area are the following: Alameda and Santa Barbara Development Company, Doulton \& Wilson, Forester \& Treadwell, W. M. S. Moore, Seaside Oil Company, J. C. Wilson, California Oil Company, Miller \& Williams, Roberson Oil Company, and Packard Oil Company.

\section{BEACH AND WHARF. WELLS.}

Geology and structure.-The formations penetrated by the beach and wharf wells are similar to those found in areas to the north, except that the Pleistocene is lacking and in its place is a veneer of beach sand from 2 to 5 feet in thickness covering the Fernando sandstones, shales, and clays. Treadwell (Southern Pacific Company) well No. 15 encountered gas in hard shale at a depth of about 600 feet, and this is supposed to represent the bottom of the Fernando and the top of the Monterey in this part of the field. The Fernando dips southward over practically the whole region, although near the Treadwell wharf it has a local low northerly dip; at the shore end of the Oxnard and Duquesne wharves the beds assume a low dip preparatory to passing over the Loon Point anticline. From the east end of the field westward the southerly dip in the Fernando is as follows: Eastern Duquesne wharf, $15^{\circ}$; western Duquesne wharf, $20^{\circ}$; Sea Cliff wharves, $21^{\circ}$; Oxnard wharf, $22^{\circ}$; Treadwell (Southern Pacific Company) wharf, $15^{\circ}$ to low north dip; North Star wharf, $10^{\circ}$ to $50^{\circ}$; and Becker wharf, $50^{\circ}$. As shown by the sections (Pls. VII, VIII), there are two or three local crumples in the beds, the one first showing in the Oxnard section and passing' thence northwestward through the Treadwell section and so on into the region north of the North Star and Becker wharves being the most persistent. (See Pl. VIII, p. 38.) Some faulting probably accompanied the folding that produced this wrinkle, especially toward its north end. The Loon Point anticline dies out to the north of the east end of the beach area, so that it apparently exerts little influence on the accumulation of the oil over most of the territory west of the Sunset wells. A small but nevertheless noticeable crumple in the oil sand occurs between Becker wells Nos. 2 and 3 and between North Star wells Nos. 2 and 3.

Several oil sands are met in the wells, the principal one (A in fig. 3 and Pls. VII, $B$, and VIII) being a continuation of the single sand found in the areas to the north. All of these sands, with the exception of the "oil rock" found in the wells at the east end of the area, are typical quartzuse sands ranging from grains the size of a mustard seed up to 
pebbles of considerable size. They are largely "quick" or "heaving' sands, requiring frequent removal from the wells. In fact, many of the wells pump considerable sand with the oil, the separation of the two being accomplished in a "sand box." Sand A ranges in thickness from about 25 to nearly 75 feet, being thinnest near the shore and thickest toward the south end of the wharves. The evidence offered by the wells indicates that the Fernando was laid down under rapidly

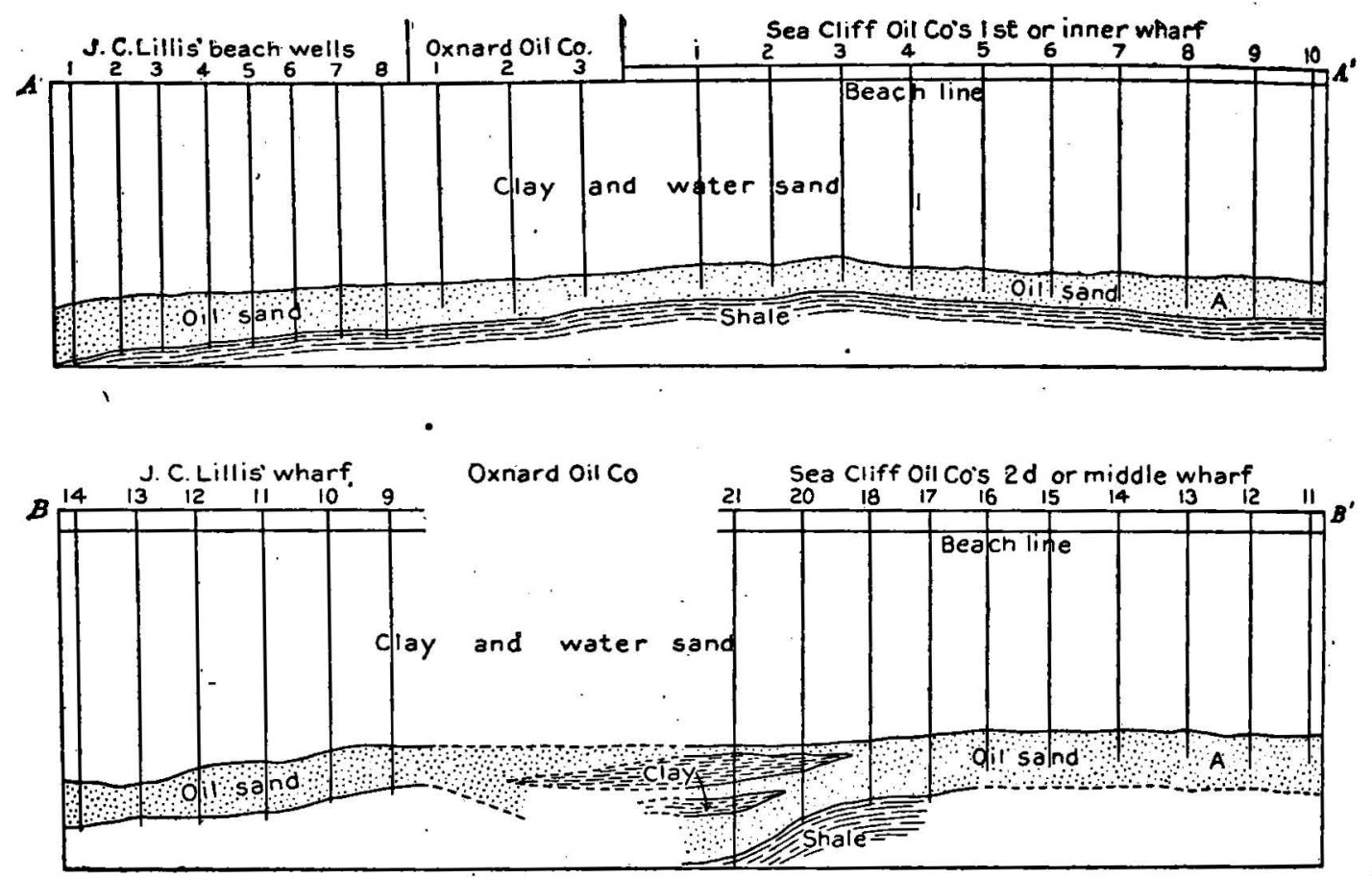

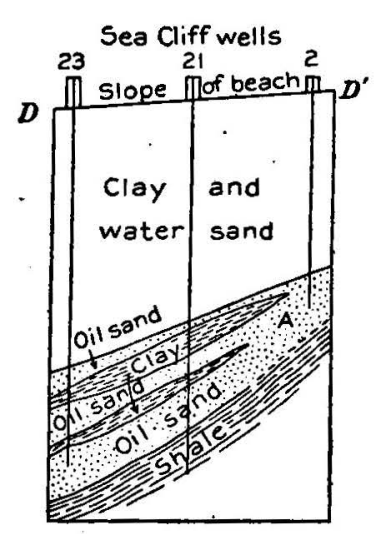

100

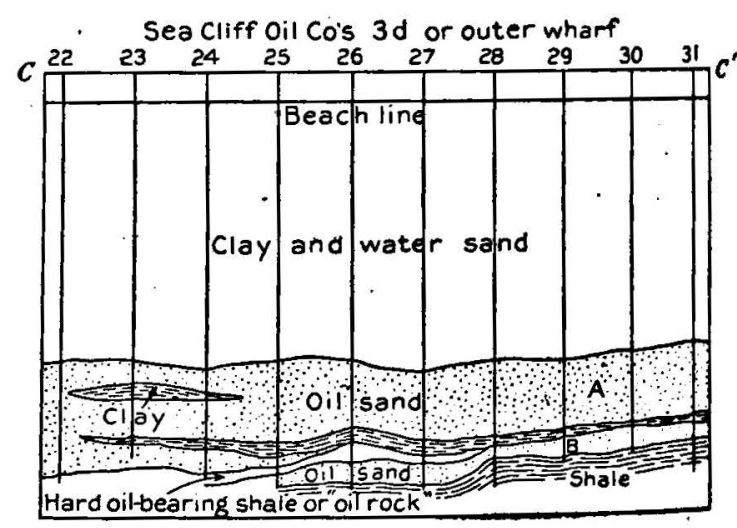

300 feet

Fig. 3-Geologic sections through the Lillis, Oxnard, and Sea Cliff wells. $A-A^{\prime}, B-B^{\prime}$, and $C-C^{\prime}$ shor the relations of the oil sands along the strike; $D-D^{\prime}$, the relations across the strike. A designates principal oil sand. See PI. VI (p. 36) for location of sections. Figures denote number of wells.

changing conditions, which have resulted in great variations in the thickness and composition of the same bed within short distances, these variations being very marked in the oil sands, as well as in the associated layers. (See sections in fig. 3 and Pls. VII and VIII.) The sands contain in many wells included clay lenses and are locally split up by intercalated clays. The variation in the sands is apparent not only in the sections which cut across the strike, but also in those which 
parallel the strike, as is shown in fig. 3. Sand A is overlain throughout this area, as well as throughout other parts of the field, by a persistent tough clay layer which appears to be almost completely impervious to the oil below and the water above it. At the north end of the area (see North Star and Becker sections, Pl. VIII) a productive oil sand is intercalated in the lower part of this layer. To this stratum and to similar less important clays above the other sands the retention of the oil in the porous layers is due, inasmuch as these clays act as barriers to the upward migration of the oil toward the surface from the Monterey shale below the unconformity. Had it not been for the clays nearly all of the oil would have escaped to the surface to form asphalt deposits, such as those at Carpinteria and other places along the coast, where the Monterey shales are petroliferous, but where the conditions are not as favorable for the accumulation of oil as they are at Summerland. Sand $A$ is underlain by a clay stratum which in turn overlies sand $\mathrm{B}$, a productive layer varying from a mere stringer to a bed 25 or 30 feet thick. Still another sand below, separated from B by clay, is struck in some of the wells. The oil sands below A are not found north of the shore-line wells, indicating that they pinch out and should be considered more in the nature of local lenses of sand rather than beds continuous over considerable areas. The "oil rock" previously mentioned occurs below the $B$ sand in the Duquesne and adjacent wells, and consists of hard shale in which is found an oil $1^{\circ}$ or $2^{\circ}$ lighter than that occurring in the true sands. Oil is also derived from crevices in the clay in one of the dug wells at the west end of the field, these crevices conforming in general slope to the dip of the beds.

The following are two typical logs from this area:

Typical log of well on the shore line, Summerland.a

\begin{tabular}{|c|c|c|c|c|c|}
\hline & $\begin{array}{l}\text { Thick- } \\
\text { ness. }\end{array}$ & Depth. & . & $\begin{array}{l}\text { Thick- } \\
\text { ness. }\end{array}$ & Depth. \\
\hline 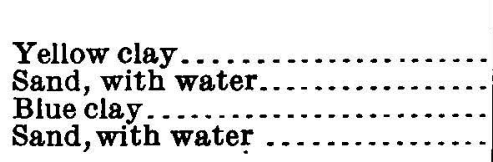 & $\begin{array}{r}\text { Feet. } \\
100 \\
20 \\
30 \\
30\end{array}$ & \begin{tabular}{r|} 
Feet. \\
100 \\
120 \\
150 \\
180
\end{tabular} & 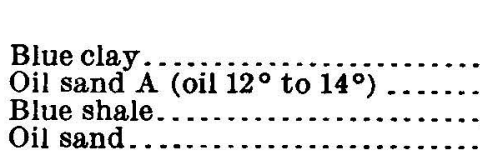 & $\begin{array}{r}\text { Feet. } \\
50 \\
50 \\
20 \\
100\end{array}$ & $\begin{array}{r}\text { Feet. } \\
230 \\
\cdot 280 \\
300 \\
400\end{array}$ \\
\hline
\end{tabular}

a Watts, W. L., Bull. California State Mining Bureau, No. 19, 1900, p. 102.

Log of one of the Duquesne wells, typical of those at east end of wharf area, Summerland.

\begin{tabular}{|c|c|c|c|c|c|}
\hline & $\begin{array}{c}\text { Thick- } \\
\text { ness. }\end{array}$ & Depth. & & $\begin{array}{c}\text { Thick- } \\
\text { ness. }\end{array}$ & Depth. \\
\hline $\begin{array}{l}\text { Alternating clay and water sand. } \\
\text { First oil sand }(\mathrm{A}) \ldots \\
\text { Clay } \ldots \ldots \\
\text { Water sand } \\
\text { Clay } \ldots \ldots\end{array}$ & $\begin{array}{r}\text { Feet. } \\
330 \\
45 \\
6 \\
4 \\
6\end{array}$ & $\begin{array}{r}\text { Feet. } \\
330 \\
375 \\
381 \\
385 \\
391\end{array}$ & $\begin{array}{l}\text { Second oil sand.................. } \\
\text { "Oil rock" (shale with traces of } \\
16^{\circ} \text { to } 170^{\circ} \text { oil) } \ldots \ldots \ldots \ldots \ldots \\
\text { Oil sand (slight amount of oil).... }\end{array}$ & $\begin{array}{r}\text { Feet. } \\
14 \\
48 \\
5\end{array}$ & $\begin{array}{l}\text { Feet. } \\
405 \\
\\
453 \\
458+\end{array}$ \\
\hline
\end{tabular}


Above the persistent clay layer over sand $\mathrm{A}$ is a series of alternating sand and clay beds carrying water. In the region extending from the Becker wharf to the Treadwell (see PI. VII, $B$, and Pl. VIII, section B, p. 38), a 75-foot stratum of sand carrying some oil with the water overlies the clay. The relations of the oil and water in this bed as indicated by the well logs are very interesting, as showing that under certain conditions water and what is apparently an emulsion of water and oil may occupy the same bed, with the water above or up the slope from the oil.

Water is encountered at the base of the oil sand in Oxnard well No. 8, at the south end of the wharf, but does not extend northward or up the slope to No. 7. This occurrence indicates that the water under hydrostatic pressure is following up the oil and will in time probably replace the oil as the latter is pumped from the sands. Water has always been troublesome in the beach and wharf area, but much of the difficulty with it has arisen from faulty manipulation of the wells. There is evidence, however, that in many of the wells the water is following up and replacing the oil. In speaking of the oil and water in one stratum of sand, Mr. Becker informed Mr. Eldridge that he found the oil in the upper half of the bed and the water in the lower half. Just after piercing the stratum and while the gas pressure is maintained, the oil remains distinct from the water, but after the gas pressure is relieved the oil is gradually permeated by the water, with a deterioration of the oil itself, viz, a lowering of the gravity of the oil after a separation of the two components of the emulsion. It is said that no water entered with the oil from sand B for over a year after the wells penetrated it. Sulphur water is encountered in a clay lens in one of the Marine Oil Company's wells and also in the clay between the first and second oil sands in the same wells.

Wells.-With the exception of three dug wells on the beach at the north end of the area, all of the wells are drilled, the casing used ranging in diameter from about $4 \frac{1}{2}$ to 12 inches. "In drilling beneath the water a casing larger than that needed for the drill hole is put down to the floor of the ocean and forced into the bed rock until the ocean water is securely shut out of the drill hole. This is called a conductor, and the casing of the well is put down inside of the conductor." $a$ The main oil sand (A) is penetrated in the wells st depths of 125 to about 325 feet. The range of depths for the different wharves is as follows: Eastern Duquesne, 160 to 315 feet; western Duquesne, 200 to 325 feet; Sea Cliff, 125 to 200 feet; Oxnard, 125 to 290 feet; Treadwell (Southern Pacific Company), 200 to 250 feet; North Star, 5 to 350 feet; Becker, 5 to 310 feet. 
Product.-The individual production of the drilled wells varies from a fraction of a barrel to that of one of the Duquesne wells, which is said to have had an initial production of 100 barrels a day. It is claimed that this well continued this production, which is phenomenal for this field, for six months, but finally fell off to an average of 3 or 4 barrels a day. The general average for the wharf wells at the present time is between 1 and 2 barrels a day each; this is probably less than one-half the average for the field when it was in its prime.

Of the dug wells, the best producer was a 60 -foot hole in the bottom of which was sunk 17 feet of $9 \frac{5}{8}$-inch casing. This is said to have been capable of producing 100 barrels a day at one time. The other dug wells yielded from 3 to 10 barrels a day each.

The best production has usually been in the most-disturbed strata. The Williams wells, for instance, in the steeply dipping beds at the north end of the field, have been, with only a few exceptions, the best producers. Oxnard No. 6, the best producer of the group, is located on a local flexure (see PI. VIII, section C, p. 38), and so there are other cases. No. 12 of the eastern Duquesne wharf, which is said to have been a 100-barrel well, probably tapped a locally rich place in one of the lower sands. The initial production of each well is ordinarily about twice its production after one year and three or four times its production after two years. The subjoined record of one of the Duquesne wells illustrates the rate of decline in production:

Decrease of production in one of the Duquesne wells, Summerland.

\begin{tabular}{|c|c|}
\hline Barrels a day. & Barrels a day. \\
\hline ay, 1898 (initial flow) $\ldots \ldots \ldots \ldots \ldots 6$ & February 16, 1900 \\
\hline Ine $8,1899 \ldots \ldots \ldots \ldots \ldots \ldots \ldots$ & February $22,1900 \ldots \ldots \ldots \ldots \ldots \ldots, 21$ \\
\hline 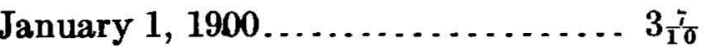 & August $25,1900, \ldots, \ldots .$. \\
\hline
\end{tabular}

The wells down the dip usually give a slightly better yield than those higher up in the same stratum, although in the case of the wharf wells this may be due in part to a thickening of the strata. The good yield of some of the wells farthest south on the wharves is also explained by the fact that they tap the second and third oil sands, which have proved to be in places exceptionally productive. In the eastern Duquesne wells, which penetrate two sands, no well pumps from both strata, but each stratum is pumped in alternating wells, the lower stratum being the more productive. In the western Duquesne wells an average of $4 \frac{1}{4}$ barrels a day was yielded by each of the 14 wells along the beach which tapped the upper sand, while the six wharf wells, which obtained their petroleum from the lower stratum, produced an average of $6 \frac{2}{3}$ barrels per day.

The oil obtained from the wharf and beach wells ranges in color from black to olive-brown, the latter being the lighter, and in gravity from $12^{\circ}$ to $18^{\circ}$, with an average of about $15^{\circ}$ Baumé. The heaviest oil comes from the main oil sand (A) in the beach wells throughout

1783-Bull. 321-07-4 
the central part of the area; the $14^{\circ}$ to $15^{\circ}$ oil from the same sand in the great majority of the wharf wells; the $16^{\circ}$ oil largely from the second or B sand; the $17^{\circ}$ to $17 \frac{1}{2}^{\circ}$ oil from the "oil rock" below the main oil sand in the eastern part of the field; and the oil, which is said to have tested $18^{\circ}$ from Williams No. 2 well, in the highly tilted beds at the extreme west end of the field. Certain wells on the beach and edge of the bluff, between the Becker and Treadwell wharves, are said to have been abandoned because the sand yielded liquid asphaltum too heavy to pump. Similar asphaltum is also reported in sand $A$ at the bottom of North Star No. 8, although the oil in the same stratum less than 100 feet farther north, up the dip, was reported as of $15^{\circ}$ gravity.

It is said that in the Sea Cliff wells the oil in the upper or A sand is lighter along the beach than southward and seaward down the dip. Exactly the opposite condition is reported in the steeply dipping beds in the North Star section, where (with the exception of the very heavy oil in the bottom of No. 8) the lightest oil is that from the well farthest out on the wharf. This occurrence of the lightest oil in the beds farthest down the dip is by far the most common in the Californis fields so far examined by the writer. The conditions at the Sea Cliff wells may be explained on the assumption that the oil reached sand $A$ through crevices along the axis of the Loon Point anticline (see Pl. VI, p. 36) and spread southward down the dip of the beds, losing in gravity as it migrated.

Water, sludge, and gas accompany the oil in most of the wells of the area. The product ranges from an initial yield of oil containing practically no water to an emulsion containing 98 or 99 per cent of water. The average emulsion coming from those wells which have received fair attention contained from 18 to 22 per cent of water at the time of the writer's visit (1906). Many neglected wells produced practically all water, with only occasional traces or blebs of oil. It is said that well No. 14 on the eastern Duquesne wharf pumped practically pure oil for the first six months, after which water gradually increased up to 22 per cent, but that the net production of oil at the time it contained 22 per cent of water was greater than when it pumped oil alone. The greater fluidity of the emulsion in this case seemed to more than compensate in increased production for the loss of quality of the oil.

- Sludge is pumped with the oil, its amount ranging from a trace up to 45 per cent.

Companies.-The companies which have at one time or another operated the beach and wharf wells, named in the order of the wells from east to west, are the Duquesne (Keith and Williams wharres), 
Southern Pacific, Sea Cliff, Oxnard, Lillis, Sunset, W. M. S. Moore, Treadwell (Southern Pacific Company), Marine, Knapp, McCall, Santa Barbara Oil and Mining, North Star, Becker, and Williams.

\section{GAS WELLS IN THE SUMMERLAND FIELD.}

General statement.-In addition to the gas which accompanies the oil in practically all the wells in the Summerland field there are more than a dozen wells which have produced nothing but gas. Though the flow of these wells was more or less powerful at first, they were quickly exhausted and all are now abandoned.

Geology and structure.-Some of the wells obtained their gas from the sands near the base of the Fernando formation, while at least three are believed to start down in the Monterey shale and penetrate gas accumulations in this formation. In both cases the beds dip to the south, the Fernando lying at a low angle unconformably over the Monterey, which is believed to be steeply tilted. The strata that yielded the gas in the Fernando are believed to be practically at the same horizon as sand A, which produces the oil in the wells a little farther south. In one of the Cone wells, in the eastern part of the town, the gas occurs at 600 feet below the surface, while oil is obtained 25 feet farther down. This occurrence, together with the general position of the gas wells at the top of the Summerland monocline, is interesting in substantiating the theory that wherever oil and gas occur separately in the same bed the gas will always be found at the top. In fact, the Summerland field as a whole furnishes a good illustration of the conditions postulated by the anticlinal theory, which states that where water, oil, and gas are found separately in the same bed the water will be found lowest, the oil next, and the gas at the top. The A. C. Doane well, at the southwest corner of Wallace avenue and Evans street, is typical of those which obtain gas from the Fernando oil-bearing horizon. It passes through reddish clay to 70 feet and gas sand to 83 feet, the clay forming the impervious cap.

In all the wells in the Monterey the gas' was found under a hard limy shell layer, which had apparently been impervious to the gas. Traces of oil occur in the sandy layers in these wells below the level of the gas. The following log of one of the Darling Brothers' wells in the northwestern part of Summerland is typical of the gas wells in the Monterey shale. 
Log of Darling Brothers' gas well on lot 32, block 25, Summerland.

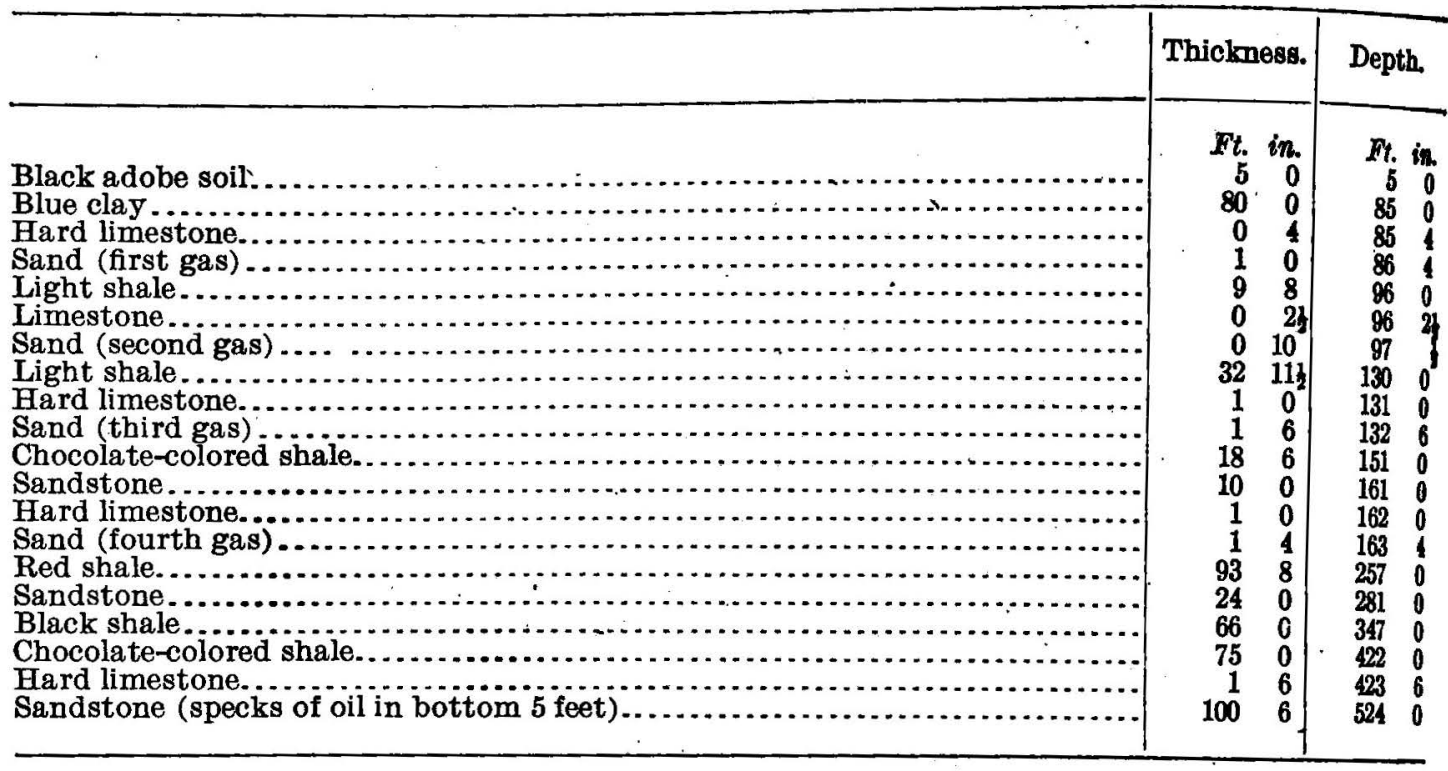

Production of the wells.-The gas wells range in diameter from 2t to $4 \frac{1}{2}$ inches, the shallowest usually being the smallest. The pressure of the gas was strong at first, but gradually fell off. One well, 104 feet deep, is said to have thrown mud and dirt 40 feet in the air when the gas sand was first penetrated. One of the Darling wells started in 1891 with a pressure of 8 pounds to the square inch and furnished gas to 17 families. In 1895 the pressure had fallen to 1 pound to the square inch. The three Cone wells supplied 20 families at first, but in four years fell off until they yielded barely enough gas for 3 families. The Cone wells had about the most enduring supply of all in the field.

One of the most interesting phenomena in relation to the gas supply in the gas wells and oil wells is the influence of the weather of denseness of the atmosphere on the flow. In speaking of the Darting Brothers' wells, Watts says: ${ }^{a}$ "It is stated that during a north wind these wells yield a strong flow of gas, but when the wind ceases the gas ceases to flow and a current of air is drawn down the well for several hours. In one instance, the latter phenomenon was noticed to continue for two days before inflammable gas again flowed from the well." ' It would seem that such phenomena would result in a dargerous mixture of air and gas, but so far as the writer is aware no serious accidents accompanied the use of the gas for domestic purposes. In the Doane wells a heavy north wind caused the cessation of the gas flow entirely, this action being exactly contrary to the phenomena noted in the Darling wells. The gas in some of the ol wells on the beach was said to have increased in volume and the wells to have pumped better at high tide and in stormy weather. It 
was also noted that when the Santa Barbara Oil and Mining Company's well No. 6, on the edge of the bluff, was pumped the gas flow ceased in No. 11, which was located 30 feet farther north.

\section{SUMMARY OF CONCLUSIONS CONCERNING THE OIL.}

The oil in the Summerland field originates by a slow process of distillation from the diatoms and other organisms in the Monterey (middle Miocene) shale, which is abundantly developed in the region. After its formation quantities of the oil migrate upward, largely through joint cracks, under gas or hydrostatic pressure, and accumulate in the Fernando formation in porous sandstones under relatively impervious clay layers. The reason that the oil does not continue its upward migration through the Fernando to the surface is because the plastic condition of certain clay beds in that formation precludes the production of cracks that could act as channels for the oil. In certain places, however, notably at the north end of the field, the Fernando beds have been so steeply tilted that some of the oil has migrated along the sandy layers and accumulated, with a loss of volatile constituents, in the unconformably overlying Pleistocene. sands and gravels.

The migration, accumulation, and characteristics of the oil are largely influenced by the composition and structure of the containing formation. The composition of the Monterey shale and certain portions of the shale at the base of the Fernando is such that the oil can migrate through them readily only when they are in a more or less fractured condition. As a result of this characteristic the largest accumulations of oil in the Monterey occur in the more gently folded beds, such as along the anticline east of Carpinteria, while the important deposits in the Fernando lie over or near the more intensely fractured portions of the Monterey.

The migration of the oil and its accumulation in the porous members of the Fernando are governed largely by the structure. The transference and collection appear to vary with the degree of dip, the greatest accumulations, other things being equal, occurring in the most highly tilted strata. This is illustrated by the greatest producers of this region, most of which penetrate the steeply dipping beds at the north end of the field.

The oil deteriorates with upward migration both in the Monterey shale and in the Fernando formation. This deterioration in the Monterey is exemplified by the Rincon well, which yields oil of $20^{\circ}$ gravity, whereas heavier oil and even asphaltum is obtained at the neighboring Monterey outcrops. In the Fernando formation the wells on the western Duquesne wharf offer a striking illustration, the gravity of the oil here being $17^{\circ}$ to $17 \frac{1}{2}^{\circ}$ in the lowest oil stratum, $16^{\circ}$ in the next, and $14^{\circ}$ in the uppermost. The Oxnard and several 
other groups also present good examples, the lower sand in the Oxnard wells yielding $15 \frac{1}{4}^{\circ}$ oil, while that in the upper sand is $14^{\circ}$. In its migration upward through sand $A$ in the Becker wells the oil declines in gravity from $15^{\circ}$ to $14^{\circ}$ and finally to $13^{\circ}$ within a horizontal distance of less than 150 feet up a $45^{\circ}$ slope. (See Pl. VIII, section A, p. 38.) An apparent anomaly occurs in this same group of wells, heavy oil of $13^{\circ}$ or less occurring down the dip below and in the same sand with the $15^{\circ}$ oil. Another apparent anomaly is shown in the Oxnard section (Pl. VIII, section C), in the occurrence of $151^{\circ}$ oil in the Miller wells at a much higher point than the $14^{\circ}$ oil in the wells out on the wharf. This occurrence may be explained on the hypothesis that the Miller oil migrated upward through the joint cracks in the heart of the Loon Point anticline rather than into sand $A$ at points on its flank and thence up along the sand stratum. An alternative but less likely explanation of such phenomena is that for some reason the oil loses in gravity as it passes upward in the steeply dipping beds, while in beds of low dip the lightest oil is found at the top. Other things being equal, it is generally true that lighter oil comes from the finer sediments.

In any closed, tilted reservoir, such, for instance, as sand $A$, the water, oil, and gas separate according to their specific gravities, the water occurring down the slope, the oil above this, and the gas in the uppermost parts of the bed. Within the reservoirs, especially in those portions which are less steeply inclined, the oil and water may occupy adjacent zones parallel to the bedding planes, with no parting of clay or other impervious matter between. Neither the oil nor the water in such cases is pure, but each contains greater of less amounts of the other. It is because of the accumulation of the oil in the top of the oil sand in the manner described above that many of the wells penetrate only a portion of the stratum. (See fig. 3, sections $A-A^{\prime}$ and $B-B^{\prime}$, p. 44.)

The association of oil with water has a deleterious effect on the gravity of the oil. For example, oil pumped from a certain sand in the Summerland field had a constant gravity until water began to enter the well, when it was noticed that the gravity of the oil after separation from the emulsion was less than it was before the water came in.

WELLS AT OTHER LOCALITIES IN THE SUMMERLAND DISTRICT.

WELLS NEAR LOON POINT.

Several prospect wells have been put down in the Fernando forms tion near Loon Point, about a mile east of the Summerland field, but none were successful, although oil sands with traces of oil were penetrated in most of them. It is the opinion of the writer that the 
paucity of petroleum is due to the position of the Fernando beds, which are believed to overlie here the nonbituminous Vaqueros rather than the petroliferous Monterey as they do farther north in the Summerland field. The position of the Loon Point wells relative to the anticline is apparently advantageous and the only reason that can be assigned for their nonproductiveness is that stated above.

Some of the wells attained a depth of 500 feet, but none were ever operated. The Fischer dug well, one-fourth mile north of the point, was 124 feet deep and reported small quantities of heavy dark-green oil. The following log of the Nott \& Webber well, put down from the end of a 310-foot wharf one-half mile west of Loon Point, is characteristic of the wells in this vicinity:

Log of Nott \& Webber well, one-half mile west of Loon Point.

\begin{tabular}{|c|c|c|}
\hline & $\begin{array}{l}\text { Thick- } \\
\text { ness. }\end{array}$ & Depth. \\
\hline $\begin{array}{l}\text { Sandstone, blue clay, and occasional 2-foot to } 3 \text {-foot sand and gravel beds with water. } \\
\text { Brown and chocolate-colored shale, with stratum of water tapped at } 460 \text { feet flowing }\end{array}$ & $\begin{array}{r}\text { Reet. } \\
380\end{array}$ & $\begin{array}{l}\text { Feet. } \\
380\end{array}$ \\
\hline $\begin{array}{l}\text { over collar } \\
\text { Clay, with streaks of oil sand carrying oil. }\end{array}$ & $\begin{array}{r}150 \\
30\end{array}$ & $\begin{array}{l}530 \\
560\end{array}$ \\
\hline
\end{tabular}

Water in this well would stop flowing when the well next to the southernmost on the Duquesne wharf, three-eighths of a mile west of Nott \& Webber's wharf, was pumped. When the Duquesne well stopped pumping Nott \& Webber's well would flow again, but water always reached the top of the casing in the Nott \& Webber well, even when the Duquesne well was pumped. It was calculated that the Nott \& Webber well was in strata 150 feet deeper than that of the Duquesne, which contained the water.

\section{WELLS NEAR CARPINTERIA AND RINCON CREEK.}

Several wells, at least one attaining a depth of over 3,000 feet, have been sunk on the lowlands in the region near Carpinteria and the mouth of Rincon Creek, 5 to 8 miles east of Summerland. Traces of oil were found in all of them, but none so far have been highly successful. In all the wells the strata penetrated beneath the superficial Pleistocene deposits have been the Monterey (middle Miocene) bituminous shale, which lies in steeply dipping positions throughout this coastal belt.

The most important and deepest well is that of the Columbia Oil and Asphalt Company, located on the north side of the railroad onehalf mile east of the asphalt mine at Carpinteria. It is put down in line with the axis of a sharp anticline which extends into the ocean about a mile east of the mouth of Carpinteria Creek, near the edge of the area shown on the map. No definite information concerning the well was obtainable at the time of the writer's visit (October, 
1906), but the following notes were gleaned from various sources: The well penetrates shale throughout the greater part of its depth, is about 3,000 feet deep, and encounters artesian water with a head of 12 feet at 100 to 150 feet, asphaltum at 1,200 to 1,400 feet, and oil in sandy layers in the lower 100 feet. The oil in the sump is black and heavy, although it is said by the operators that oil of $37^{\circ}$ gravity was struck near the bottom. The oil is accompanied by a strong gas pressure. Gas was also encountered with the asphaltum between 1,200 and 1,400 feet, forcing the asphaltum up in the hole for a distance of 180 feet when first struck. Only a small amount of oil was on the sump, indicating that the production of the well is probably not large.

Several years ago a well was sunk in the shale at the edge of the bluff about one-fourth mile east of the asphalt mine. Heavy oil was struck, but it was too viscous for pumping, and the well was abandoned. The casing of this hole still protrudes from the ground, and a heavy ail accompanied by considerable gas is slowly escaping from it. It is said that a second well was sunk a short distance farther northeast, but that no oil of consequence waś encountered in it. As the first well is near the northern limit of a highly disturbed zone, it seems very likely that the reason no oil was encountered in the second well was because it penetrated beds which were so little fractured that the oil had no channels of migration through them.

In 1894 a 4 by 6 foot well was dug to a depth of 354 feet by P.C. Higgins, on the seashore one-half mile west of the asphalt mine. Purplish bituminous shale, with casts of the fossil Pecten peckhami Gabb, was the only formation penetrated, and no oil was encountered.

A 400-foot well was drilled by J. Heath on the Hill ranch just north of the mouth of Rincon Creek, oil being struck in small quantities from 150 feet downward.

Watts ${ }^{a}$ gives the following reference to prospect wells of the Arctic Oil Company east of Carpinteria:

Well No. 1, 7 miles south of Rincon Creek, 1,825 feet deep; formation, red sandstone; no oil. Well No. 2, 50 feet distant from well No. 1, 2,100 feet deep; formation, red sandstone; no oil. Well No. 3, on Southern Pacific Railroad 11 miles east of Carpinteria; conglomerate and sandy shale to 700 feet; shale and sandstone to 1,200 feet; liquid asphaltum; well abandoned.

The conglomerate here mentioned is probably the Pleistocene gravel and sand, which overlies the Monterey shale to a depth of over a hundred feet in the region northeast of Carpinteria.

At the time of the writer's visit to Carpinteria (October, 1906) it was reported that a well was being sunk at Shepards, 2 miles northeast of the mouth of Rincon Creek; but no data concerning its depth or the formation penetrated were obtainable. 
WELLS IN THE MOUNTAINS NORTHEAST OF SUMMERLAND.

Several wells have at different times been put down in the Topatopa formation (Eocene) in the mountains east and northeast of Summerland. The wells have all been located near oil springs or seepages, and have without exception yielded traces and some of them commercial quantities of oil. Light yields and lack of proper transportation and market facilities have discouraged development, and at the present time none of the wells are being operated. Among the wells are those of the Santa Barbara Oil Company in Oil Canyon, the Occidental Mining and Petroleum Company in Toro Canyon, the Santa Monica Oil Company in Santa Monica Canyon, and the Pinal Oil Company at the mouth of Arroyo Parida. These will be briefly described.

Two wells were drilled by the Santa Barbara Oil Company in Oil Canyon about $3 \frac{3}{4}$ miles northeast of Summerland. The rocks here exposed are the overturned upper Topatopa shale, which dips steeply at angles ranging from $60^{\circ} \mathrm{N}$. to vertical; oil springs occur in them in the immediate neighborhood of the wells. The wells start down in the shale, but may penetrate to the stratigraphically higher but actually lower upper-sandstone belt. The wells are between 500 and 600 feet deep, and yielded small quantities of oil and much gas.

Seven wells and one tunnel have been sunk by the Occidental Mining and Petroleum Company in Toro Canyon about $3 \frac{1}{4}$ miles northeast of Summerland and three-fourths of a mile west of those of the Santa Barbara Oil Company just described. The formation at the Occidental wells is the same as that in Oil Canyon, and the wells doubtless derive their oil from the same zone. The wells range in depth from 200 to 1,100 feet. Four of them were classed as productive and three dry, although the latter contained traces of oil. No. 1 is said to have produced a total of 5,000-barrels and No. 5 was rated as a 5-barrel well; the average for the productive wells was about 2 to 3 barrels a day each. In August, 1895, only one well was pumping, and the oil from this was largely mixed with water. The oil is black and of $17^{\circ}$ Baumé gravity when it first comes from the wells, but on standing for a little while drops to $14^{\circ}$. The tunnel is 511 feet long and runs in a N. $10^{\circ} \mathrm{E}$. direction into the mountains. It penetrates sandstone composed of quartz, feldspar, and green and reddish minerals, interbedded with the greenish shale. It yielded little oil but much water, and the latter is now being used in Summerland. An analysis of this water is given on page 24 .

The well of the Santa Monica Oil Company is located 2 miles north bf Carpinteria, near the mouth of Santa Monica Canyon. It starts down in the lowest Sespe sandstone, which here dips $60^{\circ} \mathrm{S} .10^{\circ} \mathrm{W}$., and penetrates the alternating sandstone and shale of the uppermost 
Topatopa. A yield of 8 barrels a day of $18^{\circ}$ amber-colored oil accompanied by strong gas pressure was encountered at 400 feet. At 700 feet a strong flow of sulphur water "drowned out" the oil and the well is now abandoned.

The Pinal Oil Company is putting down a well at the mouth of Arroyo Parida Canyon, about $3 \frac{1}{4}$ miles east of Summerland. It penetrates the lowest Sespe sandstone and the uppermost Topatopa alternating sandstones and shales, which here dip $60^{\circ} \mathrm{S}$. It is thought that the well will reach the oil in sands under a certain shell at a depth of something more than 1,000 feet.

\section{WELLS WEST OF SUMMERLAND.}

Several wells have been drilled in the region west of Summerland, but few data concerning them are available. The following references by Watts ${ }^{a}$ are self-explanatory:

Illinois Oil and Asphalt Company.-Has a well on the seashore at Montecito. Formar tion, yellow clay and sand to 200 feet; blue clay and quicksand, with gas, to 260 feet; blue shale to 280 feet. Unfinished June, 1900. ${ }^{\natural}$

Santa Barbara and Naples Oil and Land Company. - The territory operated by this company is near the seashore about 15 miles west of Santa Barbara. In June, 1900, this company was drilling a well, the formation penetrated being principally shale to \& depth of 450 feet, with some showing of gas and oil.

\section{CONCLUSIONS CONCERNING FUTURE DEVELOPMENT.}

General statement.-It must be continually borne in mind that absolute determination of the possibilities of occurrence or nonoccurrence of oil in any one locality, by work on the surface, even when augmented by a study of the known underground conditions in developed territory, is not possible. The best that can be done is to calculate the degree of probability on the basis of a summation of indications and structural conditions. The following conclusions concerning the prospects of the Summerland district are offered simply as the personal opinion of the writer after a study of this district.

Summerland field proper.-As regards the region immediately about Summerland, it is quite evident that the limits of the productive territory for wells of moderate depth, say up to 600 feet, have been pretty well outlined. The question for this territory seems to be more one of transportation facilities, markets, and cooperation among the operators than of unknown possibilities of development. There is certainly considerable territory between the Becker and Duquesne wharres, not to mention other undrilled territory in the northern part of the field, that should yield good returns for the cost and care of wells if the price of oil was what it was a few years ago. Until the price rises of

a Bull. California State Mining Bureau No. 19, 1900, p. 105.

6 As this well was pot being operated in October, 1906, it is assumed that it was a tallure.-B.A. 
until cheaper transportation rates are obtained, however, it seems useless to carry on further development.

The conditions of structure do not appear to favor the probability of striking remunerative deposits of oil by deep drilling. It is true that oil would probably be encountered in wells 2,000 or more feet in depth put down almost anywhere over the territory underlain by the Monterey shale, but the steep dips and close texture of the shale apparently preclude the accumulation of such great deposits of oil as are found in fields where the rocks are less steeply inclined and more porous.

Region near Carpinteria.-The last paragraph is as applicable to the region about Carpinteria and to the east as far as the contorted condition of the shale extends as it is to that territory about Summerland which is underlain by the Monterey. More or less oil is inclosed in the shale and in local interbedded sandstones, but it does not appear likely that heavy producers will ever be encountered in a region of such distortion and fracturing aş is prevalent in the Monterey shale all along this part of the coast, although in certain facies of the shale fracturing seems to be essential to the migration of the oil within or through it.

Region west of Montecito.-It is thought that wells sunk deep enough to penetrate the basal beds of the Fernando formation in the region of the Montecito anticline (see PI. I, p. 18), which extends indefinitely west-northwestward from the coast 1 mile west of Montecito Landing, will strike deposits of oil of about the same quality as the best of that encountered at Summerland.

Region of the Topatopa formation (Eocene) northeast of Summerland.- In the light of the development which has already taken place in Toro, Oil, Santa Monica, and Arroyo Parida canyons it seems almost certain that light producers (averaging from 2 to 6 or 8 barrels a day of $14^{\circ}$ to $18^{\circ}$ oil), 1,000 feet or less in depth, could be put down at many places along the contact between the upper Topatopa shale and sandstone zones or the contact between the Topatopa and Sespe formations in the region northeast of Summerland. The oil-bearing strata in both of these belts are apparently confined to the upper part of the Topatopa, and to obtain productive wells is simply a question of locating places where the structure appears most advantageous for the accumulation of the petroleum. The region near the Arroyo Parida fault, toward the east end of the area covered by the map, appears promising, although the wells here, especially on the north side of the fault, would have to go much deeper to strike the oil zone than they do at the tested localities. 
PHYSICAL AND CHEMUCAL PROPERTIES OF THE OIL.

PHYSICAL PROPERTIES.

COLOR.

Nearly all of the oil in the Summerland field is dark brown or black. The exceptions to this are the olive-brown oil from some of the Becker and Potomae wells, at the north end of the field, and a heavy dark green oil from the Fischer dug well, near Loon Point. The oil from the wells penetrating the Monterey shale (middle Miocene), in the vicinity of Carpinteria and farther east is black, as is also that from the Occidental wells sunk in the Topatopa formation (Eocene) in Toro Canyon. An amber-colored petroleum is reported from the Santa Monica Oil Company's well in the Topatopa sandstone north of Carpinteria.

\section{GRA VITY,}

The gravity of the oil from the Summerland field ranges from $9^{\circ}$ to $18^{\circ}$ Baumé, the average being between $14^{\circ}$ and $15^{\circ}$. The Summerland oil and that from certain portions of the Los Angeles district are the heaviest of the California oils. The oil from the Monterey shale in the region about Carpinteria and Rincon ranges from liquid asphalt (gravity, about $9^{\circ}$ Baumé) to the $20^{\circ}$ petroleum from the Rincon well. It is claimed that oil of $37^{\circ}$ gravity is found in the Columbia Oil and Asphalt Company's well at Carpinteria, but none of this light oil was seen by the writer. The gravity of the oil from the Occidental wells (in the Topatopa formation) is said to be $17^{\circ}$ when it first comes from the wells, but to fall soon to $14^{\circ}$ on exposure to the air. The same formation yields $18^{\circ}$ oil in the Santa Monica well north of Carpinteria.

The lightest oil in the Summerland field is found in the main sand (A), in the beds of steepest dip at the north end of the field; in proximity to the local anticline or fault in the Potomac wells, also at the north end; in the Miller and Williams wells near the axis of the Loon - Point anticline, at the east end; and in the second and third sands in the region of the Duquesne wharves. The heaviest oil comes from some of the beach and bluff wells between the North Star and Treadwell wharves. In general, the oil in any bed improves in quality down the dip, although in the Sea Cliff wells the opposite is said to be true. Water in the wells south of the railroad is believed to account for the lower gravity of the oil from this area as compared to that from the almost water-free oil sands north of the track.

The following table gives the details of the gravity of the oil in the different parts of the Summerland field: 
Gravity of the oil from different parts of the Summerland field.

North of railroad track

Average. $13-14$

Between railroad and beach.............................. 9-15

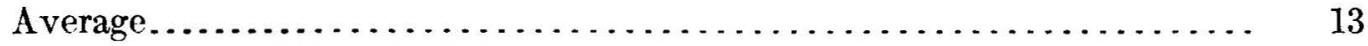

Santa Barbara Oil and Mining Company's wells................ 9-13

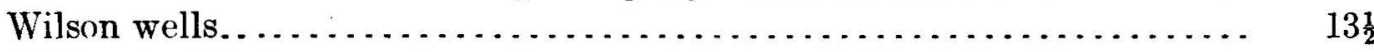

California Oil Company's wells ............................ 12-13

Miller and Williams wells (extreme east end) . . . . . . . . . . . . . $15 \frac{1}{2}$

Beach and wharf wells ................................. 12-18

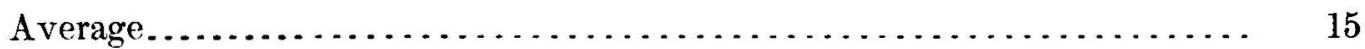

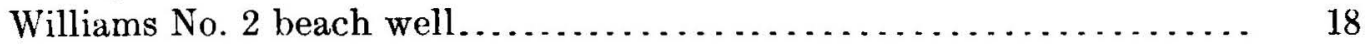

Becker wells...................................... 16-17

North Star wells...................................... 13-15

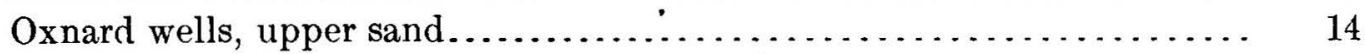

Oxnard wells, lower sand .................................. $15 \frac{1}{4}$

Sea Cliff wells, upper sand, beach......................... 14

Sea Cliff wells, upper sand, wharf . . . . . . . . . . . . . . . . . . 13

Western Duquesne wharf wells, upper sand . . . . . . . . . . . . . . . 14

Western Duquesne wharf wells, middle sand.................... 16

Western Duquesne wharf wells, lower sand "rock" $\ldots \ldots \ldots \ldots \ldots \ldots \ldots \ldots .17 \frac{1}{2}$

\section{VISCOSITY.}

The relative viscosity of the Summerland oils as compared with that of oils from other typical California fields is given in the table of chemical analyses on page 62 .

\section{CHEMICAL PROPERTIES.}

\section{GENERAL STATEMENT.}

For data concerning the chemical properties of the Summerland oil, the writer is indebted entirely to persons outside of the Geological Survey, as up to the present time this Bureau has undertaken no detailed chemical investigations of petroleums. The following, among others, have contributed to the present knowledge of the California petroleums, and to them the writer wishes to acknowledge his indebtedness for the analyses contained in the succeeding pages: Messrs. W. L. Watts, ${ }^{a}$ S. F. Peckham, ${ }^{b}$ Charles F. Mabery, ${ }^{c}$ Clifford Richardson, ${ }^{d}$ Paul W. Prutzman, ${ }^{e}$ H. N. Cooper, ${ }^{f}$ and Edmond O’Neill.g

\footnotetext{
a Bull. California State Mining Bureau No. 11, 1897, pp. 67-69; No. 19, 1900, p. 203

$\checkmark$ See Bull. U. S. Geol. Survey No. 309, 1907, p. 201, for complete list of this writer's papers relating to California petroleum.

c Proc. Am. Acad. Arts and Sci., vol. 36, 1901, pp. 255-283; vol. 40, 1904, pp. 340-346.

d Jour. Franklin Inst., vol. 162, 1906, pp. 57-70, 81-128.

e Bull. California State Mining Bureau No. 32, 1904, pp. 184, 194, 198, 224, etc.

$f$ Bull. California State Mining Bureau No. 31, 1904; No. 32, 1904, opp. p. 230.

$g$ Jour. Am. Chem. Soc., vol. 25, 1903, pp. 707-709.
} 
The most prominent characteristics of the Summerland oil are its low gravity $\left(12^{\circ}\right.$ to $16^{\circ}$ Baumé), its high percentage of asphalt (85.5 per cent, ${ }^{a}$ the highest of all the California oils), its relatively high percentage of nitrogen $\left(1.25\right.$ per $\left.\operatorname{cent}^{b}\right)$, and its moderately low sulphur content $\left(0.84\right.$ per $\left.\operatorname{cent}^{b}\right)$.

\section{RICHARDSON'S PAPER.}

The most comprehensive yet condensed discussion of the chemical properties of the Summerland oil is that by Clifford Richardson in his "Petroleum of North America." c That part of his paper which relates to the Summerland oil is here given in its entirety, as introductory to the tables of analyses which follow. Richardson says:

A specimen of the dense Summerland oil collected by the writer and distilled in vacuo at a pressure of $26 \mathrm{~mm}$. gave 55 per cent of distillate, which was collected in 15 fractions, having the following specific gravity at $20^{\circ}$ :

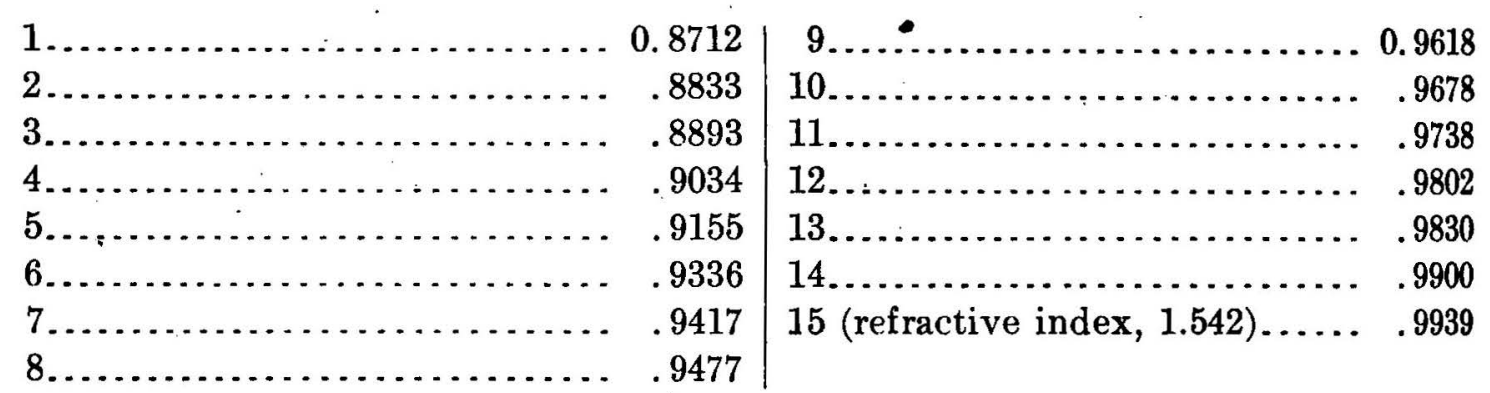

Residue (45 per cent), a hard asphalt. Penetration, 66.

The highest boiling fraction has a density very nearly that of water and a refractive index of 1.542. The residue consisted of a hard residual pitch. On redistilling the first fraction at the same pressure, distillates began to come over at $105^{\circ}$, having a specific gravity of $0.8460,35.5^{\circ} \mathrm{B}$, and a refractive index of 1.460. Paraffin scale could not be separated from any of the fractions on exposing them to an extremely low temperature.

Mabery $d$ has examined this oil in considerable detail. He found that a sample which he obtained, having a specific gravity of $0.9845,12.2^{\circ} \mathrm{B}$, , had the following ultimate composition:

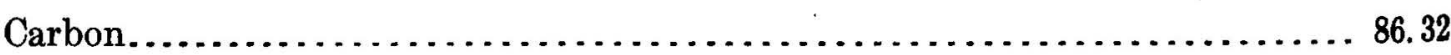

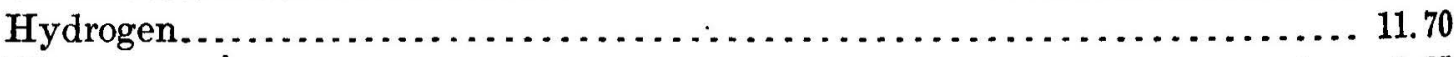

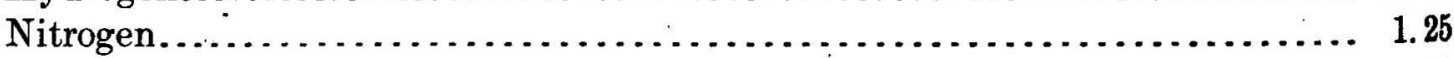

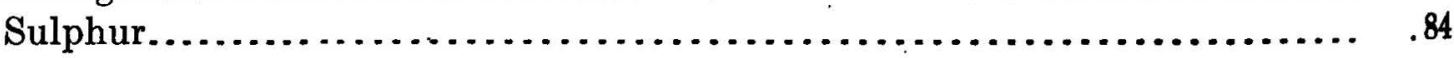

100.11

His distillates were of a character similar to those found by the writer. He continued his fractionation until heaps were obtained at certain temperatures. After purification with sulphuric acid and caustic soda he examined the saturated hydrocarbons thus obtained with the following results:

$a$ Ṗrutzman, P. W., Bull. California State Mining Bureau No. 32, 1904, p. 184

$b$ Mabery, C. F., Proc. Am. Acad. Arts and Sci., vol. 40, 1904, p. 341.

c Jour. Franklin Inst., vol. 162, 1906, pp. 57-70, 81-128.

d Proc. Am. Acad. Arts and Sci., vol. 40, 1904, p. 340. 
Hydrocarbons separated from Santa Barbara (Cal.) petroleum.

\begin{tabular}{l} 
Symbol. \\
\hline
\end{tabular}

The most volatile of these fractions belong to the $\mathrm{C}_{\mathrm{n}} \mathrm{H}_{2 \mathrm{n}_{2} 2}$ series. With the third the series becomes $\mathrm{C}_{n} \mathrm{H}_{2 n_{-}}$, and with the sixth $\mathrm{C}_{n} \mathrm{H}_{2 n_{-} 8}$, the density of the last fraction and its boiling point being extremely high. A hydrocarbon of the $\mathrm{C}_{n} \mathrm{H}_{2 n}$ series, of very similar molecular weight, has also been separated by the writer from Trinidad asphalt and found to have the following physical characteristics:

Boiling point. $147^{\circ}-170^{\circ}$ at $30 \mathrm{~mm}$.

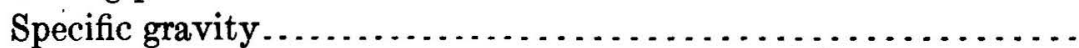

Baumé.

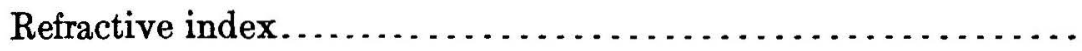

1. 465

Carbon

Hydrogen

86. 85 per cent. 13. 34 per cent.

The resemblance between the physical properties and ultimate composition of these fractions with some of those obtained by Mabery renders it probable that the same series are present in Trinidad asphalt as in California oil. The latter oil is without doubt extremely asphaltic in nature, as is evident from the fact that it leaves 45 per cent of hard pitch, resembling asphalt, on distillation in vacuo.

On distillation with steam of the sludge obtained from treating the above distillates with strong sulphuric acid, the sulphur derivatives of the petroleum, the presence of which is shown by the ultimate analysis, have been recovered by the writer and found to correspond to those obtained in Canadian oil.

On treatment of the distillates with dilute sulphuric acid, one to four, the nitrogen derivatives, the presence of which is also shown by the ultimate analysis, can be recovered. They are probably hydroquinolenes. Their examination has been undertaken by Mabery. $a$ He finds that fractions of the nitrogenous oil, separated by repeated distillation, have the following composition:

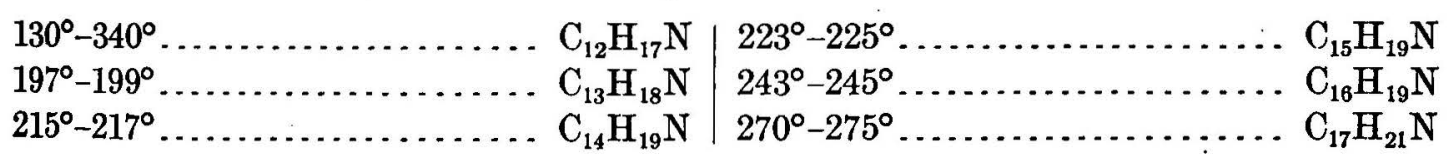

\section{ANALYSES.}

The subjoined analyses of two Summerland oils, to which have been added for comparison the analyses of typical oils from other California districts, show the general character of the petroleums under discussion. This table is followed by several others showing the results of various analyses and distillation tests, which are useful as indicating the properties of the Summerland oils. 
Chemical analyses of California petroleum. ${ }^{a}$

[By H. N. Cooper, chemist. Data and samples collected by Marion Aubury, field assistant.]

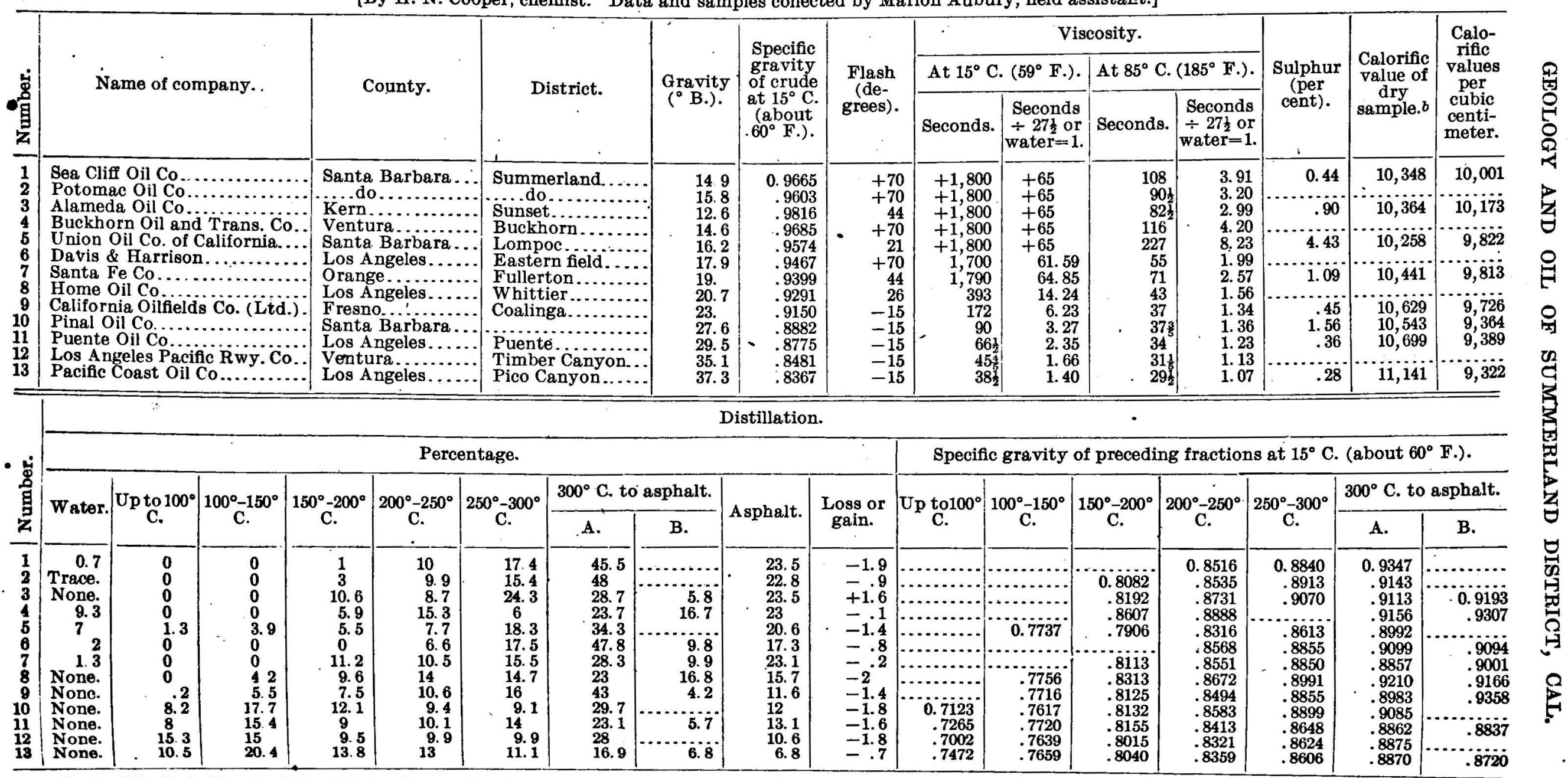

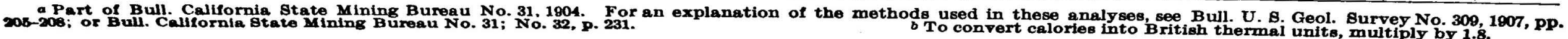


PHYSICAL AND CHEMICAL PROPERTIES OF THE OIL.

Fractional distillations of five Summerland oils and four other California oils.

[By W. L. Watts, Bull. California State Mining Bureau No. 11, 1897, pp. 67-69.]

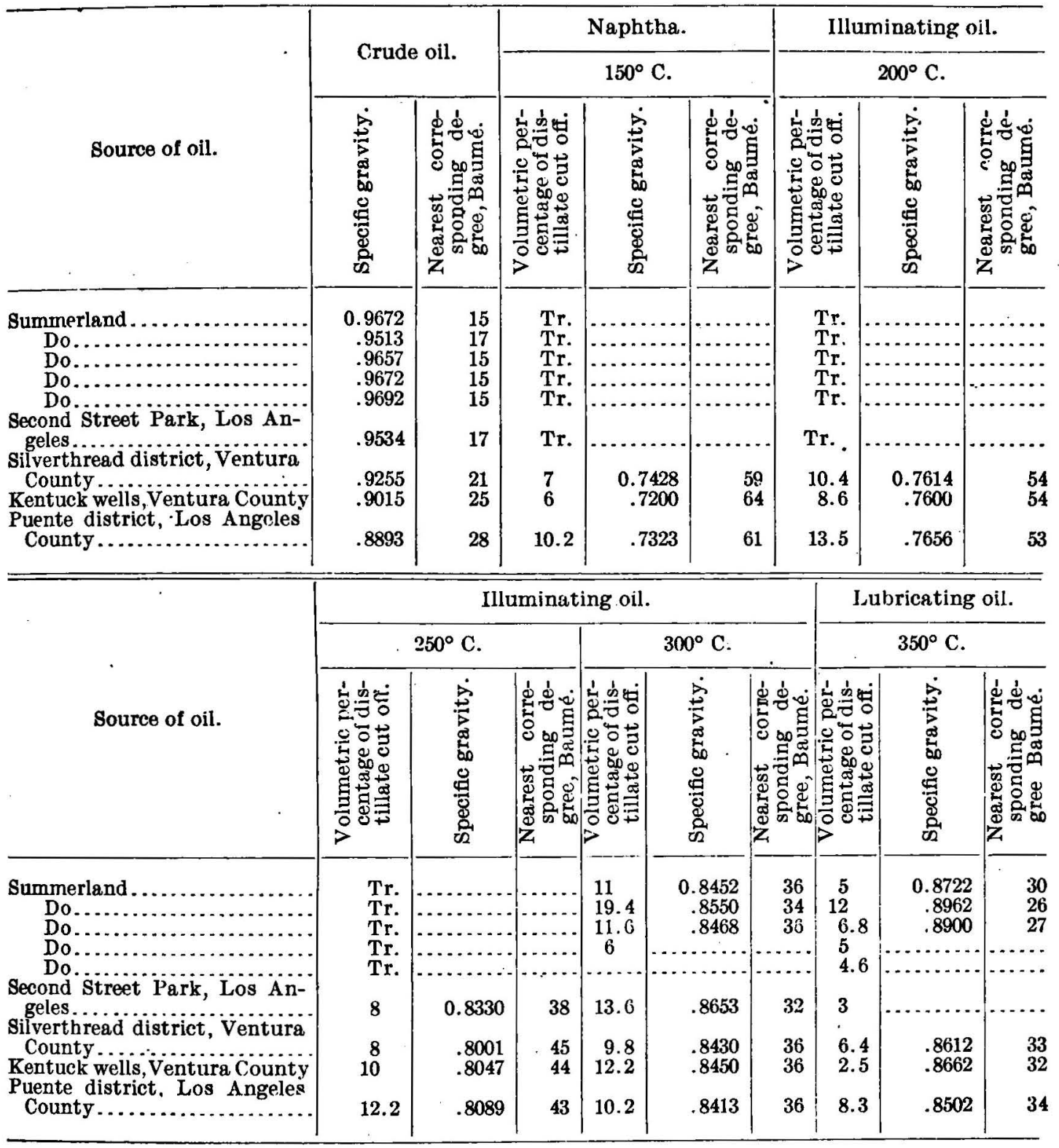

Proximate analysis of a $15^{\circ}$ Baumé Summerland oil.a

DISTILLATION.

\begin{tabular}{|c|c|c|c|c|c|}
\hline$\cdot$ & Per cent. & $\begin{array}{l}\text { Gravity } \\
\text { (ºumé). }\end{array}$ & & Per cent. & $\begin{array}{l}\text { Gravity } \\
\text { (० Baumé). }\end{array}$ \\
\hline $\begin{array}{l}\text { Below } 150^{\circ} \mathrm{C} \ldots \ldots \ldots \ldots \ldots \\
150^{\circ}-270^{\circ} \mathrm{C}, \ldots \ldots \ldots \ldots \\
\text { Above } 270^{\circ} \mathrm{C} \ldots \ldots \ldots \ldots\end{array}$ & $\begin{array}{r}0 \\
10 \\
54\end{array}$ & $\begin{array}{l}35.4 \\
22.2\end{array}$ & $\begin{array}{l}\text { Asphait } \ldots \ldots \ldots \ldots \ldots \ldots \\
\text { Loss } \quad \ldots \ldots \ldots \ldots \ldots \ldots\end{array}$ & $\begin{array}{r}32 \\
3.8\end{array}$ & $\begin{array}{c}\text { E. } \\
\ldots \ldots \ldots\end{array}$ \\
\hline
\end{tabular}

a Prutzman, P. W., Bull. Californa State Mining Bureau No. 32, 1904, p. 198.

CALCULATED ANALYSIS.

\begin{tabular}{|c|c|c|c|c|c|}
\hline 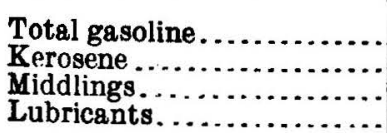 & $\begin{array}{r}0 \\
3 \\
28.5 \\
40.5\end{array}$ & $\begin{array}{l}40 \\
40 \\
33.4 \\
18\end{array}$ & 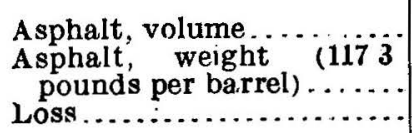 & $\begin{array}{l}32.2 \\
35 \\
3.8\end{array}$ & $\begin{array}{ll}\ldots \ldots \ldots \\
\cdots \ldots \ldots \ldots\end{array}$ \\
\hline
\end{tabular}

1783-Bull. $321-07-5$ 


\section{Proximate analysis of a Summerland oil.a}

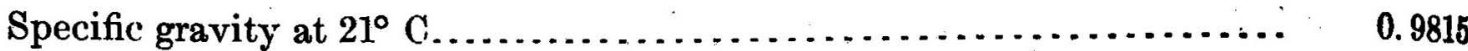

Corresponding degree Baumé .................................. 12.7

Specific viscosity at $152^{\circ} \mathrm{C} .\left(60^{\circ} \mathrm{F}.\right) \ldots \ldots \ldots \ldots \ldots \ldots \ldots \ldots \ldots \ldots \ldots \ldots \ldots \ldots \ldots \ldots, 462.83$

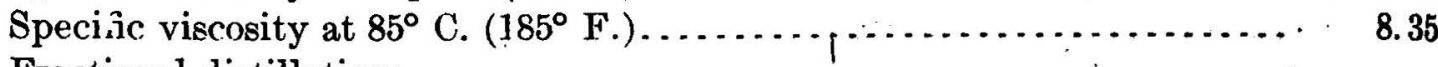

Fractional distillation:

\begin{tabular}{|c|c|}
\hline per cent.. & 25.00 \\
\hline Below $100^{\circ}$ C. $\left(212^{\circ}\right.$ F. $)$......... & .00 \\
\hline $100^{\circ}-150^{\circ}$ C. $\left(212^{\circ}-302^{\circ}\right.$ F. $) . . . .$. & .00 \\
\hline $150^{\circ}-250^{\circ}$ C. $\left(302^{\circ}-482^{\circ}\right.$ F. $) \ldots \ldots . . .$. & 6.50 \\
\hline $250^{\circ}-350^{\circ}$ C. $\left(482^{\circ}-662^{\circ}\right.$ F.)........... & 17. 10 \\
\hline $350^{\circ} \mathrm{C} .\left(662^{\circ} \mathrm{F}.\right)$ to asphalt.......... & 27.50 \\
\hline Asphalt. . . & 22.50 \\
\hline Loss.... & 1.40 \\
\hline
\end{tabular}

Distillation test of $14^{\circ}$ Baumé (tank average) Summerland oil.b

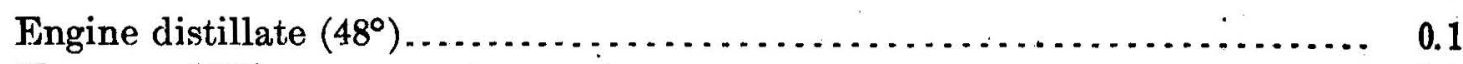

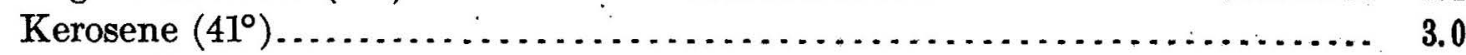

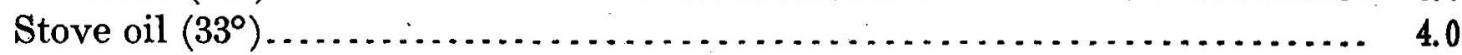

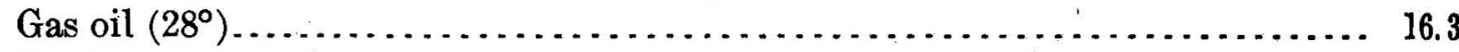

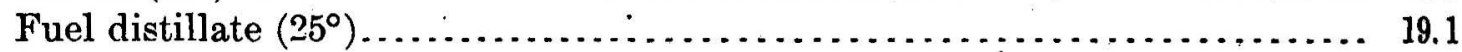

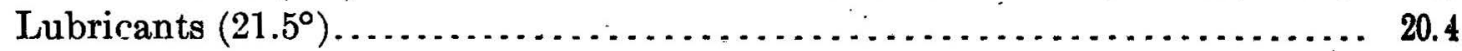

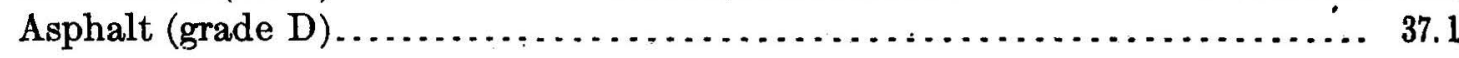

Sample slightly heavier than the average oil of the Summerland district.

Incidental constituents of Summerland crude oil.c

\begin{tabular}{|c|c|c|}
\hline Constituents. & $\mid \begin{array}{c}\text { Gravity } \\
\left({ }^{\circ} \text { Baume }\right) .\end{array}$ & Per cent. \\
\hline $\begin{array}{l}\text { Nitrogen } \\
\text { Sulphur } \\
\text { A sphaltene. }\end{array}$ & $\begin{array}{rr}. & 15 \\
& 15\end{array}$ & $\begin{array}{l}0.850 \\
.898 \\
3.36\end{array}$ \\
\hline
\end{tabular}

TECHNOLOGY AND PRODUCTION.

COST OF DRILLING WELLS AND PRODUCING THE OIL.

Cost of dritling.-The cost of drilling in the Summerland field is not great, owing to the shallowness of the wells and the softness of the strata overlying the oil sands. Watts ${ }^{d}$ is authority for the statement that the cost of drilling, exclusive of the cost of the casing, averages about $\$ 1$ a foot. The following statement shows the detailed cost (exclusive of the wharf) of two wharf wells near the east end of the field:

Cost of 225-foot well, Summerland.

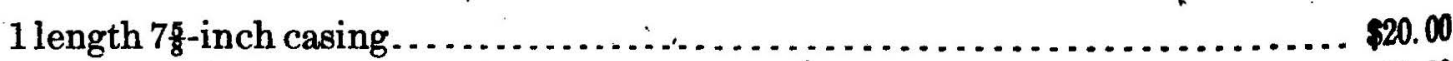

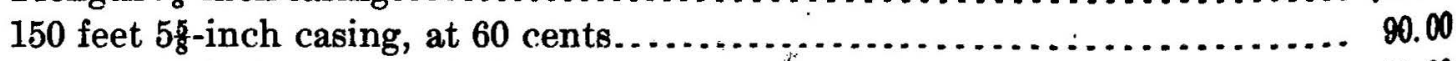

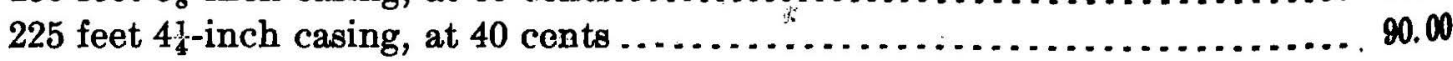


232 feet 2-inch tubing, at 23 cents.

$\$ 53.36$

Drilling 230 feet, at 80 cents ................................. 184. 00

Derrick............................................... 12.00

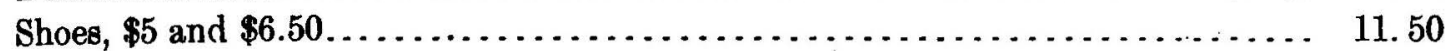

Pump............................................. 18.00

Sucker rods, at $\$ 6.20$ per hundred feet.......................... 14.50

493. 36

Cost of 250-foot well, Summerland.

Conductor, $9 \frac{5}{8}$-inch, 20 feet...................................... $\$ 30.00$

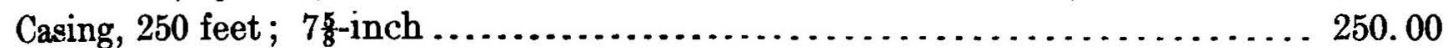

Casing, about 250 feet, 2 -inch pipe, at 23 cents $\ldots \ldots \ldots \ldots \ldots \ldots \ldots \ldots \ldots \ldots . \ldots \ldots$

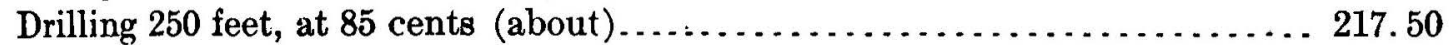

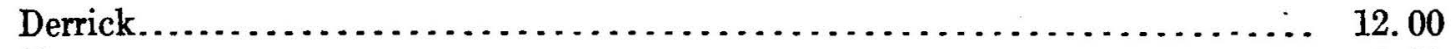

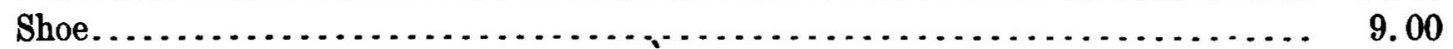

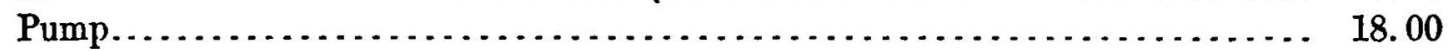

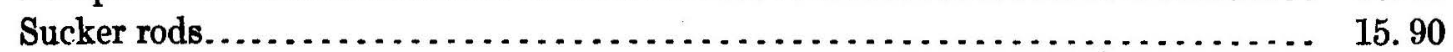

611.51

Cost of producing the oil.- - The cost of production varies throughout the field, owing to the variations in the yield of each well, in the quantity of water and sand that is pumped with the oil, etc. In general, however, the cost ranges from 25 to 30 cents a barrel, although it is said to be as high as 40 cents in some of the wells.

\section{SEPARATION OF SAND AND WATER FROM OIL.}

The separation of the sand from the oil is accomplished by means of a "sand box," into which the oil is run and in which a large portion of the sand settles. The "sand box" consists of a wooden trough divided by two or more upright partitions that run across it. At the top of the partitions are notches through which the oil passes, and the sand is deposited at the bottom. The oil is run into a tank, at the bottom of which a space of 10 inches or more is allowed for any sand which may still be in it.

Heat accelerates the separation of the water from the oil, and in order to apply it to the emulsion which comes from the pumps, the emulsion is allowed to stand for about twelve hours in tanks containing coils of steam pipes. In these tanks the water settles to the bottom while the oil rises to the top, and each is conveyed separately from the tank. As a substitute for the heating tank one operator heats his oil in its passage from the wells to the settling tanks by passing it through three turns of pipe in a steam-heated chamber consisting of 20 feet of large casing. The chamber is heated by steam from the pump exhaust. 


\section{PRODUCTION.}

The total production of the Summerland field from 1895 to January 1,1907 , exclusive of 1896 , was $1,373,980$ barrels. The field reached its maximum yield in 1899 , when it produced 208,370 barrels of crude petroleum. Since that time the yield has been gradually falling off on account of the natural decline in production of the individual wells and the cessation of drilling operations, and also because of adverse market and transportation facilities. In the early history of the field three to five year contracts for 90 cents a barrel were obtainable; now the producers can barely get enough to cover the cost of production.

The following table shows the production by years from 1895 to 1906 , inclusive.

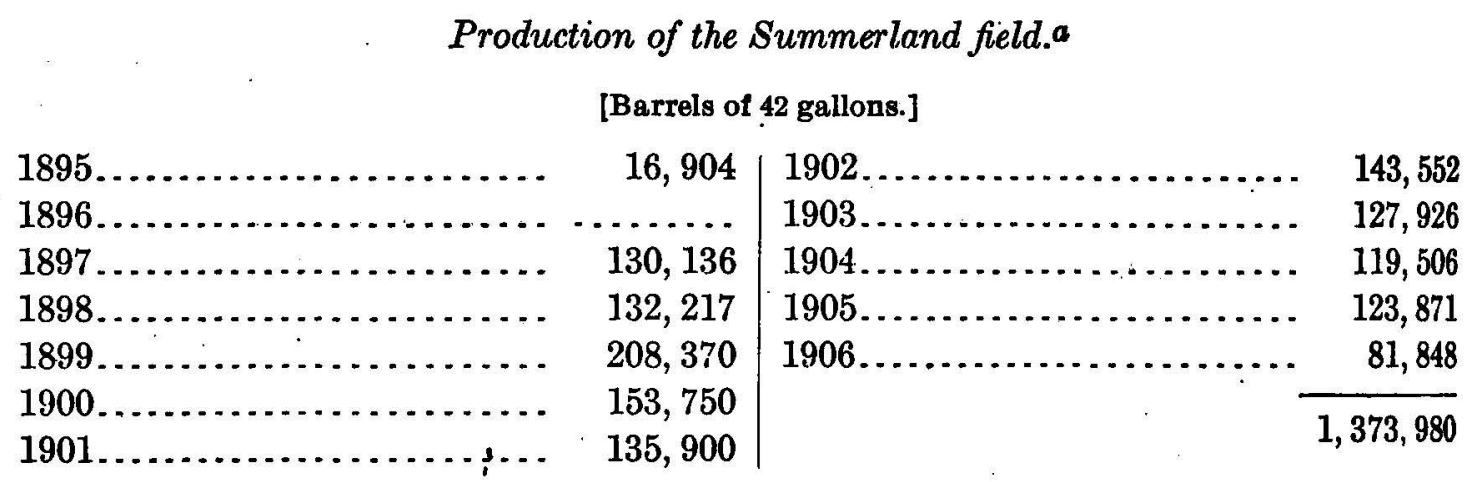

\section{UTILIZATION AND TRANSPORTATION.}

Most of the oil now produced in this field, with the exception of that coming from the Southern Pacific Company's wells, is used locally, either in the Summerland refinery or for oiling roads or for fuel in the vicinity of Santa Barbara. At one time much of the oil was shipped to Los Angeles and elsewhere over the Southern Pacific Railroad, but a combination of high freight rates with a poor market has practically stopped exportation.

\section{REFINERY.}

One refinery, that of the California Liquid Aspnalt Company, is located at Summerland. It is equipped with two stills and has a still capacity of 300 barrels of crude oil. Summerland oil is used entirely, distillates and asphalt being the products. A higher percentage of asphalt is derived from the oil from this field than is found in any of the other California oils.

The following companies were engaged in the production of oil at Summerland January 1, 1907:

a With the exception of the figures for 1895, which are from Bull. California State Mining Bureau Na. 11,1897 , p. 57 , the figures of production were furnished by the division of mining and mineral recources, U. S. Geol. Survey. 
COMPANIES NOW OPERATING.

G. F. Becker Oil Company.

Knapp \& Hassinger (Royal Oil Company).

J. C. Lillis.

Lillis Oil Company.

Montecito Improvement Company.

Miller \& McFarland.

North Star Oil Company (J. C. Lillis).

Oxnard Oil Company.

Potomac Oil Company.

Sea Cliff Oil Company.

Sea Side Oil Company.

Southern Pacific Railroad Company (Kern Trading and Oil Company).

Sunset Oil Company.

J. C. Wilson. 

PLATES IX TO XVII. 


\section{PLATE IX.}

\section{Topatopa (Eocene) Fossils.}

(Unless otherwise indicated all figures are natural size.)

Fig. 1. Meretrix uvasana Conrad." Pal. California, vol. 1, 1864, pl. 30, fig. 248. Right valve; longitude, $55 \mathrm{~mm}$. A common species in the Eocene.

Fig. 2. Ostrea idriaensis Gabb, type. Pal. California, vol. 2, 1868, pl. 34, fig. 103. Exterior of right valve; altitude, $58 \mathrm{~mm}$. A common species in the Eocene of the Santa Cruz Mountains.

Fig. 3. Venericardia planicosta Lamarck, U.S.N.M. 164973. Left valve; longitude, $84 \mathrm{~mm}$. Eocene, Little Falls, Wash. This is the most widespread and characteristic Eocene species in the world.

Fig. 4. Phacoides cretacea Gabb, U.S.N.M. 165254. Cast of right valve of a mediumsized specimen; altitude, $18 \mathrm{~mm}$; view of exterior, $\times 2$. Topatopa formation near head of West Fork of Sycamore Canyon, Santa Barbara.

Fig. 5. Cardium brewerii Gabb, type. Right valve; altitude, $61 \mathrm{~mm}$.; view of exterior natural size. Pal. California, vol. 1, 1864, pl. 24, fig. 155. A common species in the Eocene of the Santa Ynez Mountains. 

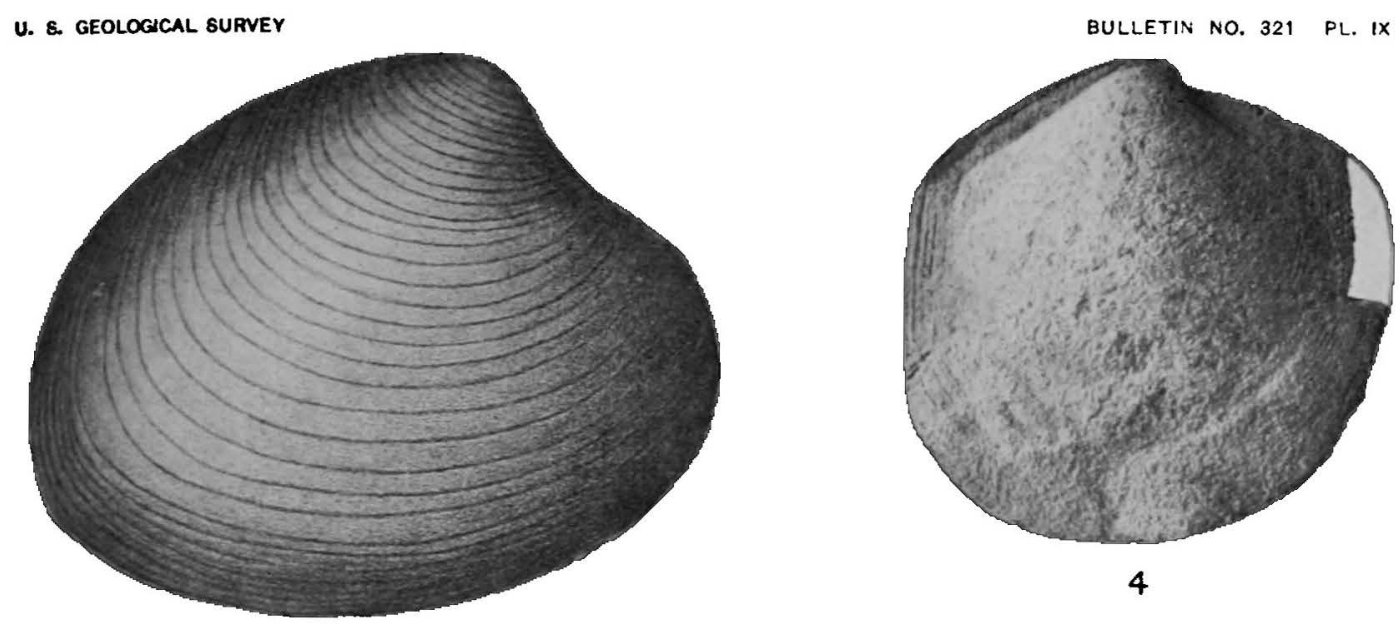

1
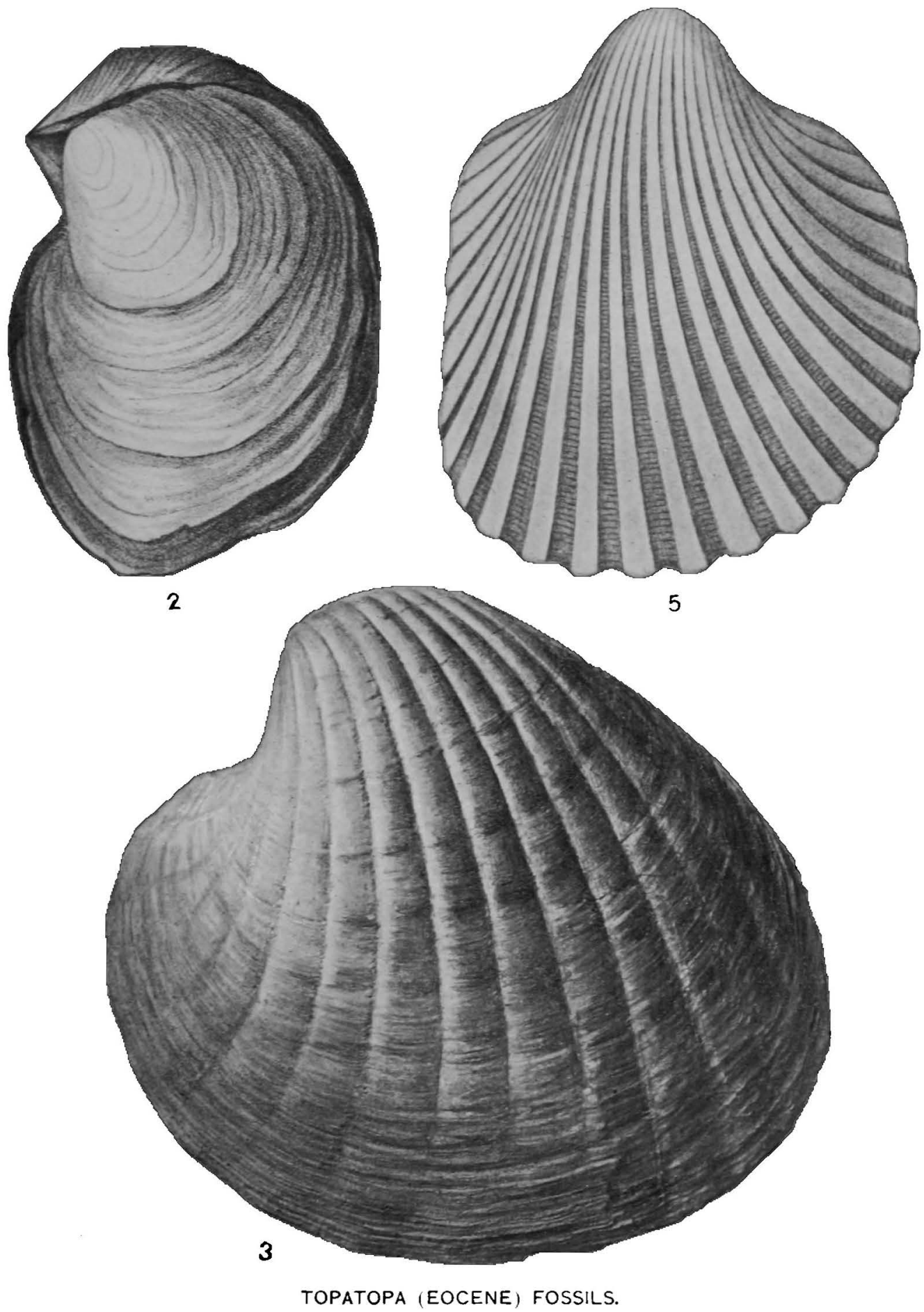

TOPATOPA (EOCENE) FOSSILS. 




\section{PLA'TE X.}

\section{Topatopa (Eocene) and Monterey (Mrocene) Fossils.}

(Unless otherwise indicated all figures are natural size.

Fig. 1. Leda gabbi Conrad. Pal. California, vol. 1, 1864, pl. 26, fig. 185. Longitude, $18 \mathrm{~mm}$; enlarged. A common species in the Eocene.

Frg. 2. Fusus occidentalis Gabb, type. Altitude, $15 \mathrm{~mm}$; back view, $\times 2$. Pal. California, vol. 2, 1868, pl. 26, fig. 23. Abundant in the Eocene of the - Santa Ynez Range.

Fig. 3a. Galerus excentricus Gabb, U.S.N.M. 165258. Internal cast of a fairly representative specimen; altitude, $14 \mathrm{~mm}$; view of side, $\times 2$. Topatopa formation, near head of West Fork of Sycamore Canyon, Santa Barbara.

Fig. 3b. View of top of same specimen, $\times 2$.

Fra. 4. Modiolus ornatus Gabb. Right valve; longitude, $38 \mathrm{~mm}$. Pal. California, vol. 1, 1864, pl. 24, fig. 166: A common species in the California Eocene.

Fig. 5. Meretrix uvasana Conrad, U.S.N.M. 165253. Cast of right valve of a young specimen; longitude, $15 \mathrm{~mm}$; ; view of exterior, $\times 2$. Topatopa formation, near head of West Fork of Sycamore Canyon, Santa Barbara.

Fra. 6. Mactra near ashburnerii Gabb, U. S. N. M. 165257. An internal cast of left valve; longitude, $20 \mathrm{~mm}$; ; view of front, $\times 2$. Topatopa formation, near head of West Fork of Sycamore Canyon, Santa Barbara.

Frg. 7. Turritella uvasana Conrad, U. S. N. M. 165255. An imperfect cast; altitude, $33 \mathrm{~mm}$. Topatopa formation, near head of West Fork of Sycamore Canyon, Santa Barbara.

Fra. 8. Spirocrypta pileum Gabb. Pal. California, vol. 1, 1864, pl. 29, fig. 233. Longitude, $13.5 \mathrm{~mm}$.; view of side, enlarged. A common form in the Eocene.

FIG. 9a. Spirocrypta pileum Gabb, U. S. N. M. 165256. Internal cast; longitude, 22 $\mathrm{mm}$.; view of top $\times 2$. Topatopa formation, near head of West Fork of Sycamore Canyon, Santa Barbara.

Fra. $9 b$. View of side of same specimen, $\times 2$.

Fre. 10. Pecten peckhami Gabb, U. S. N. M. 164839. Cast of right and left valves in matrix. Monterey shale (middle Miocene), southeast of Pinole, Contra Costa County, Cal. A common species in the Monterey shale of the Cosat Range. 
U. 8. GEOLOGICAL SURVEY

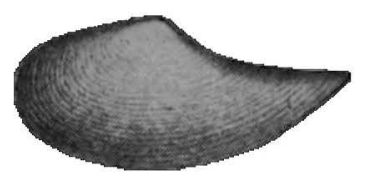

1

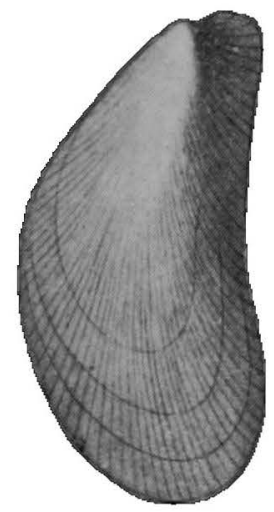

4

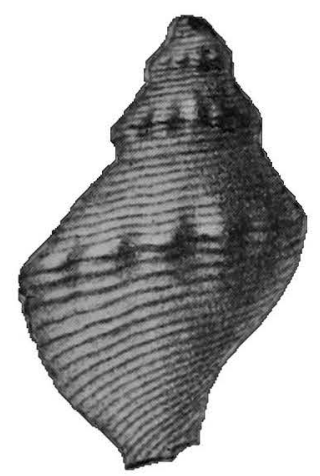

2

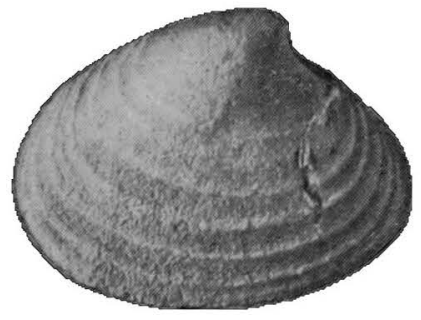

5
BULLETIN NO.321 PL $X$
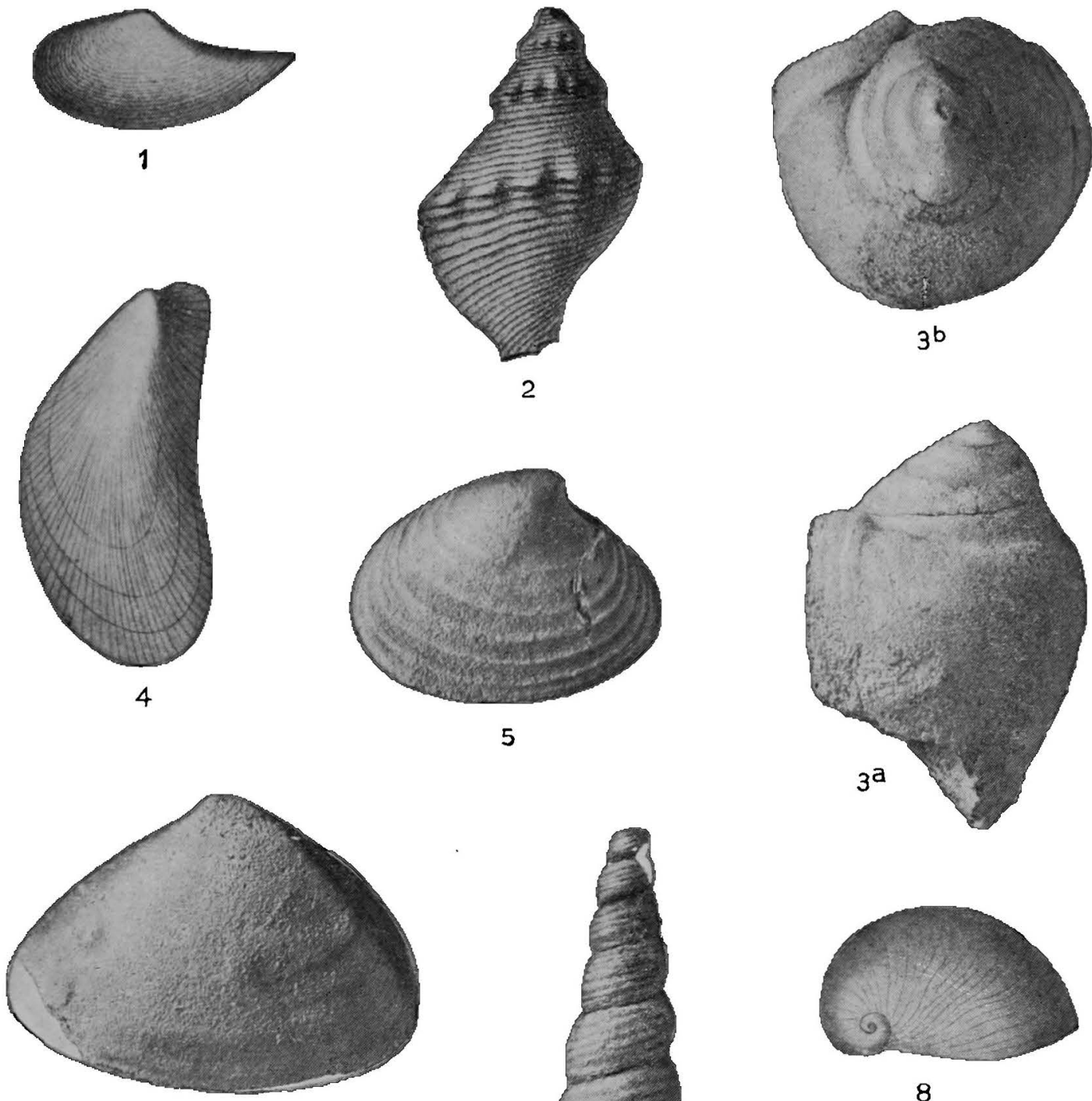

6

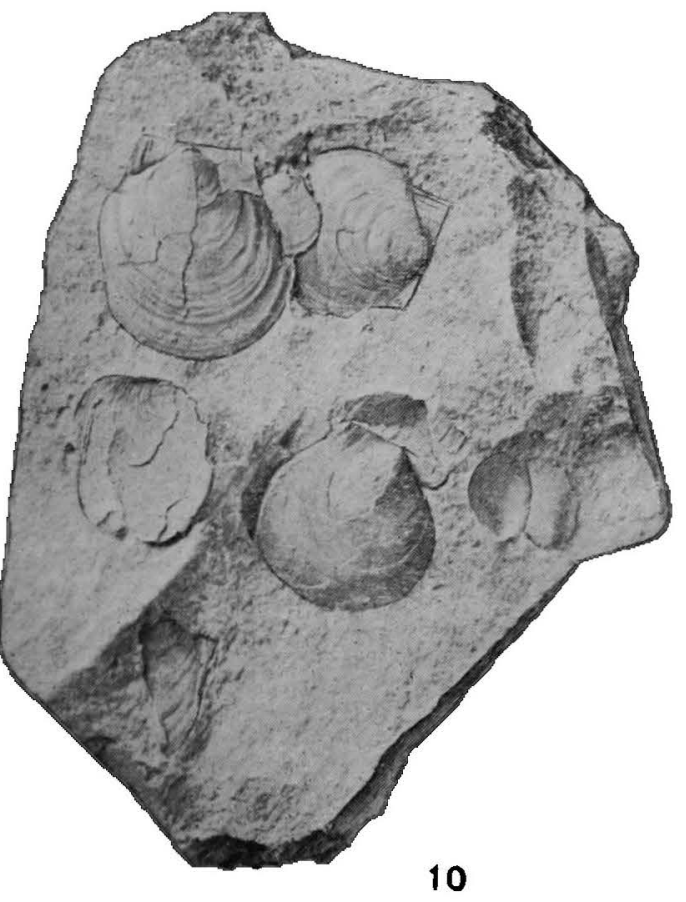

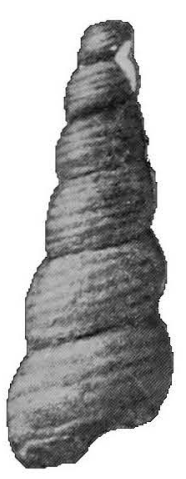

7

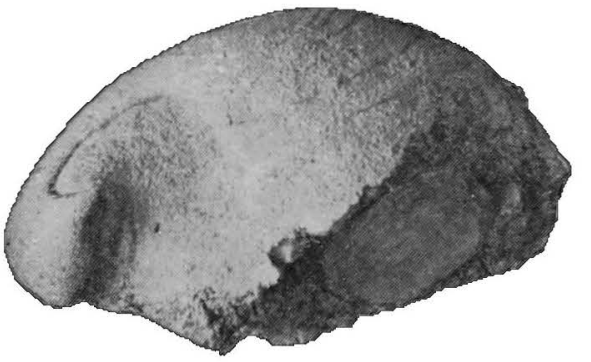

$9^{b}$

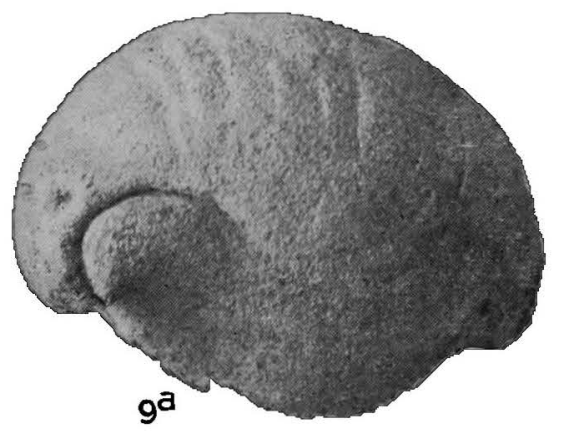

TOPATOPA (EOCENE) AND MONTEREY (MIOCENE) FOSSILS. 




\section{PLATE XI. \\ Fernando (Pliocene) Gasteropoda.}

(All specimens are from Fernando formation, Bath-house Beach, Santa Barbara. Unless otherwise indicated, all figures are natural size.)

Fra. 1. Mitramorpha filosa Carpenter, var. barbarensis Arnold, U. S. N. M. 165245 (type). Altitude, $6.5 \mathrm{~mm}$; ; aperture view, $\times 4$. Characteristic of this horizon.

Fig. 2. Lacuna compacta Carpenter, U. S. N. M. 165235. Altitude, 6.5 mm.; aperture view, $X 4$. Also known recent.

Fig. 3. Leptothyra bacula Carpenter, U.S. N. M. 165236. Diameter, 3 mm.; aperture view, $X 6$. Also known recent.

Frg. 4. Mangilia tabulata Carpenter, U. S. N. M. 165240. Altitude, 4 mm.; aperture view, $\times 4$. Also known recent.

Fra. 5a. Puncturella delosi Arnold, U. S. N. M. 165234 (type). Altitude, 1.9 mm; view of side, $\times 10$. Characteristic of this horizon.

Fig. $5 b$. Rear view of same specimen, $\times 10$.

Fig. 6. Tornatina culcitella Grould, U. S. N. M. 165239. Altitude, 5 mm.; aperture view, $X 4$. Also known recent.

Fic. 7. Amphissa corrugata Reeve, U. S. N. M. 165243. Altitude, 11 mm.; aperture view, $X 3$. Also known recent.

FIG. 8. Nassa perpinguis Hinds, U. S. N. M. 165237. Altitude, $10 \mathrm{~mm}$.; aperture view, $\times 2$. Also known recent.

Fig. 9. Clathurella conradiana Gabb, U. S. N. M. 165247. - Altitude, 11 mm.; aperture view, $X 3$. Also reported as recent, but the recent form is probably another species or variety.

Frg. 10. Columbella (Astyris) tuberosa Carpenter, U. S. N. M. 165242. Altitude, 9 $\mathrm{mm}$; ; aperture view, $\times 3$. Also known recent.

Fro. 11. Ocinebra lurida Middendorf, U. S. N. M. 165233. Altitude, 12 mm.; aperture view, $X 2$. Also known recent.

Fre. 12. Thophon (Boreotrophon) stuarti Smith, U. S. N. M. 165244. Altitude, 20 mm.; aperture view, $\times 2$. Also known recent.

FIG. 13. Bittium catalinensis Bartsch, U. S. N. M. 165232 (type). Altitude, 7 mm.; aperture view, $\times 6$.

Fro. 14. Galerus mammillaris Broderip, U. S. N. M. 165251. Maximum-dismeter, $17 \mathrm{~mm}$.; view of top, $\times 2$. Also known recent.

Fig. 15. Bittium barbarensis Bartsch, U. S. N. M. 165231 (type). Altitude, 8.5 mm.; aperture view, $\dot{X} 6$. 
U. 8. GEOLOGICAL SURVEY

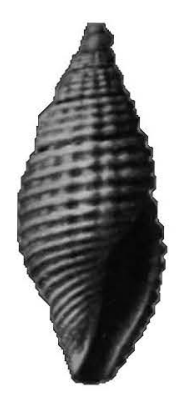

1

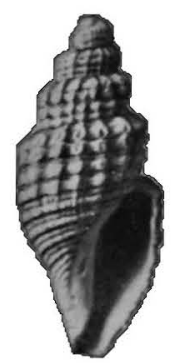

4
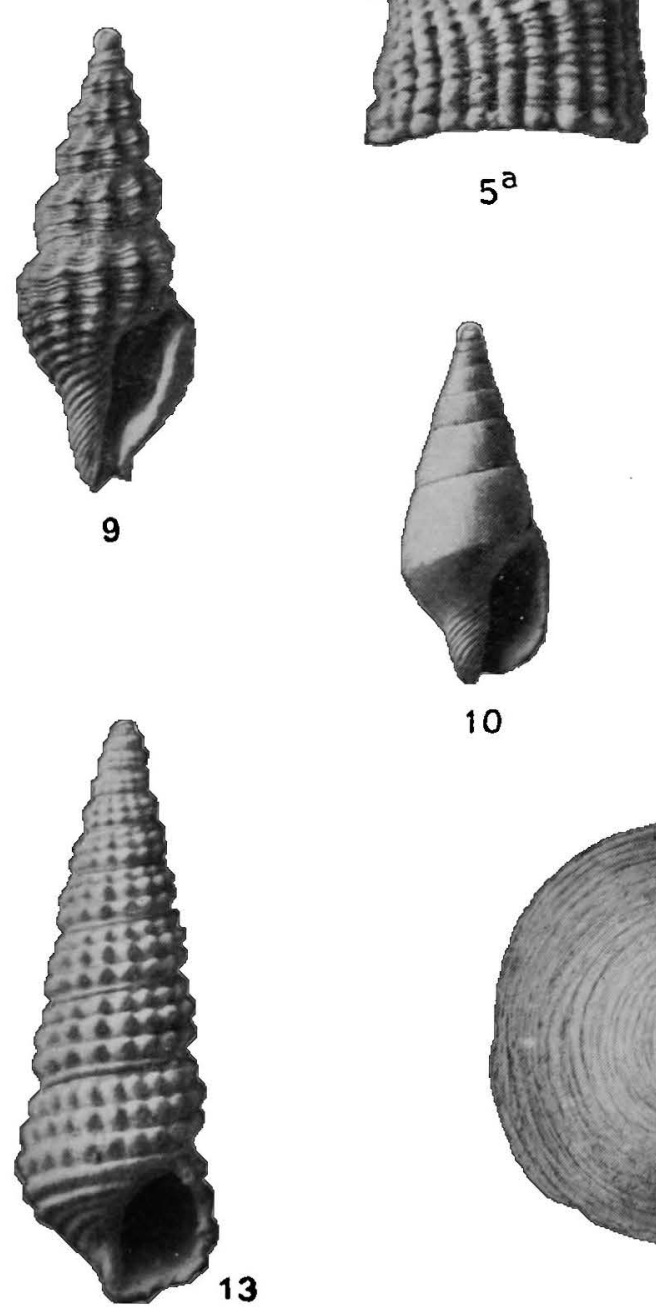

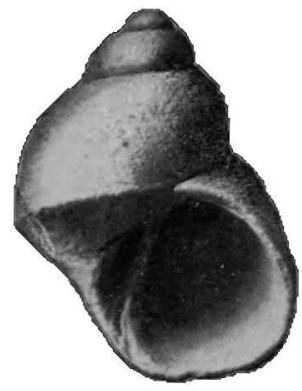

2

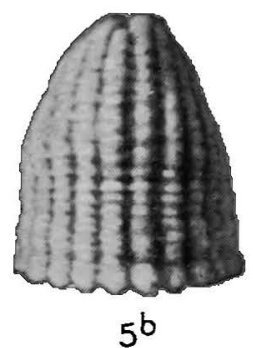

$5^{b}$

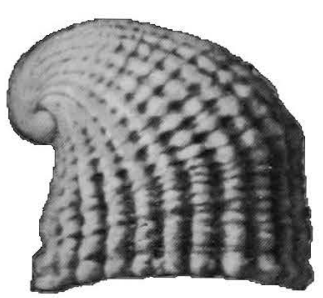

$5^{a}$

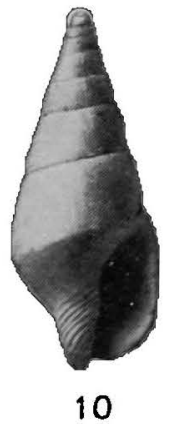

BULLETIN NO. 321 PL. XI

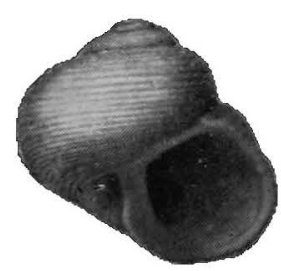

3

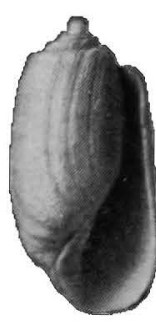

6
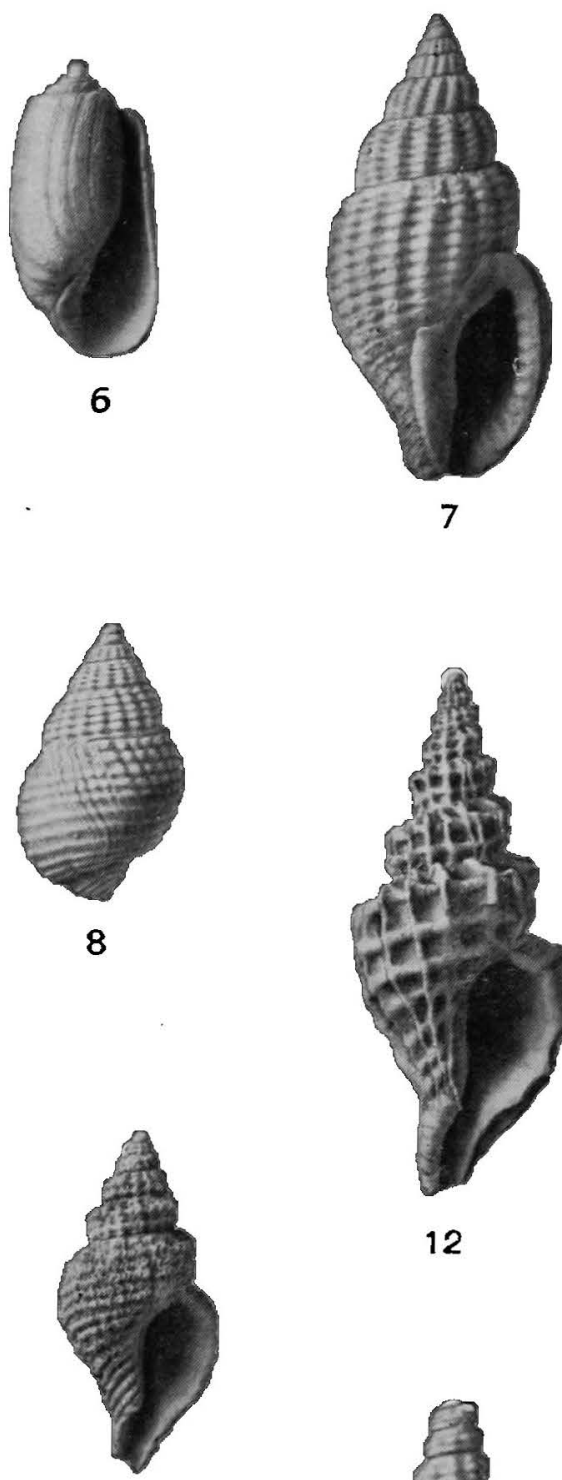

11

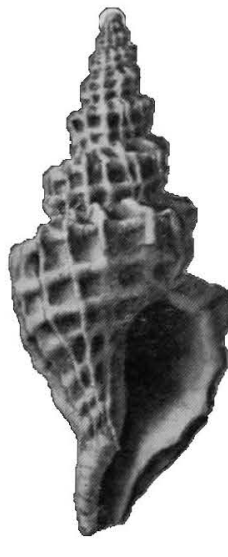

12

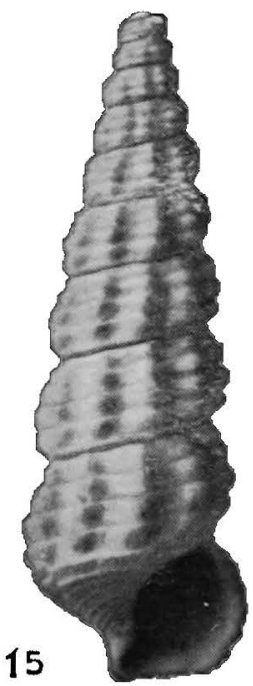

FERNANDO (PLIOCENE) GASTEROPODA. 




\section{PLATE XII.}

\section{Fernando (Pliocene) Pelecypoda and Brachiopoda.}

(Unless otherwise stated, all specimens are from Fernando formation, Bath-house

Beach, Santa Barbara. All figures not otherwise indicated are natural size.)

Fig. 1a. Mercenaria perlaminosa Conrad, U.S.N.M. 165252. Right valve; longitude $87 \mathrm{~mm}$.; view of exterior. Characteristic of this horizon.

Fig. 1b. View of same specimen from front.

Fig. 1c. Mercenaria perlaminosa Gabb, U.S.N.M. 165288. Longitude of fragment, showing hinge of left valve, $56 \mathrm{~mm}$. Characteristic of this horizon.

Frg. 2a. Venericardia yatesi Arnold, U.S.N.M. 165248 (type). Right valve; latitude $4 \mathrm{~mm}$.; view of exterior, $\times 6$. Characteristic of this horizon.

Fic. 2b. View of interior of same specimen.

Fig. 3. Psephidia barbarensis Arnold, U.S.N.M. 165238 (type). Altitude 4 mm.; view of interior, $\times 4$. Characteristic of this horizon.

Frc. 4a. Terebratalia hemphilli Dall, U.S.N.M. 108495 (holotype). Proc. U. S. Nat. Mus., vol. 24, 1902, pl. 40, fig. 10 . Ventral valve; longitude $35 \mathrm{~mm}$.; view of exterior, slightly enlarged. Arroyo Burro, west of Santa Barbara.

Fig. 4b. Exterior of view of dorsal valve of same specimen. Op. cit., pl. 40, fig. 8. 


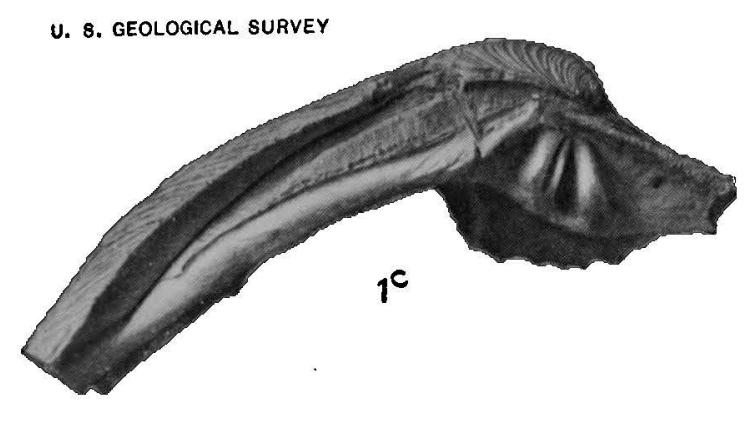

BULLETIN NO. 321 PL. XII
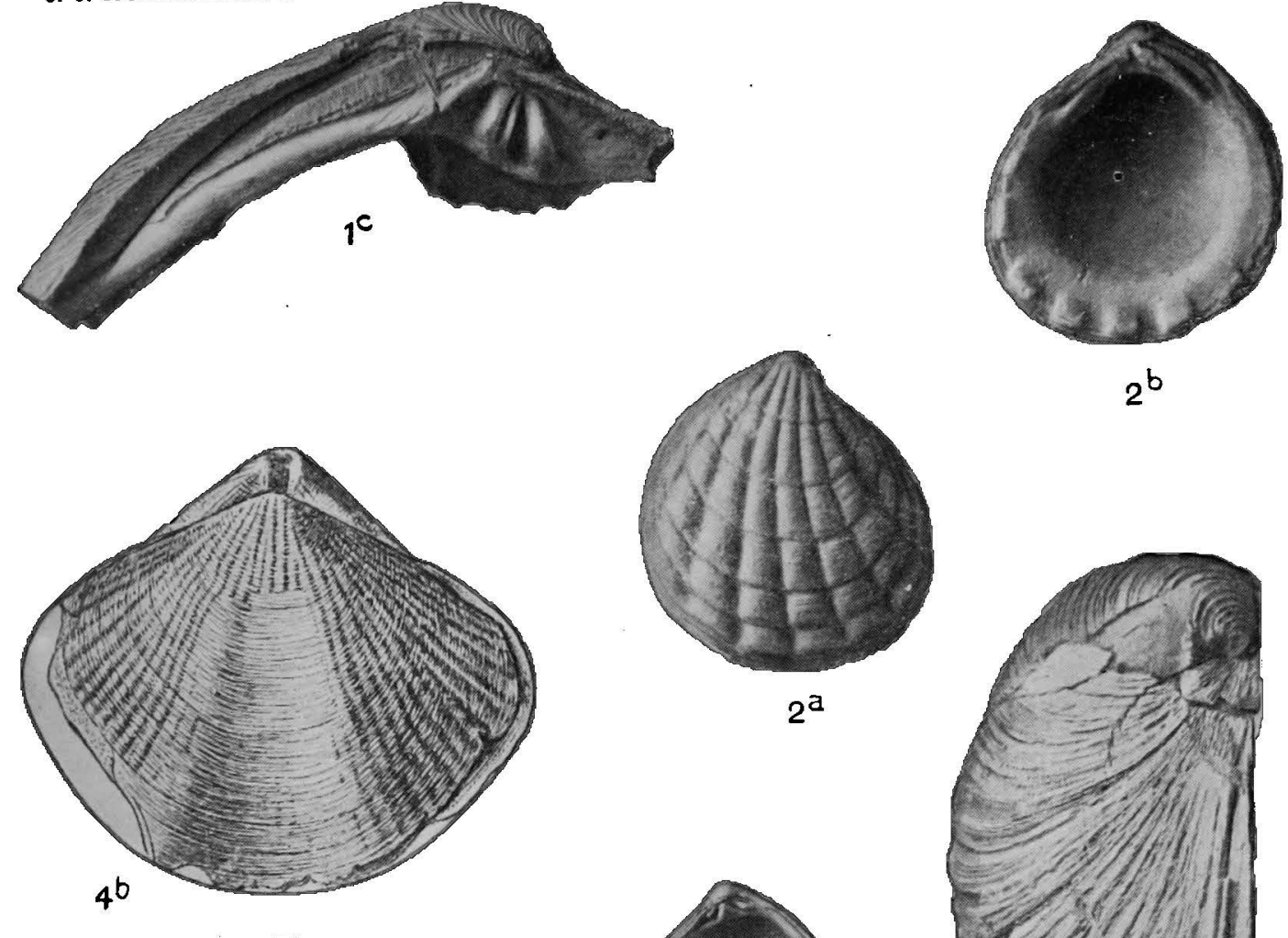

$2^{b}$
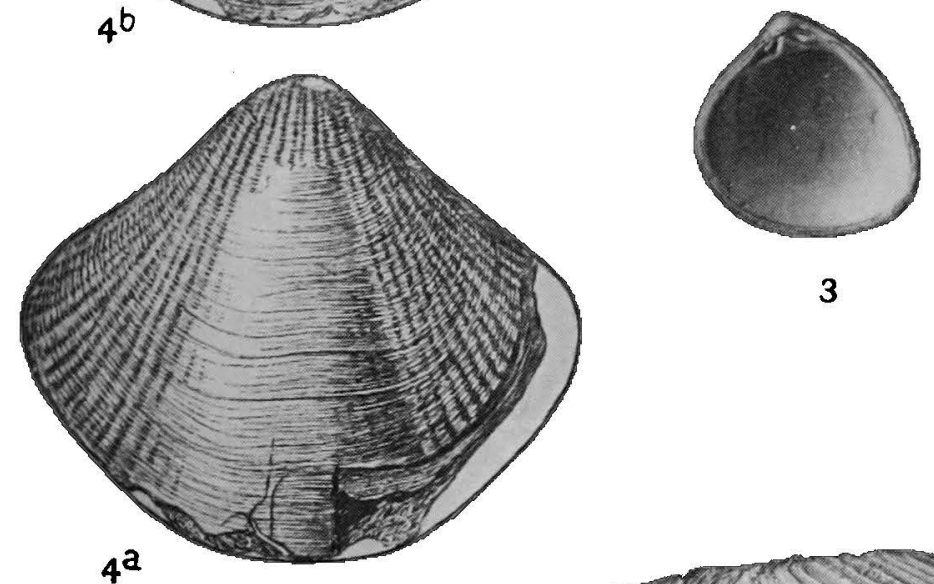

$2^{\mathrm{a}}$
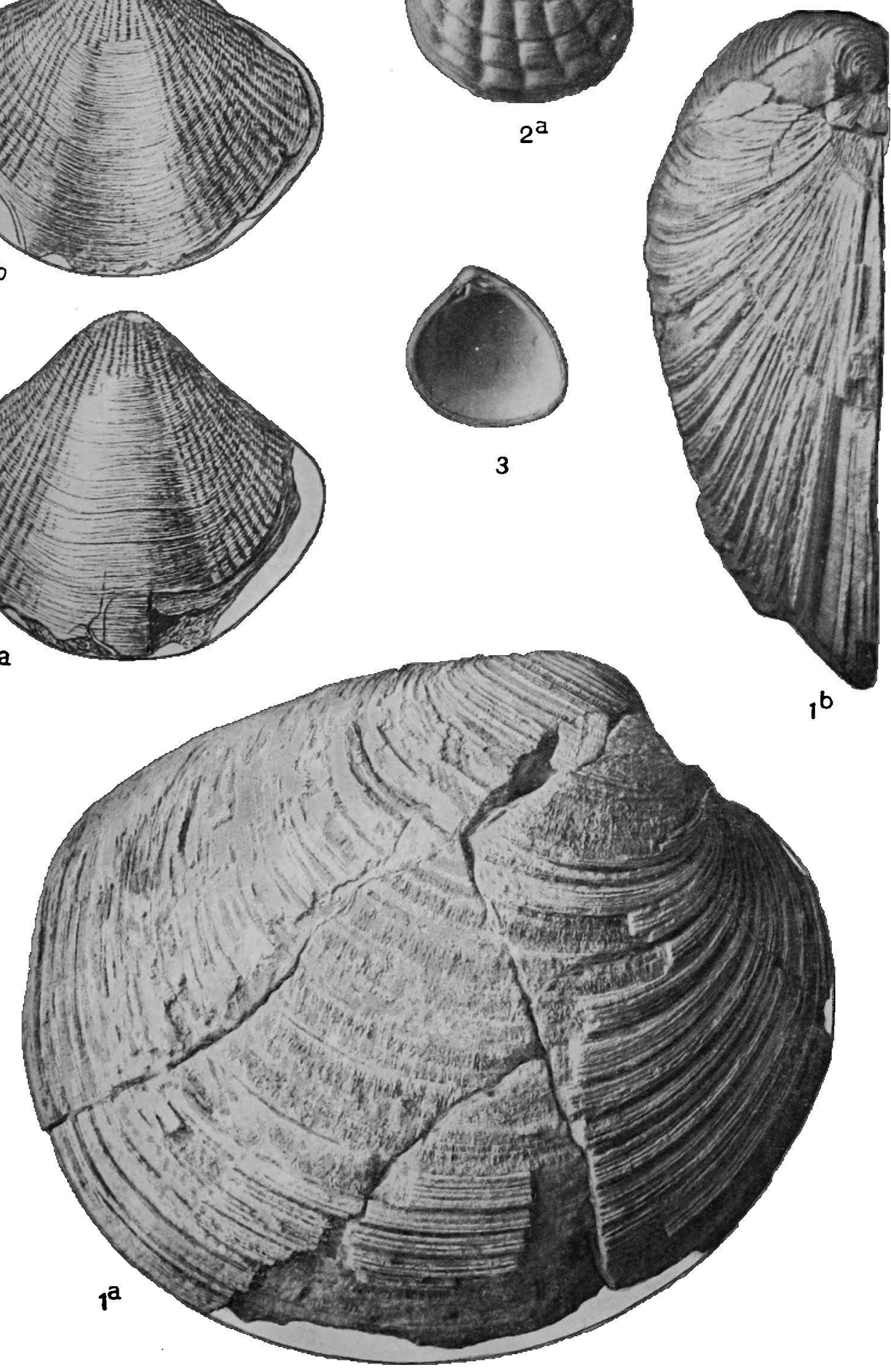

FERNANDO (PLIOCENE) PELECYPODA AND BRACHIOPODA. 




\section{PLATE XIII. \\ Fernando (Pliocene) Gasteropoda.}

(Unless otherwise indicated, all figures are natural size.)

Frg. 1a. Crepidula princeps Conrad, U.S.N.M. 165315. Longitude $106 \mathrm{~mm}$.; view of top. Packards Hill, Santa Barbara; characteristic of the Fernando in Santa Barbara County; also found in the Miocene and Pliocene elsewhere in the State.

Fig. 1b. Side view of same specimen.

Frg. 1c. Interior view of same specimen.

Frg. 2, Natica clausa Broderip and Sowerby, U.S.N.M. 165241. Altitude $7.5 \mathrm{~mm}$.; aperture view, $\times 4$. Fernando formation, Bath-house Beach, Santa Barbara. Also known recent.

Fig. 3. Leptothyra paucicostata Dall, U.S.N.M. 165246. Diameter 4 mm.; aperture view, $\times 6$. Fernando formation, Bath-house Beach, Santa Barbara. Also known recent.

78 


$$
\text { tj }
$$






\section{PLATE XIV. \\ Fernando (Pliocene) Pelecypoda.}

(Unless otherwise indicated, all figures are natural size.)

Frg. 1. Semele pulchra Sowerby, var. montereyi Arnold, U.S.N.M. 165250. Right valve; latitude $18 \mathrm{~mm}$; view of exterior, $\times 2$. Fernando formation, Santa Barbara. Also reported as recent.

Fig. 2. Venericardia monilicosta Gabb, U.S.N.M. 165249. Left valve; altitude 11 $\mathrm{mm}$.; view of exterior, $\times 3$. Fernando formation, Bath-house Beach, Santa Barbara. Characteristic of this horizon.

Fig. 3. Pecten (Chlamys) opuntia Dall, collection of Delos Arnold. Right valve; altitude $43 \mathrm{~mm}$.; view of exterior. Same locality as fig. 4 .

Fig. 4. Pecten (Chlamys) opuntia Dall, collection of Delos Arnold. Left valve; altitude $51 \mathrm{~mm}$.; view of exterior. Fernando formation, Arroyo Burro, Santa Barbara. Characteristic of this horizon.

Frg. 5a. Pecten (Chlamys) jordani Arnold, U.S.N.M. 162522 (type). Exterior of right valve; altitude $45 \mathrm{~mm}$. Pliocene, Deadman Island, near San Pedro, Cal.; also found in the Fernando formation at Santa Barbara and elsewhere.

Fig. $5 b$. Exterior of left valve of same specimen.

Fig. 6a. Pecten (Chlamys) hastatus Sowerby, collection of F. L. Button. Exterior of right valve; altitude $49 \mathrm{~mm}$. Recent, Monterey, Cal.; found abundantly in the Fernando and equivalent formations throughout southern California.

Fra. 6b. Exterior of left valve of same specimen.

Fig. 7. Pecten (Chlamys) hastatus Sowerby, var. strategus Dall, collection of Delos Arnold. Exterior of left valve; altitude $36 \mathrm{~mm}$. Fernando formation, Bath-house Beach, Santa Barbara. Characteristic of the Fernando formar 

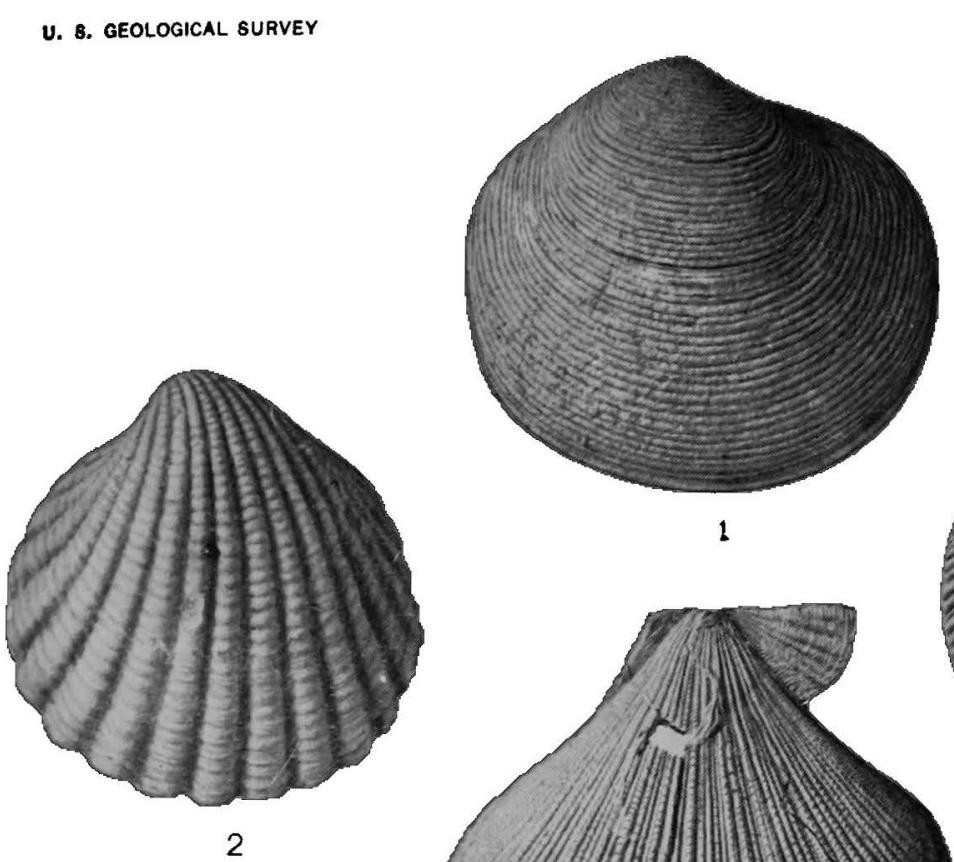

BULLETIN NO. 321 PL. XIV

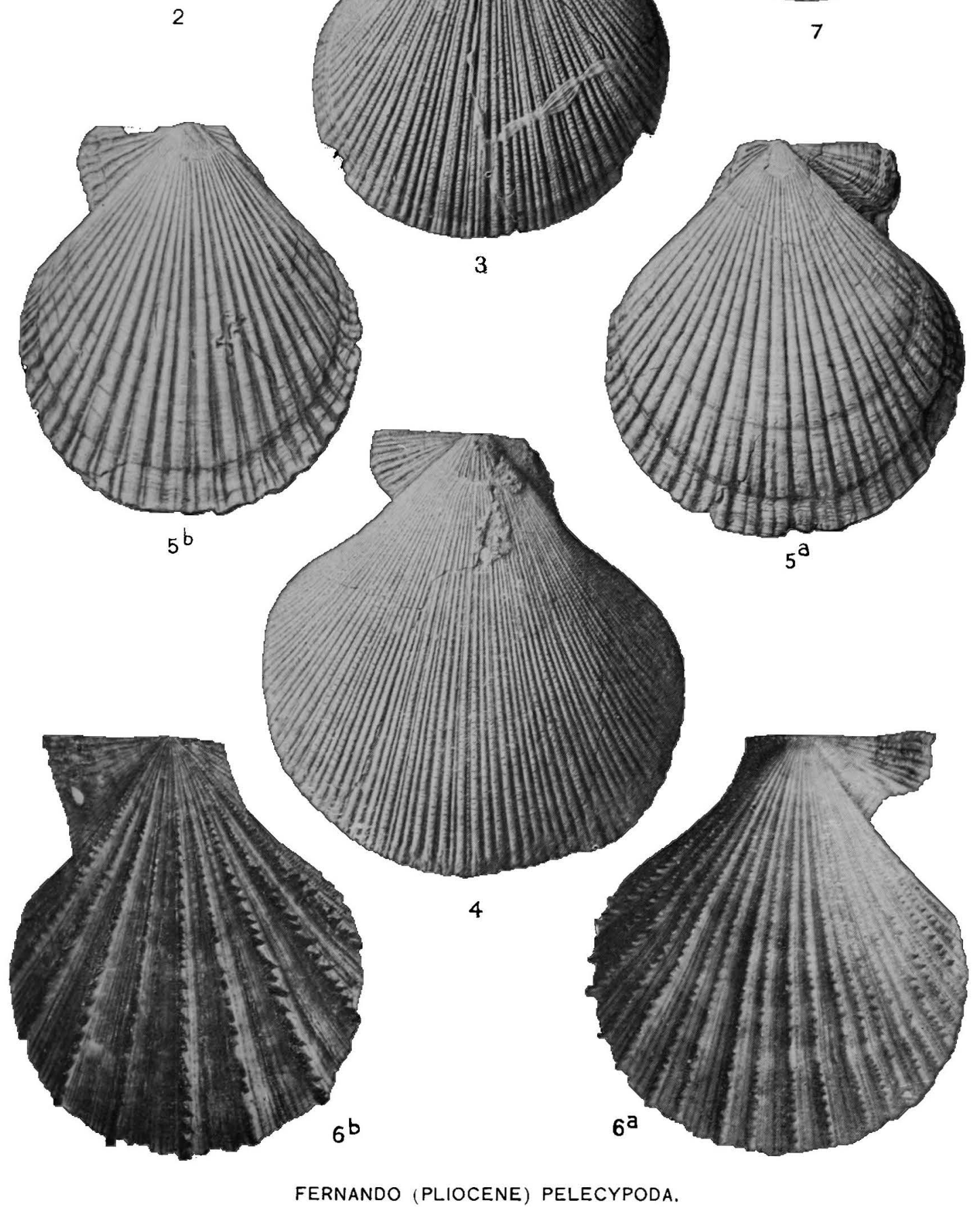






\section{PLATE XV. \\ Fernando (Pliocene) Pecten.}

(Unless: otherwise indicated, all figures are natural size.)

Fig. 1a. Pecten (Pecten) bellus Conrad, U.S.N.M. 165314. Right valve; altitude 92 $\mathrm{mm}$.; view of exterior. Bath-house Beach, Santa Barbara. Characteristic of this region.

Frg. 1b. Left valve of same specimen. Altitude $85 \mathrm{~mm}$.; view of exterior. 82 

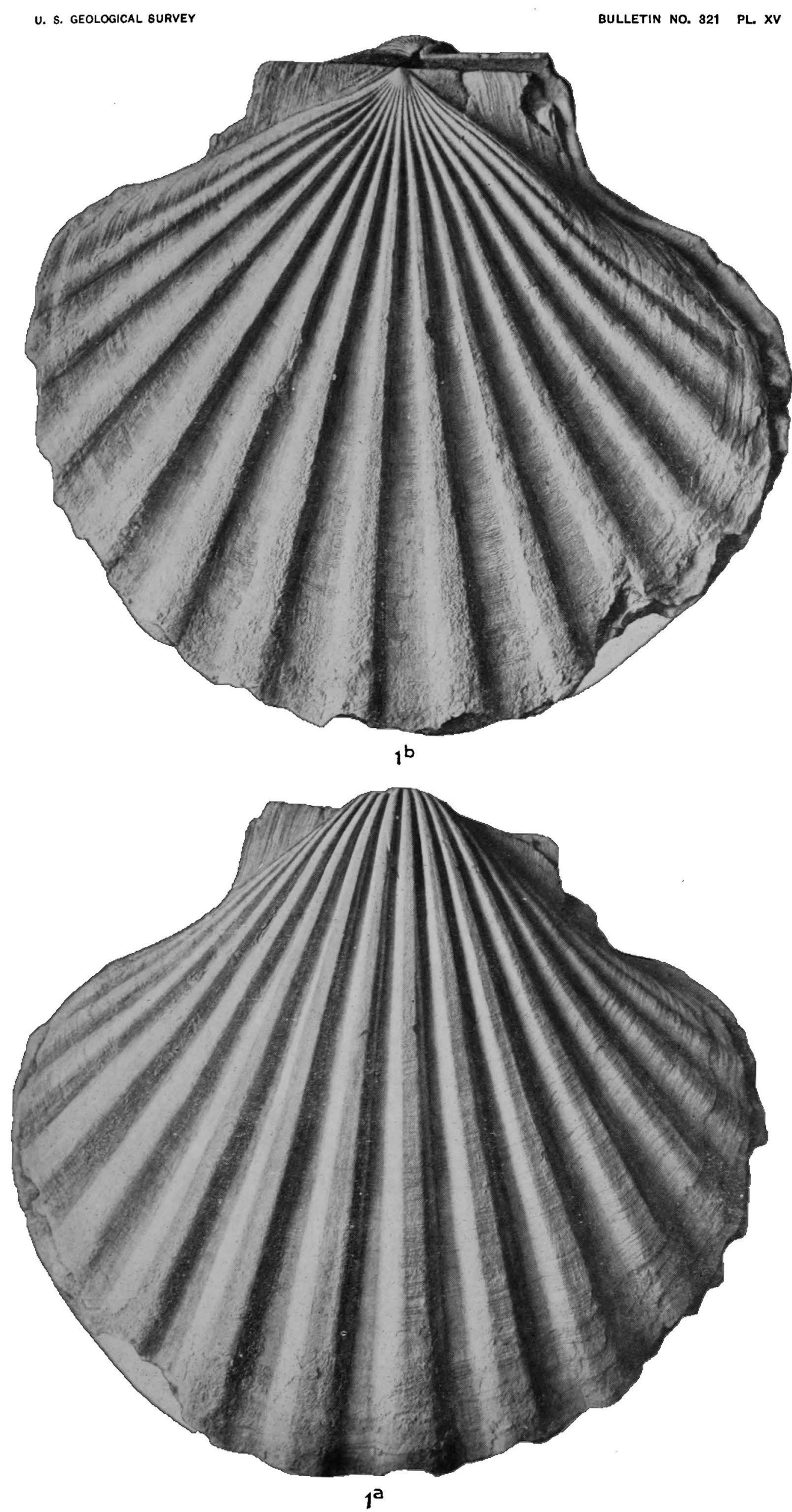

FERNANDO (PLIOCENE) PECTEN. 




\section{PLATE XVI. \\ Fernando (Pliocene) Pecten.}

(Unless otherwise indicated, all figures are natural size.)

Fig. 1a. Pecten (Patinopecten) caurinus Gould, collection of Delos Arnold. Exterior of right valve; altitude $105 \mathrm{~mm}$. Pliocene, Deadman Island, near San Pedro, Cal. Found in the upper part of the Fernando formation throughout the Coast Range.

Fra. 1b. View of left valve of same specimen.

84 

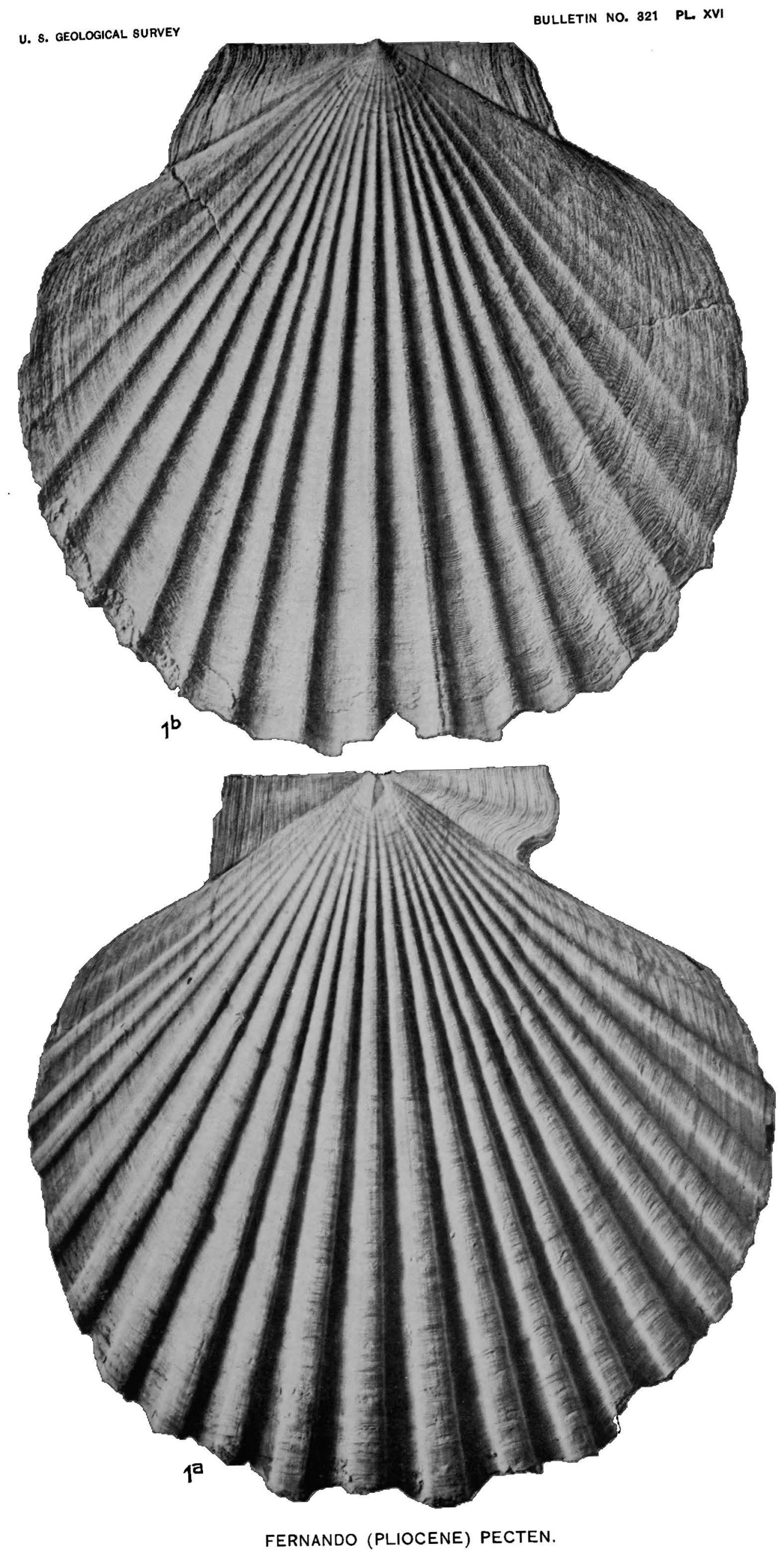




\section{PLATE XVII. \\ Fernando (Pliocene) Bryozoa.}

(Specimens figured are from Bath-house Beach, Santa Barbara.)

Frg. 1. Crisia serrata (Gabb and Horn) (Crisina id.). Front and side views of a portion of a segment, magnified. This minute bryozoan is extremely abundant in the fine washings. The lower end of each segment is pointed for articulation, while the distal extremity is blunt and receives the pointed end of the following segment.

Fig. 2. Lichenopora californica Gabb and Horn. Top, side, and basal views of an entire zoarium, magnified about four times.

Fig. 3. Semitubigera tuba Gabb and Horn. Views of zoaria, natural size; and front, side, and back views of a fragment, enlarged.

Fig. 4. Idmonea californica Conrad. Two fragments about natural size, and surface of one enlarged about eight times.

Fig. 5. Idmonea californica Conrad. Front and back views of two fragments, $\times 2$. This is the most abundant bryozoan of the Santa Barbara deposits. Most of the incrusting species figured on this plate may be found attached to the smooth back of this Idmonea.

Fig. 6. Entalophora? punctulata Gabb and Horn. Gabb and Horn's figure of Cellepora bellerophon. This species is apparently founded on the basal expansion of Entalophora punctulata.

Fig 7. Entalophora? punctulata Gabb and Horn. A fragment of a zoarium slightly reduced in size, and an enlargement of the same.

Fra. 8. Micropora dusparilis (Gabb and Horn) (Reptescharinellina). Magnified view of this incrusting species, which seems rather rare at Santa Barbara.

Fia. 9. Membranipora californica Gabb and Horn. Portion of a zoarium enlarged.

Fig. 10. Membranipora barbarensis Gabb and Horn. Several zooecia, $X 15$.

Fig. 11. Membranipora multipora (Gabb and Horn) (Siphonella id.). Surface, $\times 15$. The zoarium of this species was described by Gabb and Horn as of free tubes, but the later collections contain many specimens showing it to be parasitic in growth.

Frg. 12. Microporella californiensis (Gabb and Horn) (Cellepora id.). Celluliferous side, $\times 15$.

Frg. 13. Schizoporella cornuta (Gabb and Horn) (Reptescharellina id.). Celluliferous side of this incrusting species, $\times 15$.

Fig. 14. Lepralia eustomata (Gabb and Horn) (Reptoporina id.). Portion of surface $X$ 15 , and zoarium still further enlarged. The conspicuous pore figured by Gabb and Horn proves on study of more specimens to be merely a broken avicularium.

Fig. 15. Retepora labiata (Gabb and Horn) (Phidolopora id.). A fragment of a zoarium, about natural size, and the surface of a branch, enlarged.

Fig. 16. Cribrilina heermanni (Gabb and Horn) (Reptescharella id.). Zooecia, $\times 15$.

Fig. 17. Cribrilina? plana (Gabb and Horn) (Reptescharella id.). Second zooecia, $\times 15$.

Fia. 18. Lepralia heermanni (Gabb and Horn) (Reptescharellina id.). Surface, enlarged. This species has not been detected in the recent collections, but it is believed to be based on a form of Lepralia eustomata. (See fig. 14.) 


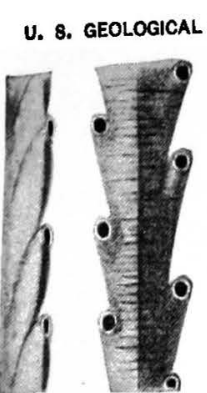

1
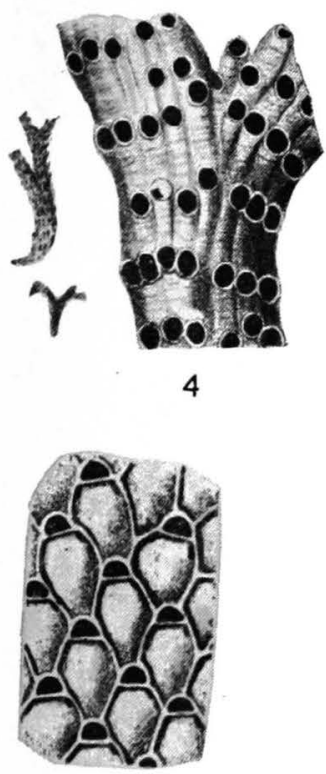

8

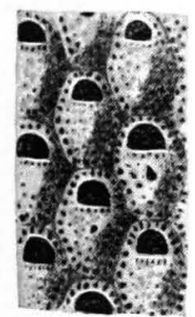

12

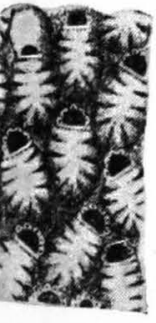

16
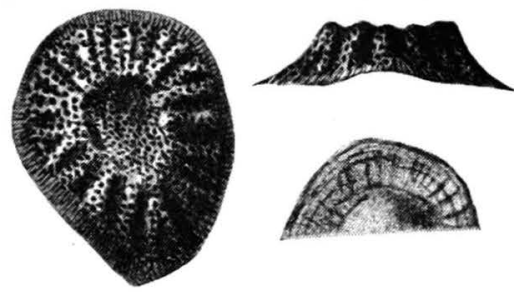

2

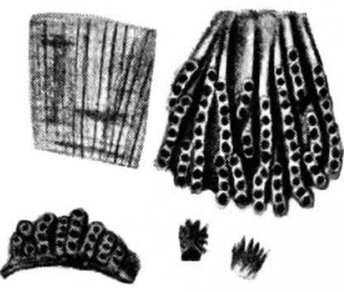

3

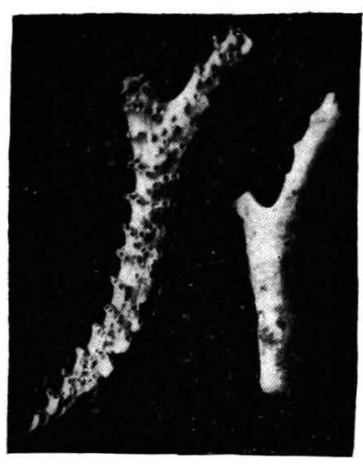

5

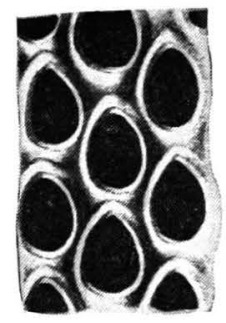

9

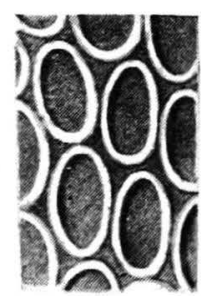

10
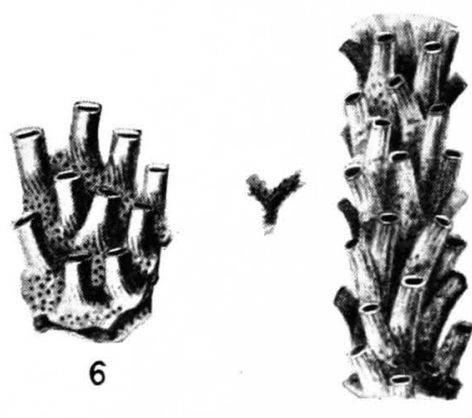

7

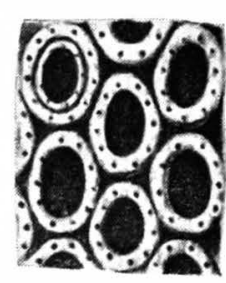

11

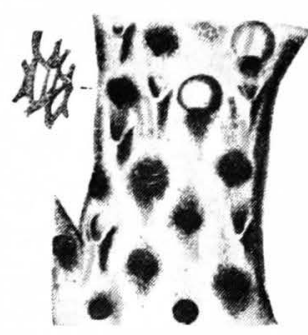

15

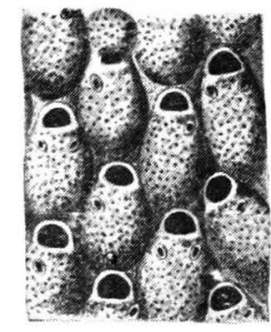

18

FERNANDO (PLIOCENE) BRYOZOA. 



\section{INDEX.}

A.

Acknowledgments to those aiding...

Acmæa insessa Hinc's, occurrence of.......

Admete gracilior Carpenter, occurrence of. .

Alameda Oil Co., oil of, analysis of...........

Amphissa corrugata Reeve, figure showing .

corrugata Reeve, occurrence of.........

Antisell, Thomas, on asphaltum deposits...

on Santa Barbara Mountains......... 9-10

Arca sp., occurrence of ................... 28

Arctic Oil Co., wells of................... $\quad 54$

Arnold, Ralph, on California oils .......... 16

on paleontology and stratigraphy at San Pedro.

work of. .

Arnold, Ralph and Delos, on geology of southern California.............

Arroyo Parida Canyon, oil seepages in...... well in.

Arroyo Parida anticline and fault, description of ........................

future development on ................

Ash, volcanic, occurrence of ................

Atmost,

Atmosphere, effect of, on gas wells ......... 50-51

Aubury, Marion, work of.

B.

Balanus concavus Bronn, occurrence of.... 32

Beach and railroad, wells between......... 41-43

Beach and wharf wells, description of..... 43-49 geology and structure in............. 43-46 logs of .............................. 45 sections of, figure showing ............ 44 yield of............................. 47

Becker wells, oil of.................... 52, 58, 59 section through, figure showing....... 38

Bela fidicula Gould, occurrence of.......... 32

Bibliography of region.................... 8-16

Bittium barbarensis Bartsch, figure showing.

barbarensis Bartsch, occurrence of ...... catalinensis Bartsch, figure showing... occurrence of.

Bituminous deposits, literature...........

Blake, W. P., on Santa Ynez Mountains.....

Bryozoa sp., occurrence of ................

Buckhorn Oil and Transportation Co., oil of, analysis of.

Building stone, occurrence of c.

Page.

California Liquid Asphalt Co., refinery of... 66

California Oil Co., wells of, oil of.......... $\quad 59$

California Oilfields Co., wells of, oil of..... $\quad 62$

Calliostoma gemmullatum Carpenter, occurrence of ...................... 32

Cardium brewerii Grbb, figure showing..... $\quad 70$

brewerii Gabb, occurrence of........... 23

corbis Martyn, figure showing ........ $\quad 32$

Carpinteria, asphalt mine near, tar volcano in, view of................... 28

beach near, view of.................. 28

folds near........................... 37

future development near............. 57

wells near ....................... 53-54, 55

Cellepora, figure showing................ 86

Chrysodomus tabulatus Baird, occurrence of ........................... 32

Clathurella conradiana Gabb, figure show-

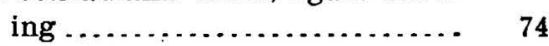

conradiana Gabb, occurrence of....... 32

Coast Range section, correlation of .......... 21

Cole well, yield of ..................... 41

Columbella (Astyris) gausapata Gould, occurrence of ................... 32

(Astyris) gausapata var. carinata Hinds, occurrence of........... 32

tuberosa Carpenter, figure showing. $\quad 74$ occurrence of ................. 32

Columbia Oil and Asphalt Co., well of...... 53-54 well of, oil of ...................... 58

Cone wells, drilling of . ................. 16

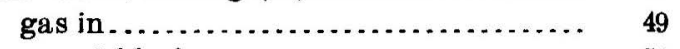
yield of ..................... 50

Crepidula adunca Sowerby, occurrence of.. $\quad 32$ navicelloides Nuttall, occurrence of..... 32

princeps Conrad, figure showing........ 78

occurrence of .................... 32

Cribrilina heermanni Gabb and Horn, figure showing...................... 86

plana Gabb and Horn, figure showing. $\quad 86$ Crisia serrata Gabb and Horn, figure showing ......................... 86

Crisina,figure showing ................... 86 Cythara branneri Arnold, occurrence of .... 32

\section{D.}

Darling Brothers, devalopment by........ 16 well of, effect of air pressure on ......... $\quad 50$ $\log$ of .......................... 50 
Darling Brothers, well of, yield of $\quad$ Page.

Davis \& Harrison, oil of, analysis of........ . 62

Development, history of................. 16-17 prospects of......................... 56-57

Disastoma sp., occurrence of .............. 32

Diatomaceous deposits, character of....... 27 distribution of........................ 27

literature of ........................... 13,27

Distillation of oils....................... 62-64

Doane, A. C., well of ...................... 49 well of, gas in, effect of air pressure on .

Doulton and Wilson wells, yield of..........

Drainage, age of.

Duquesne wells, $\log$ of oil of section through, figure showing........ water in .............................. yield of

E.

Eldridge, G. H., on aspnalt deposits 15-16 work and death of.

Entalophora punctulata Gabb and Horn, figure showing.................

Eureka Oil Co., wells of, oil of.$$
\text { F. }
$$

Fairbanks, H. W., on sonthern California geology ..................... 14-15

Fernando formation, age of .............. 31

character of.......................... 30-31

contact of Pleistocene and, view of.

distribution of ....................... 32-33

fossils of . . . . . . . . .

gas from.............................. 49

name of............................ 30

oil in ............................. 33,39,51

structure of...................... 33, 41, 43

Finch, W. W., on infusorial earth of Santa Barbara.................... 13

Fischer well, oil of . . . . . . . . . . . . . . . . . . . 53, 58

Ford, F. H., on solfataras near Santa Barbara....................... 13-14

Fossils, character and distribution of ...... 23 , $28,31-32,34 ; 54$ plates showing. $70-86$

Fusus occidentalis Gabb, figure showing ... 72 robustus Trask, occurrence of.......... 32

G.

Galerus excentricus Gabb, figure showing.. excentricus $\mathrm{Gabb}$, occurrence of......... mammilaris Broderip, figure showing... occurrence of

Gas, development of literature of occurrence of.................... 29, 40,43,49 occurrence of, mode of.

Gas wells, atmosphere and, relations of .... 50-51 description of . ....................... $49-50$ $\log$ of ............................. yield of.......................... 50-51

Geologic formations, correlation table of... 21 description of ....................... 21-35 distribution of, map showing

Glottidia albida Hinds, occurrence of....... 32
Goodyear, W. A., and Weber, A. H., on Santa Barbara oils............. Gravity of Summerland oils, range of......

$42-43,47-48,51-52,58-50$

H.

Hanks, H. G., on Carpinteria asphalt.

Heath, J., well of

Higgins, P. C., well of ...................

Home Oil Co., oil of, analysis of.............

Hot Spring Canyon, springs in............. 23-24

I.

Idmonea californica Conrad, figure showing.

Illinois Oil and Asphalt Co., well of.........

Infusorial earth. See Diatomaceous deposits.

K.

Kentuck wells, oil of, distillation of.

L.

La Cumbre Peak, elevation of

Lacuna compacta Carpenter, figure showing compacta Carpenter, occurrence of.....

Laqueus jeffreysi Dall, occurrence of........

Leda gabbi Conrad, figure showing.......... gabbi Conrad, occurrence of.............

Lepralia eustomata $\mathrm{Gabb}$ and Horn, figure showing.

heermanni Gabb and Horn, figure showing.

Leptothyra bac ing. Carpenter, figure show-

bacula Carpenter, occurrence of......... pancicostata Dall, figure showing....... occurrence of.

Lichenopora californica $\mathrm{Gabb}$ and Horn, $\mathrm{Alg}$ ure showing.

Lillis, J. C. See North Star Oil Co.

Literature, descriptive list of............... \&-16

Location of field

Lookout Park, oil well east of, $\log$ of....... oil wells west of....................... $30-10$

Loon Point, oil at and near................. 33

wells at and near. ................... 52-58

$\log$ of ........................ 58

Los Angeles, oil of, distillation of..........

Los Angeles Pacific Railway Company, oll of, analysis of.................

$\mathbf{M}$.

Macoma sp., occurrence of.

Mactra ashburneri Gabb, figure showing... ashburneri Gabb, occurrence of..........

Mangilia angulata Carpenter, occurrence of. interfossa var. pedroana Arnold, occurrence of.

tabulata Carpenter, figure showing .... occurrence of. .......................

Map, geological, of Summerland field....... Map, showing location of southern Callifornia oil districts.............. is

Maps, structural, of Summerland fleld...... 18, 30

Margarita pupilla Gould, occurrence of..... \&

\section{8 \\ 60}

63

10 74 32 32 23

58

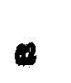


Marine Oil Co., well of, sulphur water in... Membranipora barbarensis Gabb and Horn, figure showing.

californica Gabb and Horn, figure showing.

multipora Gabb and Horn, figure showing

Mercenaria perlaminosa Conrad, figure

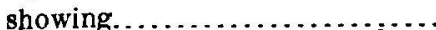
perlaminosa Conrad, occurrence of.....

Meretrix uvasana Conrad, figures showing. uvasana Conrad, occurrence of......... sp., occurrence of . ..................

Micropora disparilis Gabb and Horn, figure showing.....................

Microporella Californiensis Gabb and Horn, figure showing ......................

Miller wells, oil of ................. 52,58,59

section through, figure showing....... 38

Mission Ridge, terraces on ................ 19

Mitramorpha filosa Carpenter var. barbarensis A rnold, figure showing...

filosa Carpenter var. barbarensis Arnold occurrence of

Modiolus fornicatus Carpenter, occurrence of. occurrence of.

ontecito, diatomaceous shale near...... future development near.

well at.

Montecito anticline, description of

future development on ...............

Monterey shale, age of

distribution of ............

fossils of ........................ 28

gas from...$\ldots \ldots \ldots \ldots \ldots \ldots \ldots \ldots$

oil of ...................... 29-30,51,58

section of ........................ 28

structure of. ............... 28-29,36,37

view of.

N.

Nassa mendica Gould, occurrence of. ...... perpinguis Hinds, figure showing....... occurrence of.

Natica clausa Broderip and Sowerby, figure showing.

clausa Broderip and Sowerby, occurrence of.

North Star Oil Co., wells of, asphaltum in. wells of, oil of

sections of, figures showing.

wharf of, unconformity near, view of

Nott \& Webber well, $\log$ of ................ water in.

\section{O.}

Occidental tunnel, description of

Occidental wells, description of oil of.

water from, analysis of.

Ocean, derricks rising from drilling in, method of. occurrence of . .................. var. aspera Baird, occurrence of..... $\quad 32$ perita Hinds, occurrence of . . ........... 32

Odostomia gouldii Carpenter, occurrence of.. $\quad 32$ nuciformis var. avellana Carpenter, occurrence of ............... 32

Oil, accumulation of . . . . . . . . analyses of . . . . . . . . . . . . . . . . . . $62-64$ character of.......... 40,42-43,48,51-52,58-64 chemical properties of. . . . . . . . . . . . . . . 59-64 color of . . . . . . . . . . . . . . . . . . . distillation of . . . . . . . . . . . . . . . . . 62-64 gravity of. . . . . 40,42-43,47-48,51-52,58-59,60 literature of . . . . . . . . . . . . 12-13, 15-16 migration of . . . . . . . . . . . . . . . . . 51 price of . ........................ 17 nitrogen in . . . . . . . . . . . . . . . . . . 60,64 occurrence of, evidences of. $23,26,27,29-30,33,35$ origin of . . . . . . . . . . . 51 production of ..................... 66 cost of . . . . refining of $\ldots \ldots \ldots \ldots \ldots \ldots \ldots \ldots \ldots \ldots .66$ separation of, from sand and water... - 65 source of ......................... 29 sulphur in . . . . ..............660,62,64

Oil Canyon, tar springs in . .............. 22, 23 transportation and utilization of...... 66 wells in, description of.............. $\quad 55$

Oil companies, list of . . . . . . . . . . . . . . . . 67

Oil development, history of. ............. 16-17 technology of . ...................... 64-67

Oil districts, location of, map showing ..... 18

Oil sands, character of . . . . . . . . . . . . . . 39, 43-46 relations of, sections showing.......... 38

Oil wells, cost of . . . . . . . . . . . . . . . . . . . 64-65 description of ...................... 30-49 drilling of, in ocean, method of ........ 46 logs of ............................ 40 section through, figure showing...... 38,44 water in . . . . . . . . . . . . . . . . . . . 46,48 yield of . . . . . . . . . . . . . . . . $40,41,42,47$ Olivella biplicata Sowerby, occurrence of... 32 Ortega Hill, oil well on ................. 16 oil well on, logs of .................. 40 view from . ...................... 20

Ortegas, Arroyo de las, oil in............. 30 Ostrea idriaensis Gabb, figure showing.... 70 idriaensis $\mathrm{Gabb}$, occurrence of......... 23

Oxnard Oil Co., wells of, oil of . . . . . . . 51-52,59 wells of, sections of, figure showing. ... 38,44 yield of.

P.

Pacific Coast Oil Co., oil of, analysis of ..... Panopea generosa Gould, occurrence of.... Parida, Arroyo. See Arroyo Parida.

Peckham, S. F., on southern California oil. . 12-13 Pecten (Pecten) bellus Conrad, figure showing

82

(Pecten) bellus Conrad, occurrence of ... $\quad 32$ (Patinopecten) caurinus Gould, figure showing.

occurrence of 
Pecten (Chlamys) hastatus Sowerby, figure showing.

hastatus Sowerby, occurrence of........ var. strategus Dall, figure showing. occurrence of ..................

jordani Arnold, figure showing. ........ occurrence of....................... opuntia Dall, figure showing........... occurrence of....................... (Pseudamusium) peckhami Gabb, figure showing.

occurrence of

Petricola carditoides Conrad, occurrence of. Phacoides annulatus Reeve, occurrence of.. californica Conrad, occurrence of........ cretacea Gabb, figure showing.......... occurrence of.

sp., occurrence of................... 23, 28

Phidolopora, figure showing................

Pholadidea penita Conrad, occurrence of...

Pinal Oil Co., well of, description of........ well of, oil of.........................

Pleistocene deposits, character of

contact of Fernando and, yiew of.

distribution of.

oil in

section of, figure showing.

structure of.

view of.

Pododesmus macroschisma Deshayes, occurrence of......................

Potomac Oil Co., well of, $\log$ of well of, oil of.

oil of, analysis of ..................

Production of oil.

Protocardia centifilosa Cárpenter, occurrence of.

Prutzman, P. W., on California oils ........

Psephidia barbarensis Arnold, figure showing

barbarensis Arnold, occurrence of......

Puente district, oil of, distillation of........

Puente Oil Co., oil of.......................

Puncturella cuculata Gould, occurrence of ..

delosi Arnold, figure showing............ occurrence of

\section{R.}

Railroad, oil wells north of................. Railroad and beach, wells between.......... Refinery, location of ........................ Reptescharella, figure showing............. Reptescharinellina, figure showing......... Reptoporina, figure showing -

Retepora labiata Gabb and Horn, figure showing .

Rincon Creek, wells near.

. $53-54$

Rocks. See Geologic formations.

\section{S.}

Sand, removal of, from oil .................. Santa Barbara, oil field near structure near......................... valley of, description of age.
Santa Barbara and Naples Oil and Land Co., well of.

Santa Barbara Oil and Mining Co., wells of. wells of, gas in oil of.

Santa Clara Valley section, corralation of

Santa $\mathrm{Fe} \mathrm{Co.,} \mathrm{oil} \mathrm{of,} \mathrm{analysis} \mathrm{of}$

Santa Monica Oil Co., well of, description well of oil of

Santa Ynč Mountains, anticline of........ 36 description of.......................... 18-19 wells in . . . .......................... 55-50

Schizoporella cornuta Gabb and Horn, figure showing................... 8

Sea. Cliff Oil Co., wells of, oil of.......... 48,58,58 wells of, oil of, analysis of............. sections of, figure showing.......... 4

Seaside Oil Co., well of, $\log$ of.............

Sections, geologic, figures showing ...... 36,38,44 Semele pulchra Sowerby var. montereyi Arnold, figure showing.

pulchra Sowerby var. montereyi Arnold, occurrence of ...................

Semitubiga tuba Gabb and Horn, flgure showing.

Serena, oil near......................... 34

Sespe formation, age of ................... 25

character of ......................... 24-25

distribution of......................... 25-26

name of ........................... 24

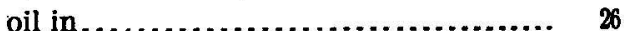

structure of. ......................... 25-26

Shepards, well at....................... 54

Siphonella, figure showing............... 86

Solfataras, literature of................. 13-14

Southern Pacific Co.'s wells. See Treadwell wells.

Spirocrypta pileum Gabb, figure showing.. 72 pileum Gabb, occurrence of............ 23

Stratigraphy. See Geologic formations.

Stroglylocentrotus purpuratus Stimson, occurrence of ................... 32

Structure, description of .................. 36-38

map showing ........................ 18,38

Summerland, structure near............. 37-38

Surumerland fault and anticline, description of........................... 38

wells on or near...................... $39-40$

Summerland section, correlation of........ 21 Summerland terrace, description of......... 20 Sycamore Canyon, diatomaceous shale near. 27

$\mathbf{T}$

Tar springs, occurrence of. $\ldots \ldots \ldots \ldots \ldots \ldots 22,28,29$

Tar volcano, view of.....................

Terehratalia hemphilli Dall, figure showing. 76 hemphilli Dall, occurrence of.......... 32

Terraces, occurrence and character of...... 19-20

Threcia sp., occurrence of................. 20 B

Topatopa formation, character of.......... 2 ?

distribution of ....................... I3

fossils of ...........................

name of .............................

oil of............................. 20,57,54

region of, future development of......

structure of ............................ 28,2

29
28
76
32
20
23
22
23
23
22
55
$5 i$
5
37
-21

\section{5} (n)

(1)

(1)

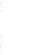

.

,

8


Page.

Topatopa formation, water in, analysis of.

Topography, description of

Toruatina culcitella Gould, figure showing. culcitella Gould, cccurrence of.

Toro Canjon, tar springs in water in, anulysis of.

wells in, description of...............

Trask, J. B., on Santa Ynez Range.

Treadwell wells, character of. section through, plate showing

Trophon (Boreotrophon) gracilis Perry, occurrence of . ..................

orpheus var. præcursor Arnold, occurrence of

stuarti Smith, figure showing.......... occurrence of...

Turbonilla tridentata Carpenter, occurrence of.

Turritella uvasana Conrad, figurc showing. urasana Conrad, occurrence of

U.

Union Oil Co., oil of, analysis of .

V.

Vaqueros formation, character of ....... 26-27 correlation of

distribution of

name of.

st ructure of

Vene icardia monilicosta Gabb, figure showing :-
Venericardia monilicosta Gabb, occurrence of ................... 32 yatesi Arnold, figure showing......... 76 occurrence of................... 32

Ventura County, oil of, distillation of..... 63

Viscosity of Summerland oils........... 59,62

Volcanic ash, occurrence of .............. 28

W.

Water, separation of oil and............ 65

Water, underground, analysis of ......... 24 occurrence of............ 23-24, 40,42,46

Watts, W. L., distillation of oil by ........ 63

Watts, W. L., on drilling in ocean

on individual wells................ 54,56

on oil and gas of region............... 15

Weber, A. H., and Goodyear, W. A., on Santa Barbara oils........... 13

Wells, description of . . . . ............... 30-51

drilling of, in ocean, method of ....... 46 logs of . . . ....................... 40 water in ......................... 46, 48 yield of ...................4 40,41, 42, 47

Wharf wells. See Beach and wharf wells.

Whitney, J. D., on bituminous deposits and geology of region. . . . . . . . . 10-12 on hot springs. .................... 24

Williams, H. L., development by ........ 16,17 well of, $\log$ of . ................... 40 oil of...................... 58,59

Wilson, J. C., wells of, oil of . ............ 59 wells of, yield of . . . . . . . . . . . . . 42-47 



\section{CLASSIPICATION OP THE PUBLICATIONS OF THE UNITED STATES GEOLOGICAL SURVEY.}

[Bulletin No. 321.]

The publications of the United States Geological Survey consist of (1) Annual Reports, (2) Monographs, (3) Professional Papers, (4) Bulletins, (5) Mineral Resources, (6) Water-Supply and Irrigation Papers, (7) Topographic Atlas of United States-folios and separate sheets thereof, (8) Geologic Atlas of United Statesfolios thereof. The classes numbered 2,7 , and 8 are sold at cost of publication; the others are distributed free. A cireular giving complete lists can be had on application.

Most of the above publications can be obtained or consulted in the following ways:

1. A limited number are delivered to the Director of the Survey, from whom they can be obtained, free of charge (except classes 2,7 , and 8), on application.

2. A certain number are delivered to Senators and Representatives in Congress for distribution.

3. Other copies are deposited with the Superintendent of Documents, Washington, D. C., from whom they can be had at prices slightly above cost.

4. Copies of all Government publications are furnished to the principal public libraries in the large cities throughout the United States, where they can be consulted by those interested.

The Professional Papers, Bulletins, and Water-Supply Papers treat of a variety of subjects, and the total number issued is large. They have therefore been classified into the following series: A, Economic geology; B, Descriptive geology; C, Systematic geology and paleontology; D, Petrography and mineralogy; E, Chemistry and physics; F, Geography; G, Miscellaneous; H, Forestry; I, Irrigation; J, Water storage; K, Pumping water; L, Quality of water; M, General hydrographic investigations; N, Water power; O, Underground waters; P, Hydrographic progress reports; Q, Fuels; R, Struetural materials. This paper is the one hundred and second in series $A$ and the one hundred and twenty-sixth in series $B$, the complete lists of which follow ( $P P=$ Professional Paper; $B=$ Bulletin; WS =Water-Supply Paper):

\section{SERIES A, ECONOMIC GEOLOGY.}

B 21. Lignites of Great Sioux Reservation: Report on region between Grand and Moreau rivers, Dakota, by Bailey Willis. 1885 . 16 pp., 5 pls. (Out of stock.)

B 46. Nature and origin of deposits of phosphate of lime, by R. A. F. Penrose, jr., with introduction by N. S. Shaler. 1888 . $143 \mathrm{pp}$. (Out of stock.)

B 65. Stratigraphy of the bituminous coal field of Pennsylvania, Ohio, and West Virginia, by I. C. White. 1891. 212 pp., 11 pls. (Out of stock.)

B 111. Geology of Big Stone Gap coal field of Virginia and Kentucky, by M. R. Campbell. 1893. 106 pp., 6 pls. (Out of stock.)

B 132. The disseminated lead ores of southeastern Missouri, by Arthur Winslow. 1896. 31 pp. (Out of stock.)

B 138. Artesian-well prospects in Atlantic Coastal Plain region, by N.H. Darton. 1896. 228 pp., 19 pls.

B 139. Geology of Castle Mountain mining district, Montana, by W. H. Weed and L. V. Pirsson. 1896. 164 pp., 17 pls.

B 143. Bibliography of clays and the ceramic arts, by J. C. Branner. 1896. 114 pp.

B 164. Reconnaissance on the Rio Grande coal fields of Texas, by T. W. Vaughan, including a report on igneous rocks from the San Carlos coal field, by E. C. E. Lord. 1900.100 pp., 11 pls. (Out of stock.)

B 178. El Paso tin deposits, by W. H. Weed. 1901. 15 pp., 1 pl. 1783-Bull. 321 $-07-7$ 
B 180. Occurrence and distribution of corundum in United States; by J. H. Pratt. $1901.98 \mathrm{pp} ., 14 \mathrm{pls}$. (Out of stock; see No. 269.)

B 182. A report on the economic geology of the Silverton quadrangle, Colorado, by F. L. Ransome. 1901. $266 \mathrm{pp} ., 16 \mathrm{pls}$. (Out of stock.)

B 184. Oil and gas fields of the western interior and northern Texas Coal Measures and of the Upper Cretaceous and Tertiary of the western Gulf coast, by G. I. Adams. 1901. 64 pp., 10 pls. (Out of stock.)

B 193. The geological relations and distribution of platinum and associated metals, by J. F. Kemp. 1902. 95 pp., 6 pls.

B 198. The Berea grit oil sand in the Cadiz quadrangle, Ohio, by W. T. Griswold. $1902.43 \mathrm{pp} ., 1 \mathrm{pl}$ (Out of stock.)

PP 1. Preliminary report on the Ketchikan mining district, Alaska, with an introductory sketch of the geology of southeastern Alaska, by A. H. Brooks. $1902.120 \mathrm{pp} ., 2 \mathrm{pls}$.

B 200. Reconnaissance of the borax deposits of Death Valley and Mohave Desert, by M. R. Campbell. 1902. $23 \mathrm{pp} ., 1 \mathrm{pl}$. (Out of stock.)

B 202. Tests for gold and silver in shales from western Kansas, by Waldemar Lindgren. 1902. 21 pp. (Out of stock.)

PP 2. Reconnaissance of the northwestern portion of Seward Peninsula, Alaska, by A. J. Collier. 1902. $70 \mathrm{pp} ., 11 \mathrm{pls}$.

PP 10. Reconnaissance from Fort Hamlin to Kotzebue Sound, Alaska, by way of Dall, Kanuti, Allen, and Kowak rivers, by W. C. Mendenhall. 1902. 68 pp., 10 pls.

PP 11. Clays of the United States east of the Mississippi River, by Heinrich Ries. 1903. 298 pp., 9 pls. (Out of stock.)

PP 12. Geology of the Globe copper district, Arizona, by F. L. Ransome. $1903.168 \mathrm{pp} ., 27 \mathrm{pls}$.

B 212. Oil fields of the Texas-Louisiana Gulf Coastal Plain, by C. W. Hayes and William Kennedy. 1903. $174 \mathrm{pp} ., 11 \mathrm{pls}$. (Out of stock.)

B 213. Contributions to economic geology, 1902; S. F. Emmons and C. W. Hayes, geologists in charge. 1903. $449 \mathrm{pp}$. (Out of stock.)

PP 15. The mineral resources of the Mount Wrangell district, Alaska, by W. C. Mendenhall and F. C. Schrader. $1903.71 \mathrm{pp} ., 10 \mathrm{pls}$.

B 218. Coal resources of the Yukon, Alaska, by A. J. Collier. $1903.71 \mathrm{pp} ., 6 \mathrm{pls}$

B 219. The ore deposits of Tonopah, Nevada (preliminary report), by J. E. Spurr. 1903.31 pp., 1 pl. (Out of stock.)

PP 20. A reconnaissance in northern Alaska in 1901, by F. C. Schrader. 1904.139 pp., 16 pls.

PP 21. Geology and ore deposits of the Bisbee quadrangle, A rizona, by F. L. Ransome. 1904.168 pp., 29 pls.

B 223. Gypsum deposits in the United States, by G. I. Adams and others. 1904. 129 pp., 21 pls. (Out of stock.)

PP 24. Zinc and lead deposits of northern Arkansas, by G. I. Adams. 1904.118 pp., 27 pls.

$\mathrm{PP} 25$. Copper deposits of the Encampment district, Wyoming, by A. C. Spencer. $1904.107 \mathrm{pp}$, 2 pls. (Out of stock.)

B 225. Contributions to economic geology, 1903, by S. F. Emmons and C. W. Hayes, geologists in charge. 1904. 527 pp., 1 pl. (Out of stock.)

PP 26. Economic resources of the northern Black Hills, by J. D. Irving, with contributions by S. F. Emmons and T. A. Jaggar, jr. 1904. 222 pp., 20 pls.

PP 27. A geological reconnaissance across the Bitterroot Range and Clearwater Mountains in Montana and Idaho, by Waldemar Lindgren. 1904. 123 pp., 15 pls.

B 229. Tin deposits of the York region, Alaska, by A. J. Collier. $1904.61 \mathrm{pp} ., 7 \mathrm{pls.}$

B 236. The Porcupine placer district, Alaska, by C. W. Wright. 1904.35 pp., 10 pls.

B 238. Economic geology of the Iola quadrangle, Kansas, by G. I. Adams, Erasmus Haworth, and W. R. Crane. 1904. 83 pp., 11 pls.

B 243. Cement materials and industry of the United States, by E. C. Eckel. 1905.395 pp., 15 pls.

B 246. Zinc and lead deposits of northwestern Illinois, by H. Foster Bain. 1904.56 pp., 5 pls.

B 247. The Fairhaven gold placers of Seward Peninsula, Alaska, by F. H. Moffit. 1905.85 pp., 14 pls.

B 249. Limestones of southeastern Pennsylvania, by F. G. Clapp. 1905.52 pp., 7 pls.

B 250. The petroleum fields of the Pacific coast of Alaska, with an account of the Bering River coal deposits, by G. C. Martin. 1905. 65 pp., 7 pls.

B 251. The gold placers of the Fortymile, Birch Creek, and Fairbanks regions, Alaska, by L. M. Prindle. $1905.89 \mathrm{pp} ., 16 \mathrm{pls}$.

WS 117. The lignite of North Dakota and its relation to irrigation, by F. A. Wilder. $1905.59 \mathrm{pp} . .8 \mathrm{pls}$. PP 36. The lead, zinc, and fluorspar deposits of western Kentucky, by E. O. Ulrich and W. S. T. Smith. 1905. $218 \mathrm{pp} ., 15 \mathrm{pls}$.

PP 38. Economic geology of the Bingham mining district, Utah, by J. M. Boutwell, with a chapter on areal geology, by Arthur Keith, and an introduction on general geology, by S. F. Emmons. 1905. $413 \mathrm{pp} .49 \mathrm{pls}$

PP 41. Geology of the central Copper River region, Alaska, by W. C. Mendenhall. $1905.133 \mathrm{pp} . .20$ pils. B 254. Report of progress in the geological resurvey of the ('ripple Creek district, ('olorado, by Wuldrmar Lindgren and F L. Ransome. 1904. $36 \mathrm{pp}$. 
B 255. The fluorspar deposits of southern Illinois, by H. Foster Bain. 1905. 75 pp., 6 ple. (Out of stock.)

B 256. Mineral resources of the Elders Ridge quadrangle, Pennsylvania, g R. W. Stone. 1905. 86 pp., 12 pls.

B 259. Report on progress of investigations of mineral resources of Alaska in 1904, by A. H. Brooks and others. $1905.196 \mathrm{pp} ., 3 \mathrm{pls}$.

B 260. Contributions to economic geology, 1904; S. F. Emmons and C. W. Hayes, geologists in charge. $1905.620 \mathrm{pp} ., 4 \mathrm{pls}$.

B 261. Preliminary report on the operations of the coal-testing plant of the United States Geological Survey at the Louisiana Purchase Exposition, St. Louis, Mo., 1904; E. W. Parker, J. A. Holmes, and M. R. Campbell, committee in charge. 1905 . $172 \mathrm{pp.} \mathrm{(Out} \mathrm{of} \mathrm{stock.)}$

B 263. Methods and cost of gravel and placer mining in Alaska, by C. W. Purington. 1905.273 pp., 42 pls. (Out of stock.)

PP 42. Geology of the Tonopah mining district, Nevada, by J. È. Spurr. 1905.295 pp., 24 pls.

PP 43. The copper deposits of the Clifton-Morenci district, Arizona, by Waldemar Lindgren. 1905. 375 pp., 25 pls.

B 264. Record of deep-well drilling for 1904, by M. L. Fuller, E. F. Lines, and A. C. Veatch. 1905. $106 \mathrm{pp}$.

B 265. Geology of the Boulder district, Colorado, by N. M. Fenneman. $1905.101 \mathrm{pp} ., 5 \mathrm{pls}$.

B 267. The copper deposits of Missouri, by H. Foster Bain and E. O. Ulrich. $1905.52 \mathrm{pp} ., 1 \mathrm{pl}$.

B 269. Corundum and its occurrence and distribution in the United States (a revised and enlarged edition of Bulletin No. 180), by J. H. Pratt. 1906. 175 pp., 18 pls.

PP 48. Report on the operations of the coal-testing plant of the United States Geological Survey at the Louisiana Purchase Exposition, St. Louis, Mo., 1904; E. W. Parker, J. A. Holmes, M. R. Campbell, committee in charge. 1906. (In three parts.) 1,492 pp., 13 pls.

B 275. Slate deposits and slate industry of the United States, by T. N. Dale, with sections by E. C. Eckel, W. F. Hillebrand, and A. T. Coons. 1906. $154 \mathrm{pp} ., 25 \mathrm{pls}$.

PP 49. Geology and mineral resources of part of the Cumberland Gap coal field, Kentucky, by G. H. Ashley and L. C. Glenn, in cooperation with the State Geological Department of Kentucky, C. J. Norwood, curator. 1906.239 pp., 40 pls.

B 277. Mineral resources of Kenai Peninsula, Alaska: Gold fields of the Turnagain Arm region, by F. H. Moffit. Coal fields of the Kachemak Bay region, by R. W. Stone. 1906.80 pp., 18 pls,

B 278. Geology and coal resources of the Cape Lisburne region, Alaska, by A.J.Collier. 1906. 54 pp., 9 pls. (Out of stock.)

B 279. Mineral resources of the Kittanning and Rural Valley quadrangles, Pennsylvania, by Charles Butts. 1906. 193 pp., 11 pls.

B 280. The Rampart gold placer region, Alaska, by L. M. Prindle and F. L. Hess. 1906.54 pp., 7 pls. (Out of stock.)

B 282. Oil fields of the Texas-Louisiana Gulf Coastal Plain, by N. M. Fenneman. 1906.146 pp., 11 pls.

PP 51. Geology of the Bighorn Mountains, by N. H. Darton. 1906.129 pp., 47 pls.

B 283. Geology and mineral resources of Mississippi, by A. F. Crider. 1906.99 pp., 4 pls.

B 284. Report on progress of investigations of the mineral resources of Alaska in 1905, by A. H. Brooks and others. 1906. $169 \mathrm{pp} ., 14 \mathrm{pls}$.

B 285. Contributions to economic geology, 1905; S. F. Emmons and E. C. Eckel, geologists in charge. 1906. $506 \mathrm{pp} ., 13 \mathrm{pls}$. (Out of stock.)

B 286. Economic geology of the Beaver quadrangle, Pennsylvania, by L. H. Woolsey. 1906.132 pp., $8 \mathrm{pls}$.

B 287. Juneau gold belt, Alaska, by A. C. Spencer, and A reconnaissance of Admiralty Island, Alaska, by C. W. Wright. 1906.161 pp.. 27 pls.

PP 54. The geology and gold deposits of the Cripple Creek district, Colorado, by W. Lindgren and F. L. Ransome. 1906.516 pp., 29 pls.

PP 55. Ore deposits of the Silver Peak quadrangle. Nevada, by J. E. Spurr. 1906.174 pp., 24 pls.

B 289. A reconnaissance of the Matanuska coal field, Alaska, in 1905, by G. C. Martin. 1906. 34 pp., 5 pls.

B 290. Preliminary report on the operations of the fuel-testing plant of the United States Geological Survey at St. Louis, Mo., 1905, by J. A. Holmes. 1906. 240 pp.

B 293. Reconnaissance of some gold and tin deposits of the southern Appalachians, by L. C. Graton, with notes on the Dablonega mines, by W. Lindgren. $1906.134 \mathrm{pp} ., 9 \mathrm{pls}$.

B 294. Zinc and lead deposits of the upper Mississippi Valley, by H. Foster Bain. 1906.155 pp., 16 pls. B 295. The Yukon-Tanana region, Alaska, description of Circle quadrangle, by L. M. Prindle. 1906. $27 \mathrm{pp} ., 1 \mathrm{pl}$.

B 296. Economic geology of the Independence quadrangle, Kansas, by Frank C. Schrader and Erasmus Haworth. 1906.74 pp., 6 pls.

B 297. The Yampa coal field, Routt County, Colo., by N. M. Fenneman, Hoyt S. Gale, and M. R. Campbell. 1906. 96 pp., 9 pls.

B 298. Record of deep-well drilling for 1905, by Myron L. Fuller and Samuel Sanford. 1906. 299 pp.

B 300. Economic geology of the Amity quadrangle in eastern Washington County, Pa., by Frederick G. Clapp. 1907. 145 pp., 8 pls. 
B 308. Preliminary account of Golafield, Bullfrog, and other mining districts in southern Nevada, by F. L. Ransome, with notes on the Manhattan district, by G. H. Garrey and W. H. Emmons. 1906. 98 pp., 5 pls.

B 304. Oil and gas fields of Greene County, Pa., by Ralph W.Stone and Frederick G.Clapp. 1906. 110 pp., 3 pls.

PP 56. Geography and geology of a portion of southwestern Wyoming, with special reference to coal and oil, by A. C. Veatch. 1907. 178 pp., 26 pls.

B 308. A geologic reconnaissance in southwestern Nevada and eastern California, by S. H. Ball. 1907. 218 pp., 3 pls.

B 309. The Santa Clara Valley, Puente Hills, and Los Angeles oil districts, southem California, by G. H. Eldridge and Ralph Arnold. 1907. 266 pp., 41 pls.

B 312. The interaction between minerals and water solutions, with special reference to geologic phenomena, by E. C. Sullivan. 1907 . 69 pp.

B 313. The granites of Maine, by T. Nelson Dale, with an introduction by G. O. Smith. 1907. 202 pp., 14 pls.

B 314. Report of progress of investigations of mineral resources of Alaska in 1906, by A. H. Brooks and others. 1907. $235 \mathrm{pp}$., 4 pls.

B 315. Contributions to economic geology, 1906, Part I: Metals and nonmetals, except fuels; S. F. Emmons and E. C. Eckel, geologists in charge. 1907. 504 pp., 4 pls.

WS 215. Geology and water resources of a portion of the Missouri River Valley in northeastern Nebraska, by G. E. Condra. 1908 . - pp., 11 pls.

WS 216. Geology and water resources of the Republican River Valley in Nebraska and adjacent areas, by G. E. Condra. 1907. 71 pp., 13 pls.

B 316. Contributions to economic geology, 1906, Part II: Coal, lignite, and peat. M. R. Campbell, geologist in charge. 1907. - pp., 23 pls.

B 317. Preliminary report on the Santa Maria oil district, Santa Barbara County, Cal., by Ralph Arnold and Robert Anderson. 1907. 69 pp., 2 pls.

B 318. Geology of oil and gas fields in Steubenville, Burgettstown, and Claysville quadrangles, Ohio, West Virginia, and Pennsylvania, by W. T. Griswold and M. J. Munn. 1907. 196 pp., 13 pls.

B 320. The Downtown district of Leadville, Colo., by S. F. Emmons and J. D. Irving. 1907.75 pp., 7 pls.

B 321. Geology and oil resources of the Summerland district, Santa Barbara County, Cal., by Ralph Arnold. 1907. 91 pp., 20 pls.

\section{SERIES B, DESCRIPTIVE GEOLOGY.}

B.23. Observations on the junction between the Eastern sandstone and the Keweenaw series on Keweenaw Point, Lake Superior, by R. D. Irving and T. C. Chamberlin. 1885. 124 pp., 17 pls. (Out of stock.)

B 33. Notes on geology of northern California, by J. S. Diller. 1886.23 pp. (Out of stock.)

B 39. The upper beaches and deltas of Glacial Lake Agassiz, by Warren Upham. 1887. 84 pp., 1 pl. (Out of stock.)

B 40. Changes in river courses in Washington Territory due to glaciation, by Bailey Willis. 1887. 10 pp., 4 pls. (Out of stock.)

B 45. The present condition of knowledge of the geology of Texas, by R. T. Hill. 1887.94 pp. (Ont of stock.)

B 53. The geology of Nantucket, by N. S. Shaler. 1889.55 pp., 10 pls. (Out of stock.)

B 57. A geological reconnaissance in southwestern Kansas, by Robert Hay. 1890.49 pp., 2 pls.

B 58. The glacial boundary in western Pennsylvania, Ohio, Kentucky, Indiana, and Illinois, by G. F. Wright, with introduction by T. C. Chamberlin. 1890. 112 pp., 8 pls. (Out of stock.)

B 67. The relations of the traps of the Newark system in the New Jersey region, by N. H. Darton. 1890. $82 \mathrm{pp}$. (Out of stock.)

B 104. Glaciation of the Yellowstone Valley north of the Park, by W. H. Weed. 1893.41 pp., 4 pls.

B 108. A geological reconnaissance in central Washington, by I. C. Russell. 1893.108 pp.; 12 pls. (Out of stock.)

B 119. A geological reconnaissance in northwest Wyoming, by G. H. Eldridge. 1894.72 pp., 4 pls.

B 137. The geology of the Fort Riley Military Reservation and vicinity, Kansas, by Robert Hay. 1896. 35 pp., 8 pls.

B 144. The moraines of the Missouri Coteau and their attendant deposits, by J. E. Todd. 1896. 7 pp., 21 pls.

B 158. The moraines of southeastern South Dakota and their attendant deposits, by J. E. Todd. 1899. 171 pp., 27 pls.

B 159. The geology of eastern Berkshire County, Massachusetts, by B. K. Fimerson. 1899. 139 pp., 9 pls.

B 165. Contributions to the geology of Maine, by H. S. Williams and H. E. Gregory. 1900. 212 pp., $14 \mathrm{pls}$.

Ws 70. Geology and water resources of the Patrick and Gosheu Hole quadrangles in eastern Wyoming and western Nebraska, by G. I. Adams. 1902.50 pp., 11 pls. 
B 199. Geology and water resources of the Snake River Plains of Idaho, by I. C. Russell. $1902.192 \mathrm{pp.}$ 25 pls.

PP 1. Preliminary report on the Ketchikan mining district, Alaska, with an introductory sketch of the geology of southeastern Alaska, by A. H. Brooks. 1902.120 pp., 2 pls.

PP 2. Reconnaissance of the northwestern portion of Seward Peninsula,Alaska, by A. J. Collier. 1902. 70 pp., 11 pls.

PP 3. 'Geology and petrography of Grater Lake National Park, by J. S. Diller and H. B. Patton. 1902. 167 pp., 19 pls.

PP 10. Reconnaissance from Fort Hamlin to Kotzebue Sound, Alaska, by way of Dall, Kanuti, Allen, and Kowak rivers, by W. C. Mendenhall. 1902.68 pp., $10 \mathrm{pls}$.

PP 11. Clays of the United States east of the Mississippi River, by Heinrich Ries. 1903. 298 pp., 9 pls, (Out of stock.)

PP 12. Geology of the Globe copper district, Arizona, by F. L. Ransome. 1903.168 pp., 27 pls.

PP 13. Drainage modifications in southeastern Ohio and adjacent parts of West Virginia and Kentucky, by W. G. Tight. 1903. 111 pp., 17 pls. (Out of stock.)

B 208. Descriptive geology of Nevada south of the fortieth parallel and adjacent portions of California, by J. E. Spurr. 1903. 229 pp., 8 pls. (Out of stock.)

B 209. Geology of Ascutney Mountain, Vermont, by R. A. Daly. 1903.122 pp., 7 pls.

WS 78. Preliminary report on artesian basins in southwestern Idaho and southeastern Oregon, by I. C. Russell. 1903 , 51 pp., 2 pls.

PP 15. Mineral resources of the Mount Wrangell district, Alaska, by W. C. Mendenhall and F. C. Schrader. $1903.71 \mathrm{pp} ., 10 \mathrm{pls}$.

PP 17. Preliminary report on the geology and water resources of Nebraska west of the one hundred and third meridian, by N. H. Darton. $1903.69 \mathrm{pp} ., 43 \mathrm{pls}$.

B 217. Notes on the geology of southwestern Idaho and southeastern Oregon, by I. C. Russell. 1903. $83 \mathrm{pp} ., 18 \mathrm{pls}$.

B 219. The ore deposits of Tonopah, Nevada (preliminary report), by J. E. Spurr. $1903 . \quad 31$ pp., 1 pl. PP 20. A reconnaissance in northern Alaska in 1901, by F. C. Schrader, 1904.139 pp., 16 pls.

PP 21. The geology and ore deposits of the Bisbee quadrangle, Arizona, by F. L. Ransome. 1904.168 pp., 29 pls.

WS 90. Geology and water resources of part of the lower James River Valley, South Dakota, by J.F. Todd and C. M. Hall. $1904.47 \mathrm{pp} ., 23 \mathrm{pls}$.

PP 25. The copper deposits of the Encampment district, Wyoming, by A. C. Spencer. 1904.107 pp., 2 pls. (Out of stock.)

PP 26. Economic resources of the northern Black Hills, by J. D. Irving, with contributions by S. F. Emmons and T. A. Jaggar, jr. 1904. 222 pp., 20 pls.

PP 27. A geological reconnaissance across the Bitterroot Range and Clearwater Mountains in Montana and Idaho, by Waldemar Lindgren. $1904.122 \mathrm{pp} ., 15 \mathrm{pls}$.

PP 31. Preliminary report on the geology of the Arbuckle and Wichita mountains in Indian Territory and Oklahoma, by J. A. Taff, with an appendix on reported ore deposits in the Wichita Mountains, by H. F. Bain. 1904. 97 pp., 8 pls.

B 235. A geological reconnaissance across the Cascade Range near the forty-ninth parallel, by G. 0 . Smith and F. C. Calkins. 1904.103 pp., 4 pls.

B 236. The Porcupine placer district, Aiaska, by C. W. Wright. 1904.35 pp., 10 pls.

B 237. Igneous rocks of the Highwood Mountains, Montana, by L. V. Pirsson. 1904.208 pp., 7 pls.

B 238. Economic geology of the Iola quadrangle, Kansas, by G. I. Adams, Erasmus Haworth, and W. R. Crane. 1901. 83 pp., 1 pl.

PP 32. Geology and underground water resources of the central Great Plains, by N.H. Darton. 1905. $433 \mathrm{pp} ., 72 \mathrm{pls}$.

WS 110. Contributions to hydrology of eastern United States, 1904; M. L. Fuller, geologist in charge, 1905. 211 pp., 5 pls.

B 242. Geology of the Hudson Valley between the Hoosic and the Kinderhook, by T. Nelson Dale, 1904. 63 pp., 3 pls.

PP 34. The Delavan lobe of the Lake Michigan glacier of the Wisconsin stage of glaciation and associated phenomena, by W. C. Alden. $1904.106 \mathrm{pp}$., $15 \mathrm{pls}$.

PP 35. Geology of the Perry Basin in southeastern Maine, by G. O. Smith and David White. 1905. 107 pp., 6 pls.

B 243. Cement materials and industry of the United States, by E. C. Eckel. 1905.395 pp., 15 pls,

B 246. Zinc and lead deposits of northeastern Illinois, by H. F. Bain. 1904 . 56 pp., 5 pls.

B 247. The Fairhaven gold placers of Seward Peninsula, Alaska, by F. H. Moffit. 1905. 85 pp., 14 pls.

B 249. Limestones of southwestern Pennsylvania, by F. G. Clapp. 1905.62 pp., 7 pls.

B 250. The petroleum fields of the Pacific coast of Alaska, with an account of the Bering River coal deposit, by G. C. Martin. 1905. 65 pp., 7 pls.

B 251. The gold placers of the Fortymile, Birch Creek, and Fairbanks regions, Alaska, by L. M. Prindle. 1905. $16 \mathrm{pp} ., 16 \mathrm{pls}$.

W8 118. Geology and water resources of a portion of east-central Washimgton, by F. C. Calkins. 1905. 96 pp., 4 pls.

B 252. Preliminary report on the geology and water resources of central Oregon, by I. C. Russell. 1905. . 138 pp., 24 pls. 
PP 36. The lead, zinc, and fluorspar deposits of western Kentucky, by E. O. Ulrich and W.S. Tangier Smith. 1905. $218 \mathrm{pp}$, $15 \mathrm{pls}$.

PP 38. Economic geology of the Bingham mining district of Utah, by J. M. Boutwell, with a chapter on areal geology, by Arthur Keith, and an introduction on general geology, by \$. F. Emmons. 1905. $413 \mathrm{pp}$., 49 pls.

PP 41. The geology of the central Copper River region, Alaska, by W. C. Mendenhall. $1905.133 \mathrm{pp}$, 20 pls.

B 254. Report of progress in the geological resurvey of the Cripple Creek district, Colorado, by Waldemar Lindgren and F. L. Ransome. $1904.36 \mathrm{pp}$.

B 255. The fluorspar deposits of southern Illinois, by H. Foster Bain. 1905. 75 pp., 6 pls. (Out of stock.)

B 256. Mineral resources of the Elders Ridge quadrangle, Pennsylvania, by R. W. Stone. 1905.85 pp., 12 pls.

B 257. Geology and paleontology of the Judith River beds, by T. W. Stanton and J. B. Hatcher, with a chapter on the fossil plants, by F. H. Knowlton. 1905.174 pp., 19 pls.

PP 42. Geology of the Tonopah mining district, Nevada, by J. E. Spurr. 1905.295 pp., 24 pls.

WS 123. Geology and underground water conditions of the Jornada del Muerto, New Mexico, by C. R. Keyes. 1905.42 pp., 9 pls. (Out of stock.)

WS 136. Underground waters of Salt River Valley, Arizona, by W. T. Lee. 1905.194 pp., 24 pls.

PP .43. The copper deposits of Clifton-Morenci, Arizona, by Waldemar Lindgren. 1905.375 pp., 25 pls.

B 265. Geology of the Boulder district, Colorado, by N. M. Fenneman. $1905.101 \mathrm{pp} ., 5 \mathrm{pls}$.

B 267. The copper deposits of Missouri, by H. F. Bain and E. O. Ulrich. $1905.52 \mathrm{pp} ., 1 \mathrm{pl}$.

PP 44. Underground water resources of Long Island, New York, by A. C. Veatch and others. 1905. 394 pp., 34 pls.

WS 148. Geology and water resources of Oklahoma, by C. N. Gould. 1905.178 pp., 22 pls.

B 270. The configuration of the rock floor of Greater New York, by W. H. Hobbs. 1905.96 pp., 5 pls.

B 272. Taconic physiography, by T. M. Dale. 1905.52 pp., 14 pls.

PP 45. The geography and geology of Alaska, a summary of existing knowledge, by A. H. Brooks, with a section on climate, by Cleveland $\mathrm{Abbe}$, jr., and a topographic map and description thereof, by R. M. Goode. 1905.327 pp., 34 pls.

B 273. The drumlins of southeastern Wisconsin (preliminary paper), by W. C. Alden. 1905. 46 pp., 9 pls.

PP 46. Geology and underground water resources of northern Louisiana and southern Arkansas, by A. C. Veatch. 1906. $422 \mathrm{pp}$., $51 \mathrm{pls.}$

PP 49. Geology and mineral resources of part of the Cumberland Gap coal field, Kentucky, by G. H. A shley and L. C. Glenn, in cooperation with the State Geological Department of Kentucky, C. J. Norwood, curator. 1906.239 pp., 40 pls.

PP 50. The Montana lobe of the Keewatin ice sheet, by F. H. H. Calhoun. 1906.62 pp., 7 pls.

B 277. Mineral resources of Kenai peninsula, Alaska: Gold fields of the Turnagain Arm region, by F. H. Moffit; and the coal fields of the Kachemak Bay region, by R. W. Stone. 1906.80 pp., 18 pls. (Out of stock.)

WS 154. The geology and water resources of the eastern portion of the Panhandle of Texas, by C. N. Gould. $1906.64 \mathrm{pp} ., 15 \mathrm{pls}$.

B 278. Geology and coal resources of the Cape Lisburne region, Alaska, by A. J. Collier. 1906. 54 pp., 9 pls. (Out of stock.)

B 279. Mineral resources of the Kittanning and Rural Valley quadrangles, Pennsylvania, by Charles Butts. $1906.198 \mathrm{pp} ., 11 \mathrm{pls}$.

B 280. The Rampart gold placer region, Alaska, by L. M. Prindle and F. L. Hess. 1906.54 pp., 7 pls. (Out of stock.)

B 282. Oil fields of the Texas-Louisiana Gulf Coastal Plain, by N. M. Fenneman. 1906.146 pp., 11 pls. WS 157. Underground water in the valleys of Utah Lake and Jordan River, Utah, by G. B. Richardson. 1906.81 pp., 9 pls.

PP 51. Geology of the Bighorn Mountains, by N. H. Darton. 1906.129 pp., 47 pls.

WS 158. Preliminary report on the geology and underground waters of the Roswell artesian area, New Mexico, by C. A. Fisher. 1906. 29 pp., 9 pls.

PP 52. Geology and underground waters of the Arkansas Valley in eastern Colorado, by N. H. Darton. 1906. $90 \mathrm{pp} ., 28 \mathrm{pls}$.

WS 159. Summary of underground-water resources of Mississippi, by A. F. Crider and L. C. Johnson. 1906. 86 pp., 6 pls.

PP 53. Geology and water resources of the Bighorn basin, Wyoming, by C. A. Fisher. 1906. 72 pp. 16 pls.

B 283. Geology and mineral resources of Mississippi, by A. F. Crider. 1906.99 pp., 4 pls.

B 286. Economic geology of the Beaver quadrangle, Pennsylvania (southern Beaver and northwestern Allegheny counties), by L. H. Woolsey. $1906.132 \mathrm{pp} ., 8 \mathrm{pls}$.

B 287. The Juneau gold belt, Alaska, by A. C. Spencer, and a reconnaissance of Admiralty Island, Alaska, by C. W. Wright. $1906.161 \mathrm{pp} ., 37 \mathrm{pls}$.

PP 54. The geology and gold deposits of the Cripple Creek district, Colorado, by W. Lindgren and F. L. Runsome. 1906.516 pp., 29 pls. 
PP 55. Ore deposits of the Silver Peak quadrangle, Nevada, by J. E. Spurr. 1906. 174 pp., 24 pls. B 289. A reconnaissance of the Matanuska coal field, Alaska, in 1905, by G. C. Martin. 1906.36 pp., 5 pls.

Ws 164. Underground waters of Tennessee and Kentucky west of Tennessee River and of an adjacent area in Illinois, by L. C. Glenn. $1906.173 \mathrm{pp} ., 7 \mathrm{pls.}$

B 293. Reconnaissance of some gold and tin depasits of the southern Appalachians, by L. C. Groton, with notes on the Dahlonega mines, by W. Lindgren. 1906.134 pp., 9 pls.

B 294. Zinc and lead deposits of the upper Mississippi Valley, by H. Foster Bain. $1906.155 \mathrm{pp} ., 16$ pls.

B 295. The Y'ukon-Tanana region, Alaska, description of Circle quadrangle, by L. M. Prindle. 1906. 27 pp., 1 pl.

B 296. Economic geology of the Independence quadrangle, Kansas, by Frank C. Schrader and Erasmus Haworth. 1906.74 pp., 6 pls.

W8 181. Geology and water resources of Owens Valley, California, by Willis T. Lee. 1906. 28 pp., 6 pls.

B 297. The Yampa coal field, Routt County, Colo., by N. M. Fenneman, Hoyt S. Gale, and M. R. Campbell. 1906. 96 pp., 9 pls.

B 300. Economic geology of the Amity quadrangle in eastern Washington County, Pa., by F. G. Clapp. 1906.145 pp., 8 pls.

B 303. Preliminary account of Goldfield, Bullfrog, and other mining districts in southern Nevada, by F. L. Ransome; with notes on Manhattan district, by G. H. Garrey and W. H. Emmons. 1907. 98 pp., 5 pls.

B 304. Oil and gas fields of Greene County, Pa., by R. W. Stone and F. G. Clapp. 1907.110 pp., 3 pls. WS 188. Water resources of the Rio Grande Valley in New Mexico and their development, by W. T. Lee. $1906.59 \mathrm{pp}$.; $10 \mathrm{pls}$.

B 306. Rate of recession of Niagara Falls, accompanied by a report on the survey of the crest, by W. Carvel Hall. 1906.31 pp., 11 pls.

PP 56. Geography and geology of a portion of southwestern Wyoming, with special reference to coal and oil, by A. C. Veatch. $1907.178 \mathrm{pp} ., 26 \mathrm{pls}$.

B 308. A geologic reconnaissance in southwestern Nevada and eastern California, by S. H. Ball. 1907. $218 \mathrm{pp} ., 3 \mathrm{pls}$.

B 309. The Santa Clara Valley, Puente Hills, and Los Angeles oil districts, southern California, by G. H. Eldridge and Ralph Arnold. 1907. $266 \mathrm{pp} ., 41 \mathrm{pls.}$

PP 57. Geology of the Marysville mining district, Montana, a study of igneous intrusion and contact metamorphism, by Joseph Barrell. 1907. 178 pp., 16 pls.

WS 191. The geology and water resources of the western portion of the Panhandle of Texas, by C. N. Gould. 1907. 70 pp., 7 pls.

B 311. The green schists and associated granites and porphyries of Rhode Island, by B. K. Emerson and J. H. Perry. 1907. 74 pp., 2 pls.

W8 195. Underground waters of Missouri, their geology and utilization, by Edward Shepard. 1907. $224 \mathrm{pp} ., 6 \mathrm{pls}$.

WS 199. Underground water in Sanpete and central Sevier valleys, Utah, by G. B. Richardson. 1907. $63 \mathrm{pp} ., 6 \mathrm{pls}$.

WS 215. Geology and water resources of a portion of the Missouri River Valley in northeastern Nebraska, by G. E. Condra. 1908. - pp., 11 pls.

WS 216. Geology and water resources of the Republican River Valley in Nebraska and adjacent areas, by G. E. Condra. 1907.71 pp., 13 pls.

B 817. Preliminary report on the Santa Maria Oil district, Santa Barbara County, Cal., by Ralph Arnold and Robert Anderson. 1907. 69 pp., 2 pls.

B 318. Geology of Oil and gas fields in Steubenville, Burgettstown, and Claysville quadrangles, Ohio, West Virginia, and Pennsylvania, by W. T. Griswold and M.J.Munn. 1907. $196 \mathrm{pp} ., 13 \mathrm{pls}$

B 319. Summary of controlling factors of artesian flows, by M. L. Fuller. 1908. - pp., 7 pls.

B 320. The Downtown district of Leadville, Colo,, by S. F. Emmons and J. D. Irving. 1907.75 pp.,
7 pls. B 321. Geology and oil resources of the Summerland district, Santa Barbara County, Cal., by Ralph
Arnold. 1907.91 pp., 20 pls.

Correspondence should be addressed to

The Director,

September, $190 \%$.

United States Geological Survey, W Ashington, D. C. 

